\title{
AGC-2 Irradiation Report
}

David Rohrbaugh

William Windes

W. David Swank

June 2016

The INL is a

U.S. Department of Energy

National Laboratory

operated by

Battelle Energy Alliance

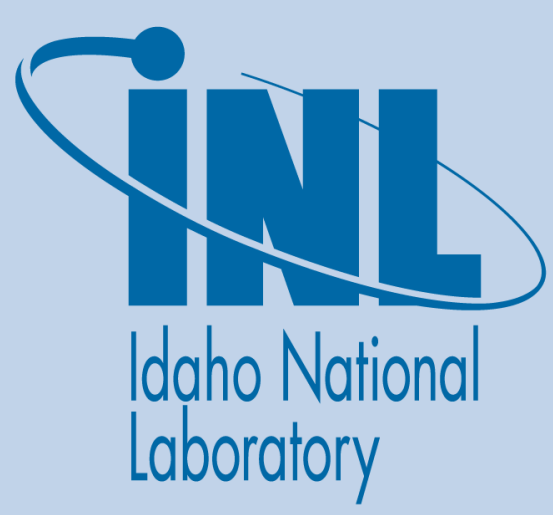

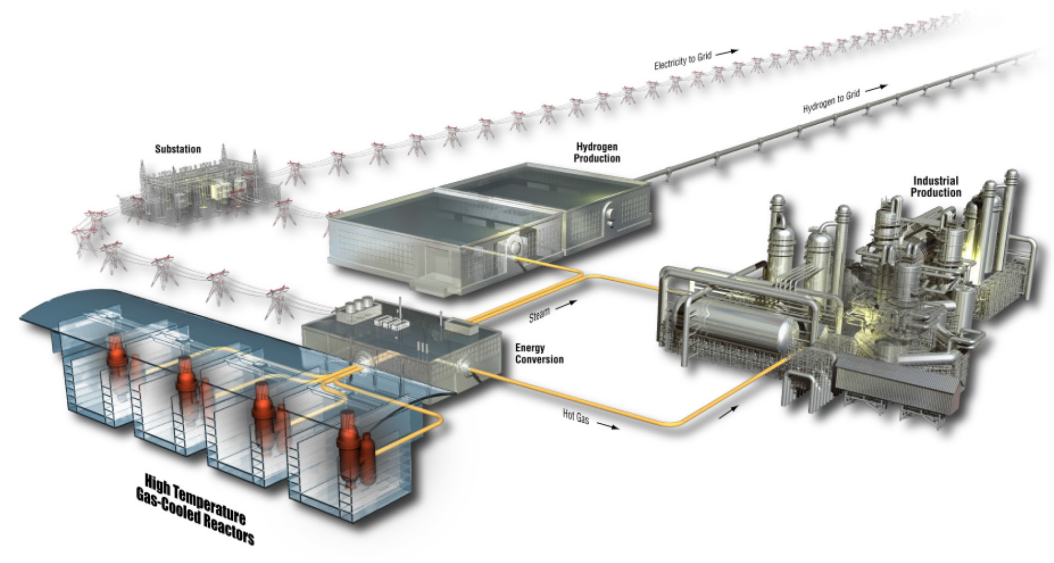




\section{DISCLAIMER}

This information was prepared as an account of work sponsored by an agency of the U.S. Government. Neither the U.S. Government nor any agency thereof, nor any of their employees, makes any warranty, expressed or implied, or assumes any legal liability or responsibility for the accuracy, completeness, or usefulness, of any information, apparatus, product, or process disclosed, or represents that its use would not infringe privately owned rights. References herein to any specific commercial product, process, or service by trade name, trade mark, manufacturer, or otherwise, does not necessarily constitute or imply its endorsement, recommendation, or favoring by the U.S. Government or any agency thereof. The views and opinions of authors expressed herein do not necessarily state or reflect those of the U.S. Government or any agency thereof. 


\title{
AGC-2 Irradiation Report
}

\author{
David Rohrbaugh \\ William Windes \\ W. David Swank
}

June 2016

\begin{abstract}
Idaho National Laboratory
INL ART TDO Program

Idaho Falls, Idaho 83415
\end{abstract}

http://www.inl.gov

Prepared for the

U.S. Department of Energy

Office of Nuclear Energy

Under DOE Idaho Operations Office

Contract DE-AC07-05ID14517 

INL ART TDO Program

AGC-2 Irradiation Report

INL/EXT-16-38431

Revision 0

June 2016

Author:
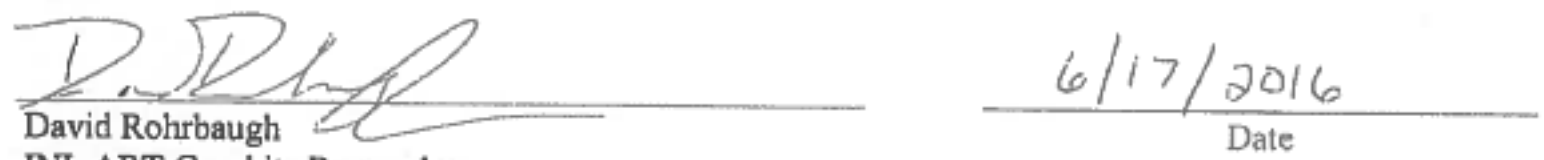

INL ART Graphite Researcher

Technical Reviewer: (Confirmation of mathematical accuracy, correctness of data, and appropriateness of assumptions.)

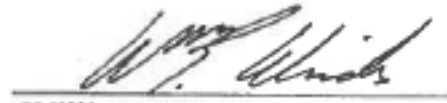

William Winds

INL ART Graphite R\&D Program Technical Lead

Approved by:

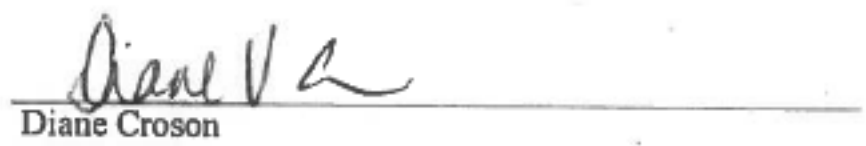

INL ART TDO Deputy Director

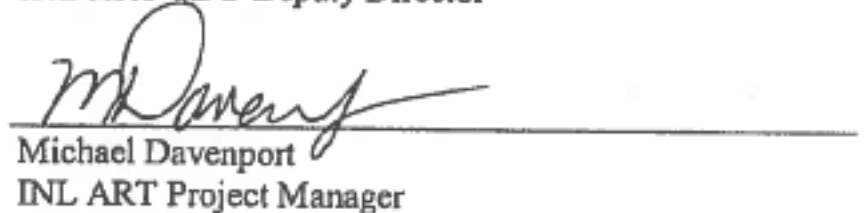

INL ART Project Manager

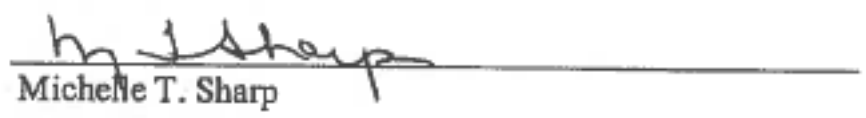

INL ART TDO Quality Assurance
$6 /, 1 / 2016$

Date
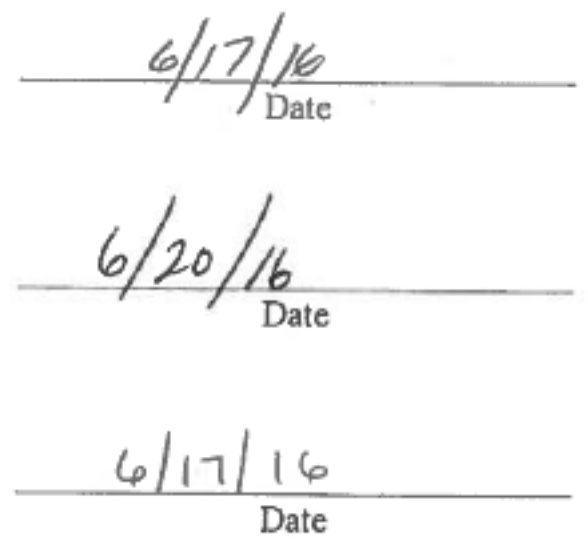



\section{SUMMARY}

The Advanced Graphite Creep (AGC)-2 capsule is the second of six planned irradiation capsules comprising the AGC experiment test series. During the AGC experiment, graphite specimens are irradiated and stressed for comparison to irradiated unstressed and unirradiated specimens to garner the quantitative data necessary for predicting the irradiation behavior and operating performance of new nuclear-grade graphite. This testing will ascertain the in-service behavior of the graphite for pebble-bed and prismatic very high-temperature reactor designs. Similar to the first AGC (i.e., AGC-1) pre-irradiation examination report, material property tests were conducted on specimens from 16 nuclear-grade graphite types. However, AGC-2 tested an increased number of specimens (i.e., 486) compared to AGC-1 (i.e., 366) [1]. The AGC-2 capsule was irradiated in the Advanced Test Reactor at Idaho National Laboratory at approximately $600^{\circ} \mathrm{C}$ and to a peak dose of 5.0 displacements per atom. All of the irradiated specimen measurements for AGC-2 were conducted at Idaho National Laboratory from April 2014 to March 2015.

This report describes the requirements and design of the second AGC (i.e., AGC-2) irradiation capsule. It summarizes how corrections were made to the specimen elevation due to thermal expansion, irradiation shrinkage, and creep. This correction allows a more accurate prediction of each specimen's temperature and dose. It also details how an average temperature, dose, and load is derived from the capsule thermocouple temperatures, reactor flux profile, and load cell data is summarized, along with a brief discussion about the uncertainty in these values. Tables containing specimen dose, temperature, and load are included in the appendices of this document for use in future creep analysis and material properties comparisons. 


\section{CONTENTS}

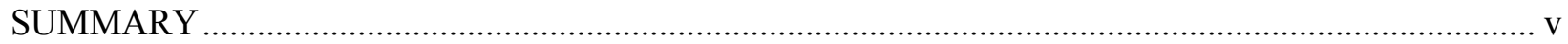

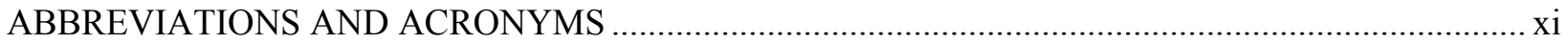

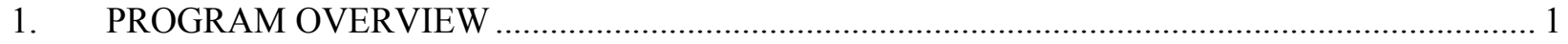

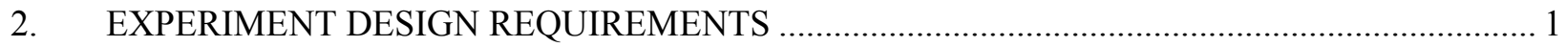

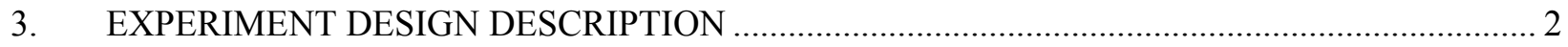

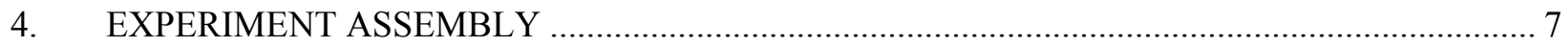

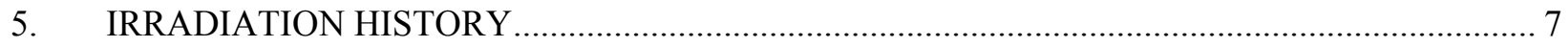

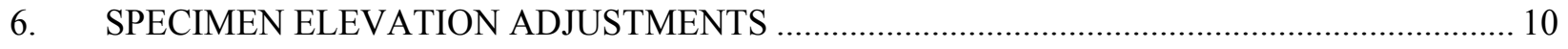

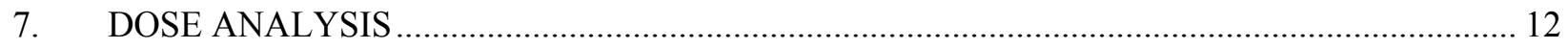

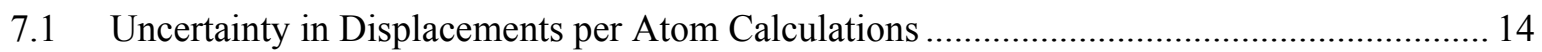

7.2 Flux Wire Spectral Measurements (AGC-2) Uncertainties ................................................ 14

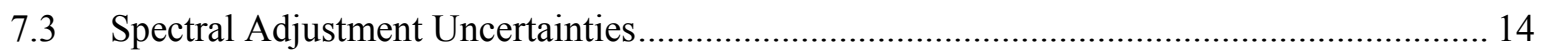

7.4 Monte Carlo N Particle/ORIGEN Model Uncertainties .................................................. 15

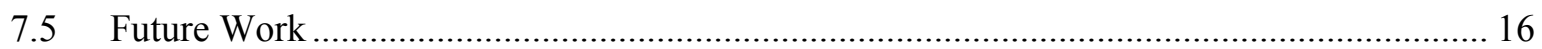

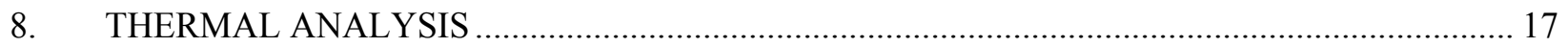

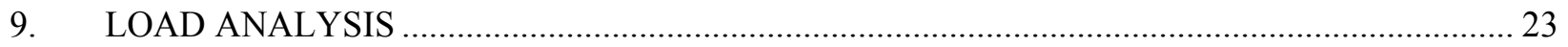

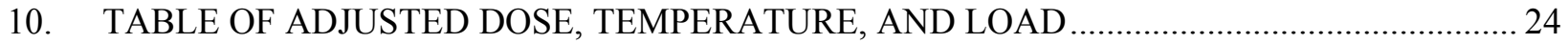

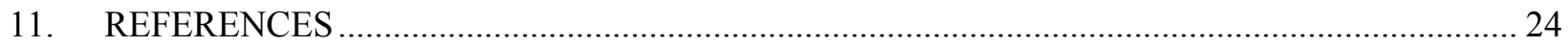

\section{FIGURES}

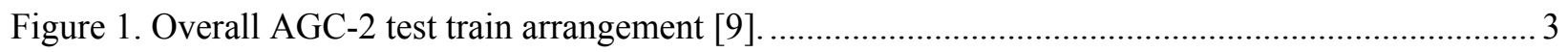

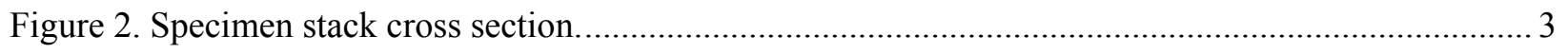

Figure 3. Compressed specimens and graphite specimen holder arrangement........................................ 4

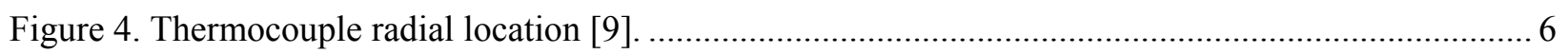

Figure 5. Mid-plane cross section of the ATR core and the location of the south flux trap. ….................... 7

Figure 6. AGC-2 capsule reactor power versus time.......................................................................... 8

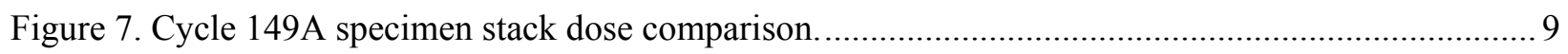

Figure 8. Total accumulated dose of AGC-2 capsule ......................................................................... 9

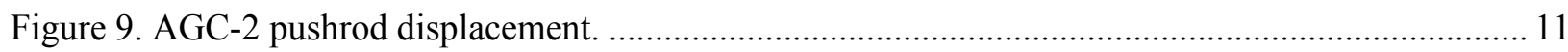


Figure 10. Specimen dpa calculation diagram.

Figure 11. Fast fluence versus position as determined from AGC-2 flux wire analysis and comparison with pre-test MCNP predictions [12].

Figure 12. Time history of thermocouple data during the AGC-2 capsule.............................................. 17

Figure 13. Measured and calculated temperature of TC-01 during all irradiation cycles.......................... 18

Figure 14. Stack 1, Cycle 149A temperature averaging and curve fit. ................................................... 19

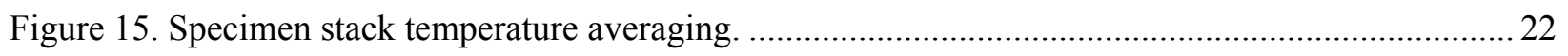

Figure 16. Compressive loads for each specimen stack over the duration of the AGC-2 capsule..............23

Figure A-1. Three-dimensional plot of the specimen dose as a function of position in the AGC capsule.

\section{TABLES}

Table 1. AGC-2 piggyback and creep specimens by grade. ............................................................. 4

Table 2. Distribution of specimens and flux monitors by stack and housing. ........................................... 5

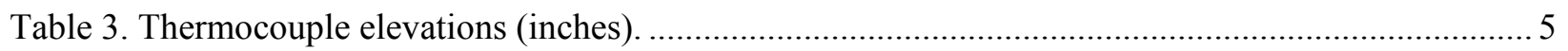

Table 4. Precision and accuracy of position calculation variables and instrumentation............................ 12

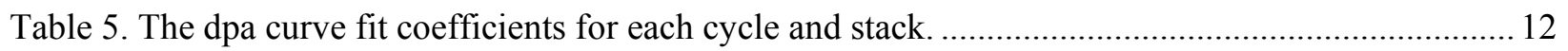

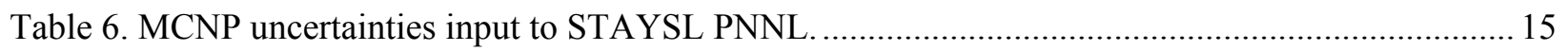

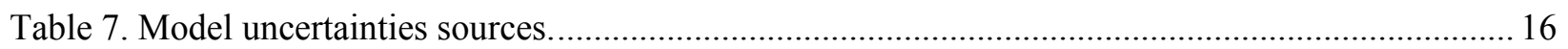

Table 8. Temperature curve fit coefficients for each cycle and stack.................................................. 20

Table 9. Curve fitting standard deviations for reactor Cycle 149A. ....................................................... 22

Table 10. Load values after application of threshold for each stack......................................................23

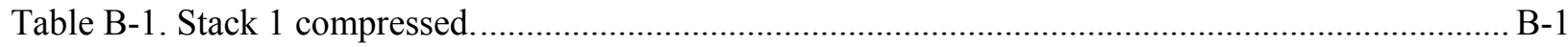

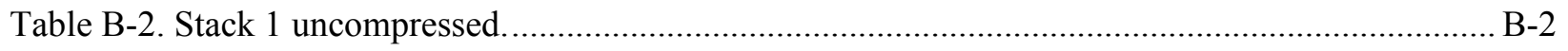

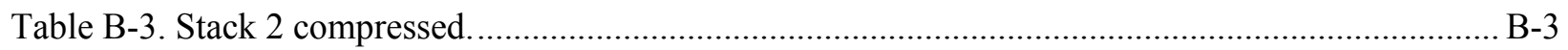

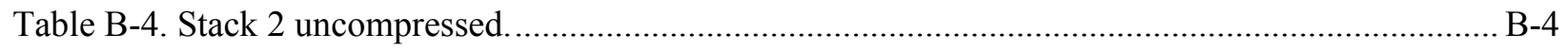

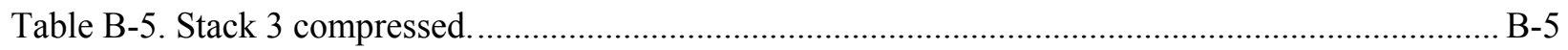

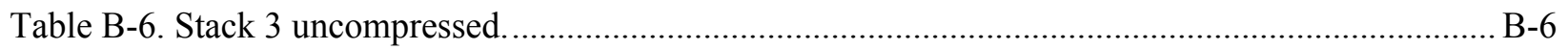

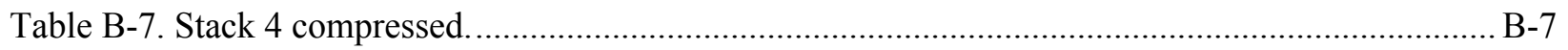

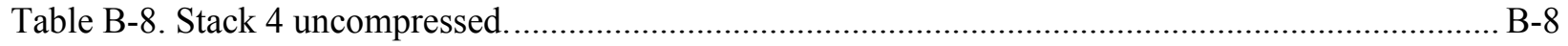

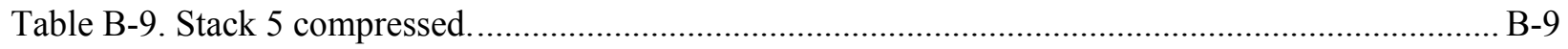

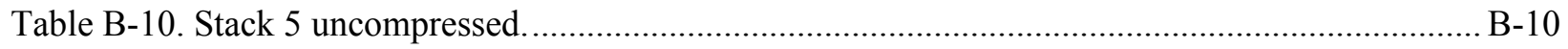

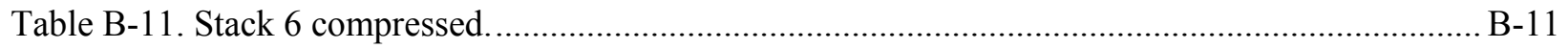

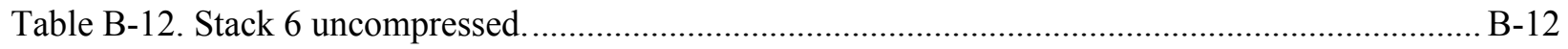

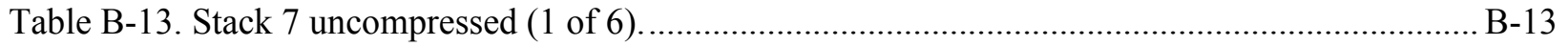




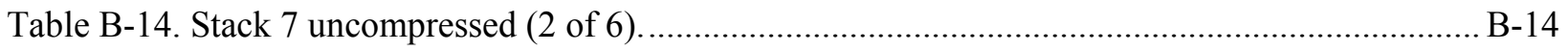

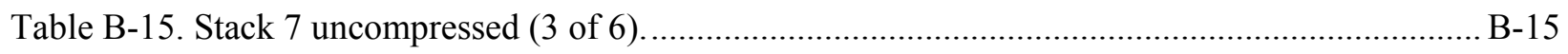

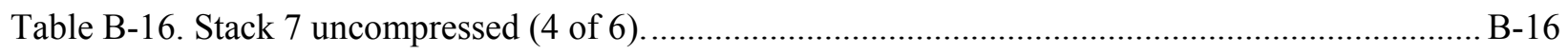

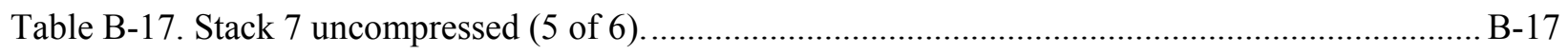

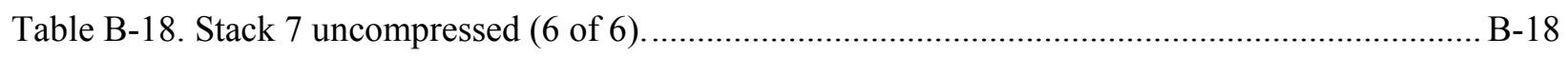




\section{ABBREVIATIONS AND ACRONYMS}

AGC advanced graphite creep

ATR Advanced Test Reactor

dpa displacements per atom

ECAR engineering calculation and analysis report

INL Idaho National Laboratory

MCNP Monte Carlo N-Particle Transport Code

HTGR High Temperature Gas-Cooled Reactors 


\section{AGC-2 Irradiation Report}

\section{PROGRAM OVERVIEW}

The High Temperature Gas-Cooled Reactors (HTGR) will be helium-cooled, very high-temperature reactor with a large graphite core. In past applications, graphite has been used effectively as a structural and moderator material in both research and commercial high-temperature gas-cooled reactor designs [2][3]. Nuclear graphite H-451 that was previously in the United States for nuclear reactor graphite components is no longer available. New nuclear graphites have been developed and are considered suitable candidates for the new NGNP reactor design. To support the design and licensing of NGNP core components within a commercial reactor, a complete properties database must be developed for these current grades of graphite. Quantitative data on in-service material performance are required for the physical, mechanical, and thermal properties of each graphite grade, with a specific emphasis on data related to the life-limiting effects of irradiation creep on key physical properties of the NGNP candidate graphite.

Based on experience with previous graphite-core components, the phenomenon of irradiation-induced creep within the graphite has been shown to be critical to the total useful lifetime of graphite components. Irradiation-induced creep occurs under the simultaneous application of high temperatures, neutron irradiation, and applied stresses within the graphite components. Significant internal stresses within the graphite components can result from a second phenomenon (i.e., irradiation-induced dimensional change). In this case, the graphite physically changes (i.e., first shrinking and then expanding with increasing neutron dose). This disparity in material-volume change can induce significant internal stresses within graphite components. Irradiation-induced creep relaxes these large internal stresses, thus reducing the risk of crack formation and component failure. Obviously, higher irradiation-creep levels tend to relieve more internal stress, thus allowing the components longer useful lifetimes within the core. Determining the irradiation-creep rates of nuclear-grade graphite is critical for determining the useful lifetime of graphite components and is a major component of the Advanced Graphite Creep (AGC) experiment.

The AGC test series is comprised of six individual capsules, each containing over 350 graphite specimens that will be irradiated in one of the large flux traps of the Advanced Test Reactor (ATR) at Idaho National Laboratory (INL) [4]. As a whole, this experimental series will examine the properties and behavior of nuclear-grade graphite over a large spectrum of temperatures, irradiation fluencies, and applied stress that are expected to induce irradiation creep strains within a very high-temperature reactor graphite component. The AGC series is currently underway; the irradiated specimen measurements for AGC-2 were conducted from April 2014 to March 2015. This characterization will be used to determine the in-service behavior of new graphite for both pebble-bed and prismatic reactor designs. Further details about research and development activities and associated rationale required to qualify nuclear-grade graphite for use within the NGNP are documented in the NGNP graphite technology research and development plan [4][5].

\section{EXPERIMENT DESIGN REQUIREMENTS}

The following requirements for graphite specimens were identified (these conditions, along with the requirements for the facility, system, and engineering design, can be found in TFR-645, "Advanced Graphite Capsule AGC-2 experiment test train") [6]:

1. All graphite specimens shall be fresh and unirradiated during initial experiment fabrication.

2. The graphite specimens and their relative position within the test train shall be as specified by the NGNP graphite material properties technical lead and DWG-600786 [7], ATR advanced graphite capsule (AGC-2) graphite specimen machining details. 
3. Specimen minimum fast neutron fluence $(E>0.1 \mathrm{MeV})>0.5 \times 1021 \mathrm{n} / \mathrm{cm}^{2}$.

4. Specimen maximum fast neutron fluence $(\mathrm{E}>0.1 \mathrm{MeV})<8.5 \times 1021 \mathrm{n} / \mathrm{cm}^{2}$.

5. Reasonable efforts shall be taken in the design of the test train materials and dimensions to limit the fast fluence difference between graphite specimens at equal axial locations above and below the core centerline to not more than $10 \%$.

6. The specimen stacks will have the capability of being placed under a maximum 3,000 psi axial compressive stress on a nominal half inch diameter specimen. The loads placed on the stacks will be evenly distributed diametrically to prevent a shift in the test internals and a change in the gas flow clearances.

7. The specimen volume-average temperatures of each large graphite specimen over the irradiation time will be $600 \pm 50^{\circ} \mathrm{C}$. Best efforts shall be made to attain $600 \pm 50^{\circ} \mathrm{C}$ volume average temperatures over the irradiation time in the small piggy-back specimens as well; however, due to their location within the test train, the temperatures in these specimens may lie outside of this tolerance band.

8. Each large graphite specimen's time average maximum temperature will not be greater than $650^{\circ} \mathrm{C}$ and each large graphite specimen's time average minimum temperature will not be less than $550^{\circ} \mathrm{C}$. Best efforts shall be made to attain $600 \pm 50^{\circ} \mathrm{C}$ time average maximum temperatures over the irradiation time in the small piggy-back specimens as well; however, due to their location within the test train, the temperatures in these specimens may lie outside of this tolerance band.

9. The AGC-2 experiment shall maximize the number of specimens at the required temperature of $600^{\circ} \mathrm{C}$ along the 4 -foot height of the core.

\section{EXPERIMENT DESIGN DESCRIPTION}

AGC-2 was designed to irradiate various grades of graphite specimens at a temperature of $600^{\circ} \mathrm{C}$ and to a peak dose of $5.0 \mathrm{dpa}$. The graphite specimens were irradiated in an instrumented leadout experiment in the south flux trap of ATR. The experiment has an overall length of 350 in. (Figure 1), with the specimen portion comprising 46 in. and being located within the 48 -in. fuel region of ATR. Although a 48-in. specimen section was desired, 46 in. was the maximum length shippable in the GE-2000 cask insert. The test train pressure boundary is constructed of 304L stainless steel. The specimen section of the shell has a nominal outside diameter of 2.5 in. with a 0.185 wall thickness. Standoff nubs are incorporated into the wall to allow concentric placement in the reactor flux trap, which ensures there is radially uniform axial coolant flow. Specimens are arranged in seven stacks (Figure 2), with each 0.5-in. diameter stack being placed within an NBG-25 graphite specimen holder.

Sixteen different grades of graphite specimens were arranged into seven stacks. Specimen Stacks 1 through 6 were split horizontally into compressed and uncompressed sections. The compressed stacks were located above the reactor mid-plane, while the uncompressed specimens were located below the reactor mid-plane. The upper sections were loaded via six pneumatic rams that are located above the specimen stacks. These rams provided nominal loads of $400 \mathrm{lb}_{\mathrm{f}}$ to Stack 1 and Stack 4, $500 \mathrm{lb}_{\mathrm{f}}$ to Stack 2 and Stack 5, and $600 \mathrm{lb}_{\mathrm{f}}$ to Stack 3 and Stack 6. The compressed specimen stacks were loaded via a graphite pushrod that transferred the load from the rams to the uppermost specimens. These pushrods were instrumented to record pushrod displacement occurring during the course of irradiation (Figure 3).

Each compressed stack (i.e., upper housing) consisted of eighteen 1-in. long creep specimens, two or four flux monitor holders, and zero or two 0.25 -in. long piggyback specimens [8]. Similar to the compressed specimen section, the uncompressed specimen stacks (i.e., lower housing) consisted of eighteen 1-in. long creep specimens, one or three flux monitor holders, and 14 or 16 piggyback specimens. The center stack consisted of 170 uncompressed 0.25 -in. long piggyback specimens only and did not incorporate flux monitor holders. Table 1 shows distribution of creep and piggyback specimens 
across each grade. Table 2 shows the type of specimens in each of the lower and upper housings, along with the number of flux monitors in each stack.

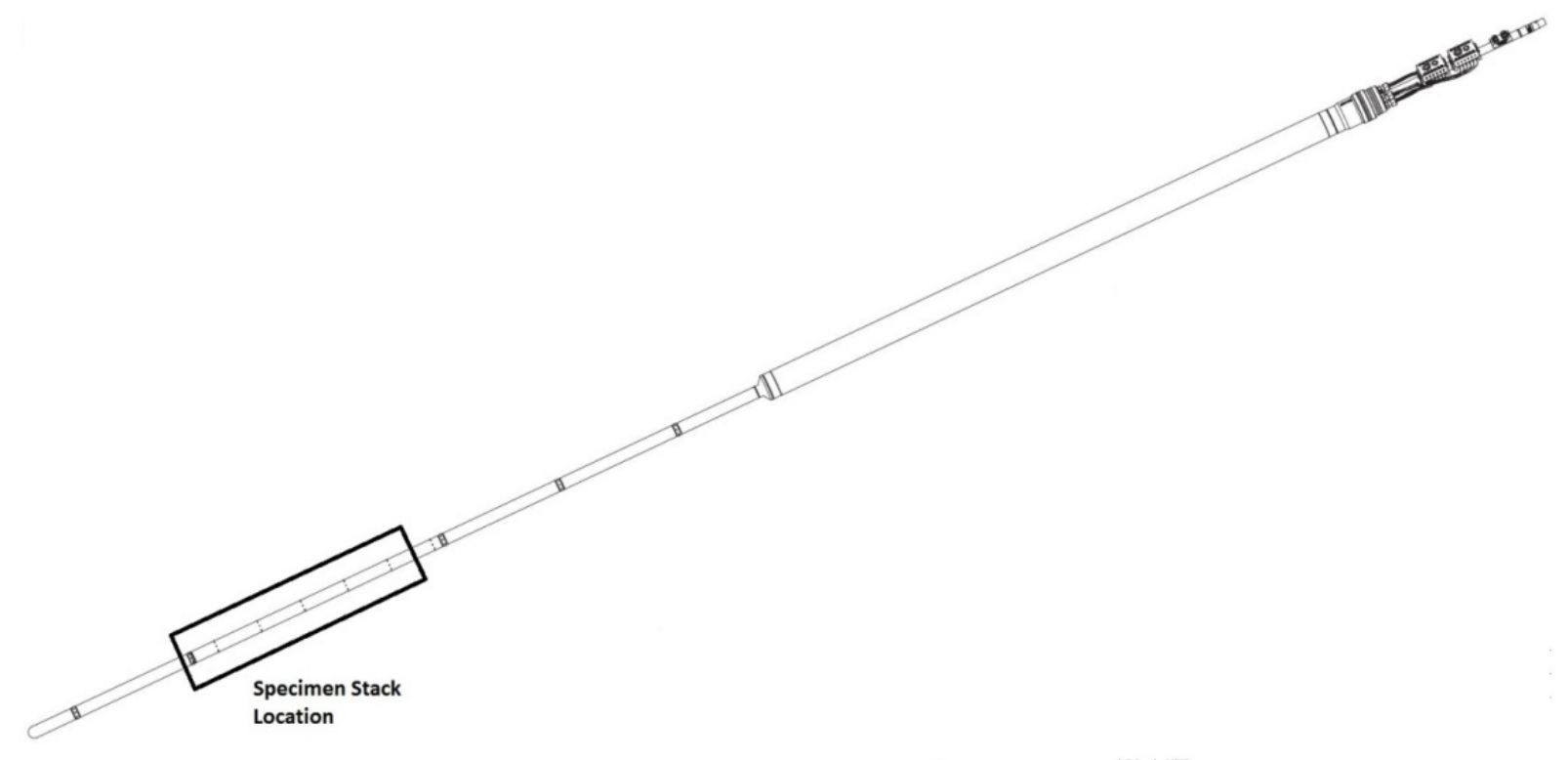

Figure 1. Overall AGC-2 test train arrangement [9].

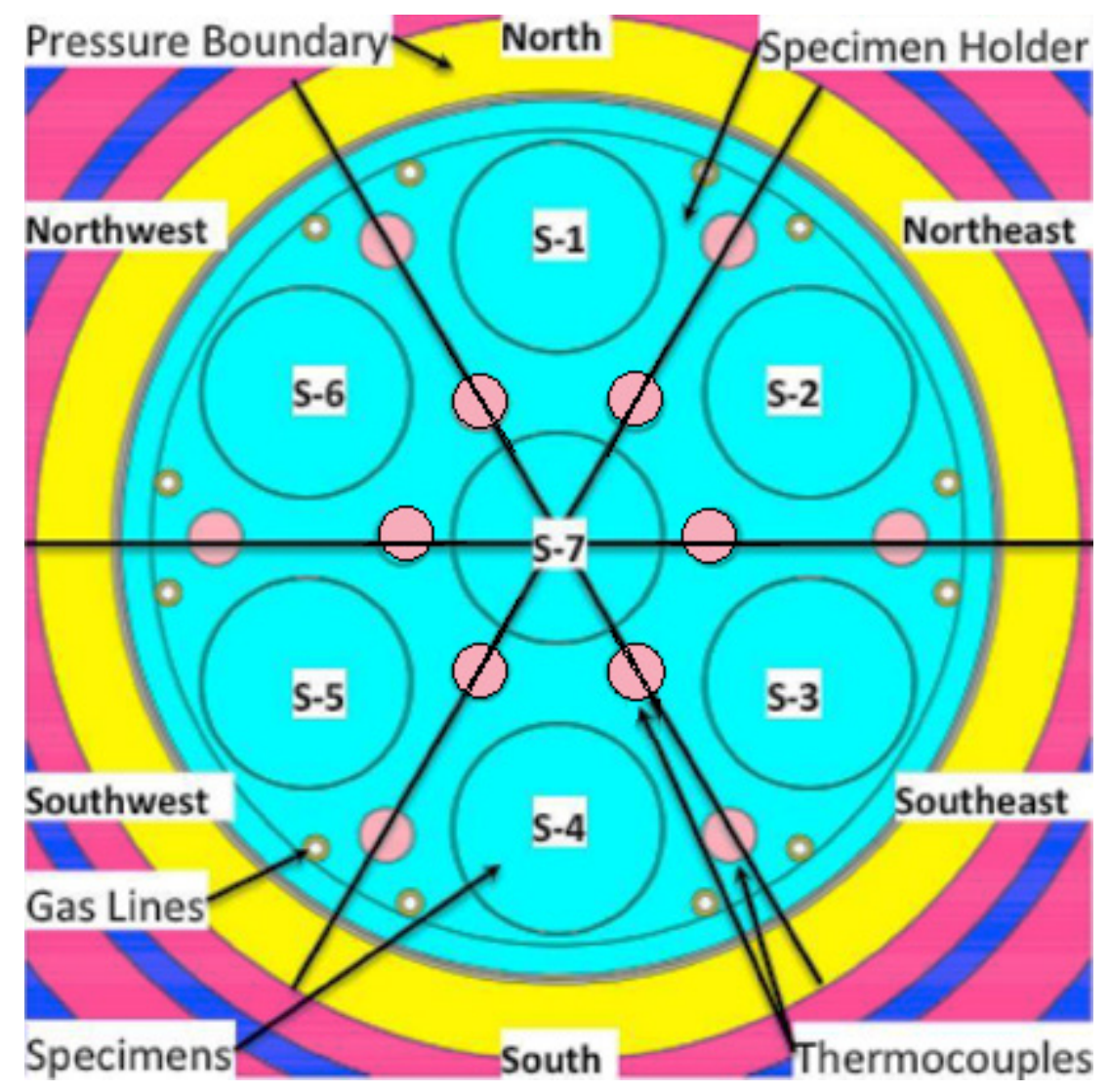

Figure 2. Specimen stack cross section. 


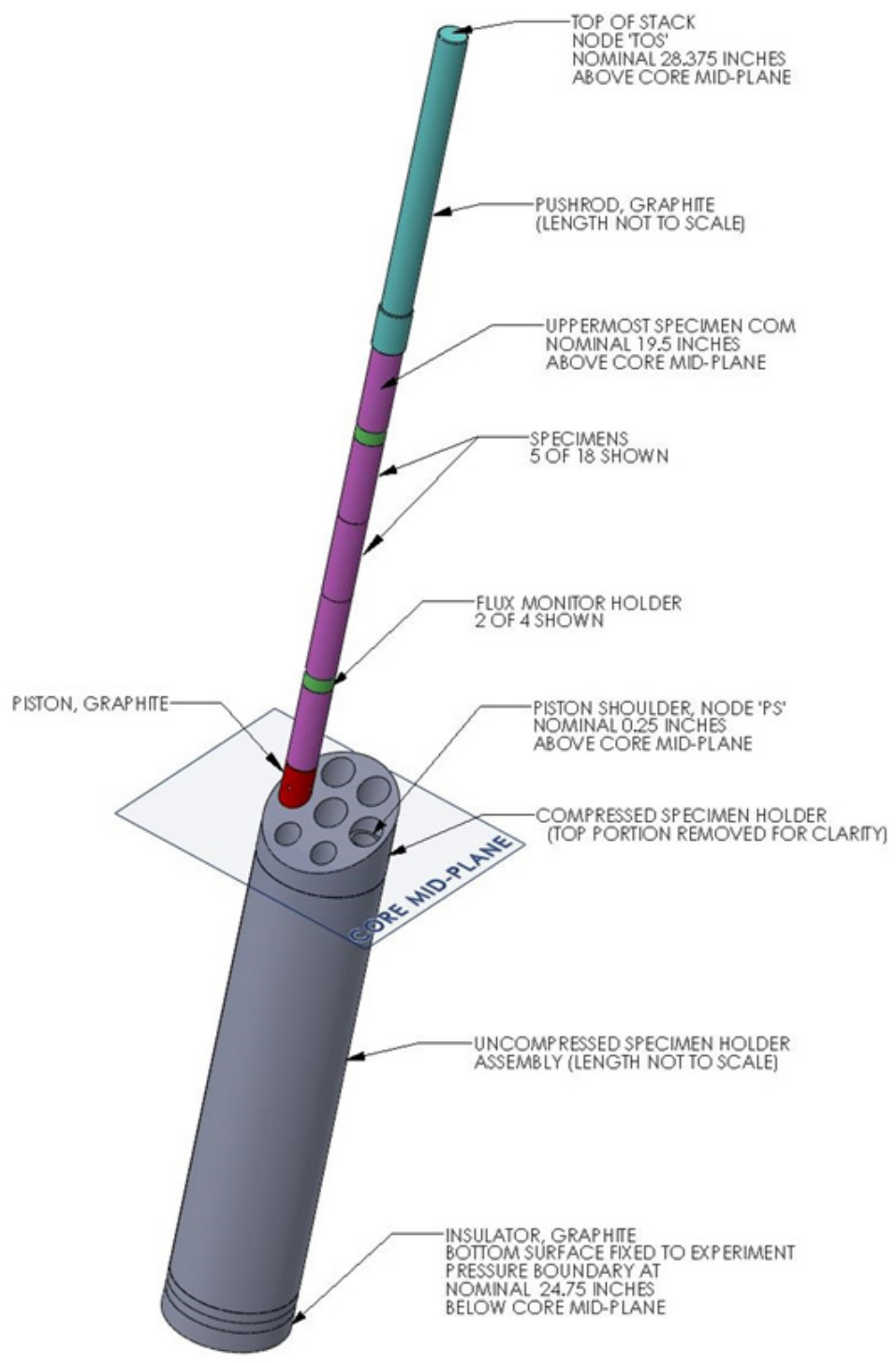

Figure 3. Compressed specimens and graphite specimen holder arrangement.

Table 1. AGC-2 piggyback and creep specimens by grade.

\begin{tabular}{lcccc}
\hline \multicolumn{1}{c}{ Grade } & Stressed Creep & Unstressed Control & Piggyback & Total \\
\hline 2114 & 0 & 0 & 27 & 27 \\
A3-3 and A3-27 & 0 & 0 & 17 & 17 \\
BAN & 0 & 0 & 17 & 17 \\
H-451 & 12 & 12 & 6 & 30 \\
HLM & 0 & 0 & 17 & 17 \\
IG-110 & 18 & 18 & 21 & 57 \\
IG-430 & 18 & 18 & 13 & 49 \\
NBG-10 & 0 & 0 & 17 & 17 \\
NBG-17 & 12 & 15 & 39 \\
NBG-18 & 12 & 24 & 13 & 61 \\
NBG-25 & 24 & 0 & 17 & 17 \\
PCEA & 0 & 24 & 15 & 63 \\
PCIB & 24 & 0 & 20 & 20 \\
\hline
\end{tabular}


Table 1. (continued).

\begin{tabular}{lcccc}
\hline \multicolumn{1}{c}{ Grade } & Stressed Creep & Unstressed Control & Piggyback & Total \\
\hline PGX & 0 & 0 & 19 & 19 \\
PPEA & 0 & 0 & 20 & 20 \\
HOPG & 0 & 0 & 16 & 16 \\
Totals & 108 & 108 & 270 & 486 \\
\hline
\end{tabular}

Table 2. Distribution of specimens and flux monitors by stack and housing.

\begin{tabular}{ccccc}
\hline Stack No. & Housing & Creep & Piggyback & Flux Mon \\
\hline 1 & lower & 18 & 14 & 3 \\
1 & upper & 18 & 0 & 4 \\
2 & lower & 18 & 16 & 1 \\
2 & upper & 18 & 2 & 2 \\
3 & lower & 18 & 16 & 1 \\
3 & upper & 18 & 2 & 2 \\
4 & lower & 18 & 14 & 3 \\
4 & upper & 18 & 0 & 4 \\
5 & lower & 18 & 16 & 1 \\
5 & upper & 18 & 2 & 2 \\
6 & lower & 18 & 16 & 2 \\
6 & upper & 18 & 2 & 0 \\
\hline
\end{tabular}

In addition to the upper load-inducing pneumatic rams for the compressed specimens, lower rams were also used during planned outages to shift the specimens stacks (i.e., compressed and uncompressed) up and down to assure the specimens do not stick in their graphite holders.

Twelve thermocouples were located within the specimen holders to record and help control specimen temperatures. Although the thermocouples did not directly measure the specimen temperature, the high conductivity of the graphite specimens and graphite holders ensured the radial temperature difference was small and could be readily determined in the thermal analysis. Table 3 lists the elevation of the thermocouples with respect to the core mid-plane, and Figure 4 shows their radial location (TC-01 through TC-12).

Table 3. Thermocouple elevations (inches).

\begin{tabular}{cc}
\hline Thermocouple Identifier & Elevation from Core Mid-Plane \\
\hline TC-01 & 18.00 \\
TC-02 & 13.00 \\
TC-03 & 13.00 \\
TC-04 & 6.00 \\
TC-05 & 6.00 \\
TC-06 & 2.00 \\
TC-07 & -6.00 \\
TC-08 & -6.00 \\
TC-09 & -11.25 \\
TC-10 & -18.00 \\
TC-11 & -18.00 \\
TC-12 & -11.25 \\
\hline
\end{tabular}




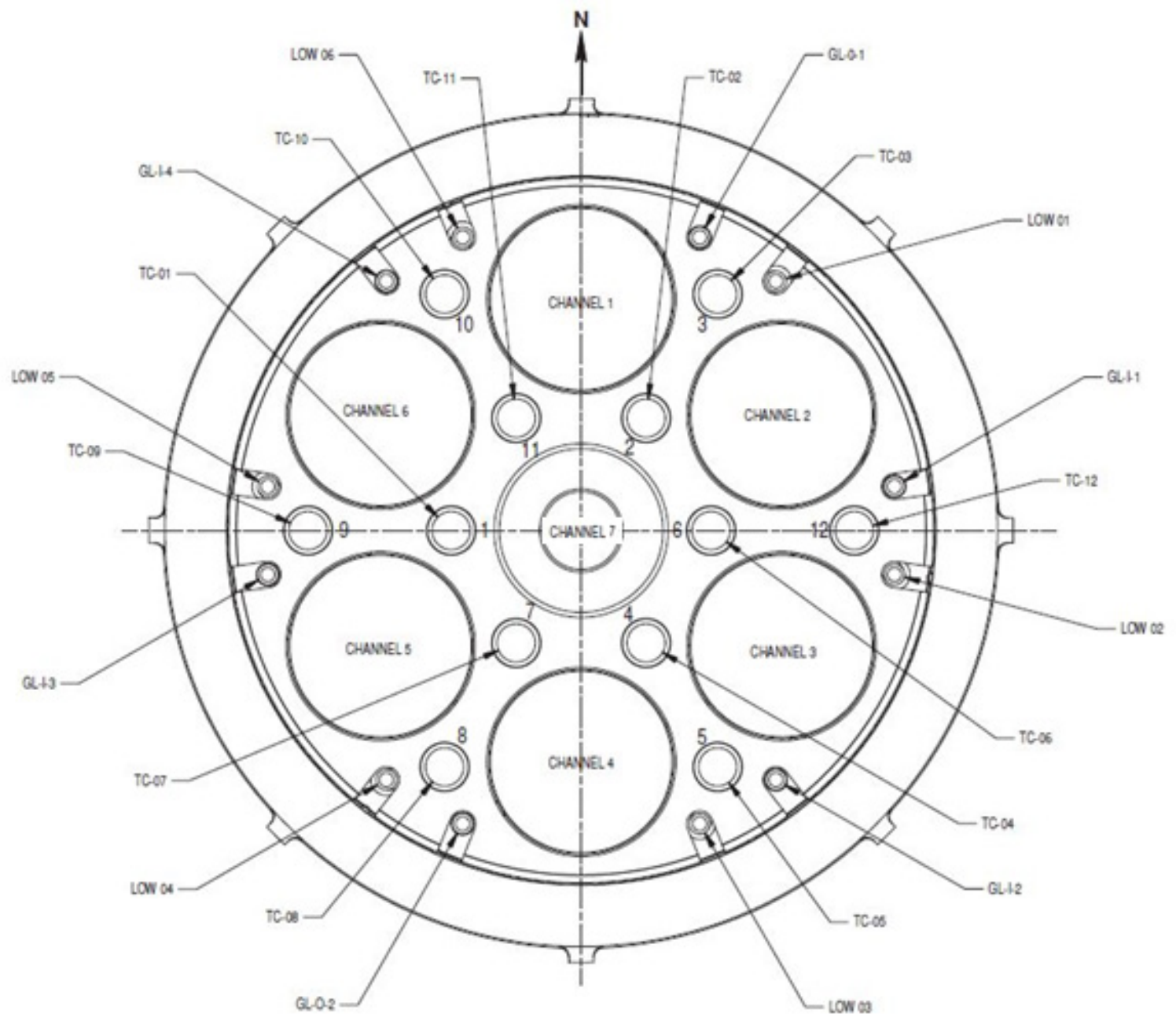

Figure 4. Thermocouple radial location [9].

The temperature within the experiment was controlled by adjusting the mixture of a helium-argon gas stream that affects the conductivity of the gas gap between the specimen holder and the capsule wall. In an effort to maintain a uniform temperature along the axis of the specimen stacks, larger gas gaps were incorporated in the upper and lower sections of the specimen holders that tend to remain cooler due to a decrease in neutron flux. To reduce the radiation heat transfer between the specimen holder and the capsule wall, a 0.002-in. thick stainless steel heat shield was installed between these two surfaces.

The overall design of the AGC-2 capsule was very similar to the AGC-1 design, with the following notable exceptions:

1. The compressed creep specimens and their uncompressed control specimens did not utilize spacers between each specimen.

2. Because spacers were not used, the number of creep specimens in each stack increased from 15 to 18 and the number of control specimens increased from 14 to 18 .

3. AGC-2 did not use silicon carbide temperature monitors, which did not require accommodating holes in the piggyback specimens. AGC-2 piggyback specimens did not have center holes machined.

4. The location of the majority of the piggyback specimens in the uncompressed portions of Stacks 1 through 6 changed from the top of the stacks to the bottom of the stacks. 


\section{EXPERIMENT ASSEMBLY}

The experiment was assembled between November 2010 and January 2011 at the Test Train Assembly Facility in the ATR Complex. A critical part of the assembly was loading the specimens into their assigned stacks and in the proper order to ensure the specimens received the desired dose. These assembly instructions and loading order are recorded in ATR Work Order No. 137268 [10]. Because the dose profile varies dramatically as a function of elevation, the loading order (and thus reactor elevational position and capsule axial orientation) was subject to double verification.

\section{IRRADIATION HISTORY}

The AGC-2 capsule was irradiated between the dates of April 12, 2011, and May 5, 2012 [11]. Figure 5 shows the location of the experiment in the south flux trap of ATR. There were five reactor cycles during this irradiation, Cycles 149A, 149B, 150B, 151A, and 151B (there was no Cycle 150A), for a total of 5,539 megawatt (MW) days or approximately 230 effective full power days. The time history of this irradiation is shown in Figure 6. As can be seen in the figure, there were planned reactor outages between each of the cycles. In addition, there was an unplanned outage in Cycle 151A and two unplanned outages in Cycle 151B.

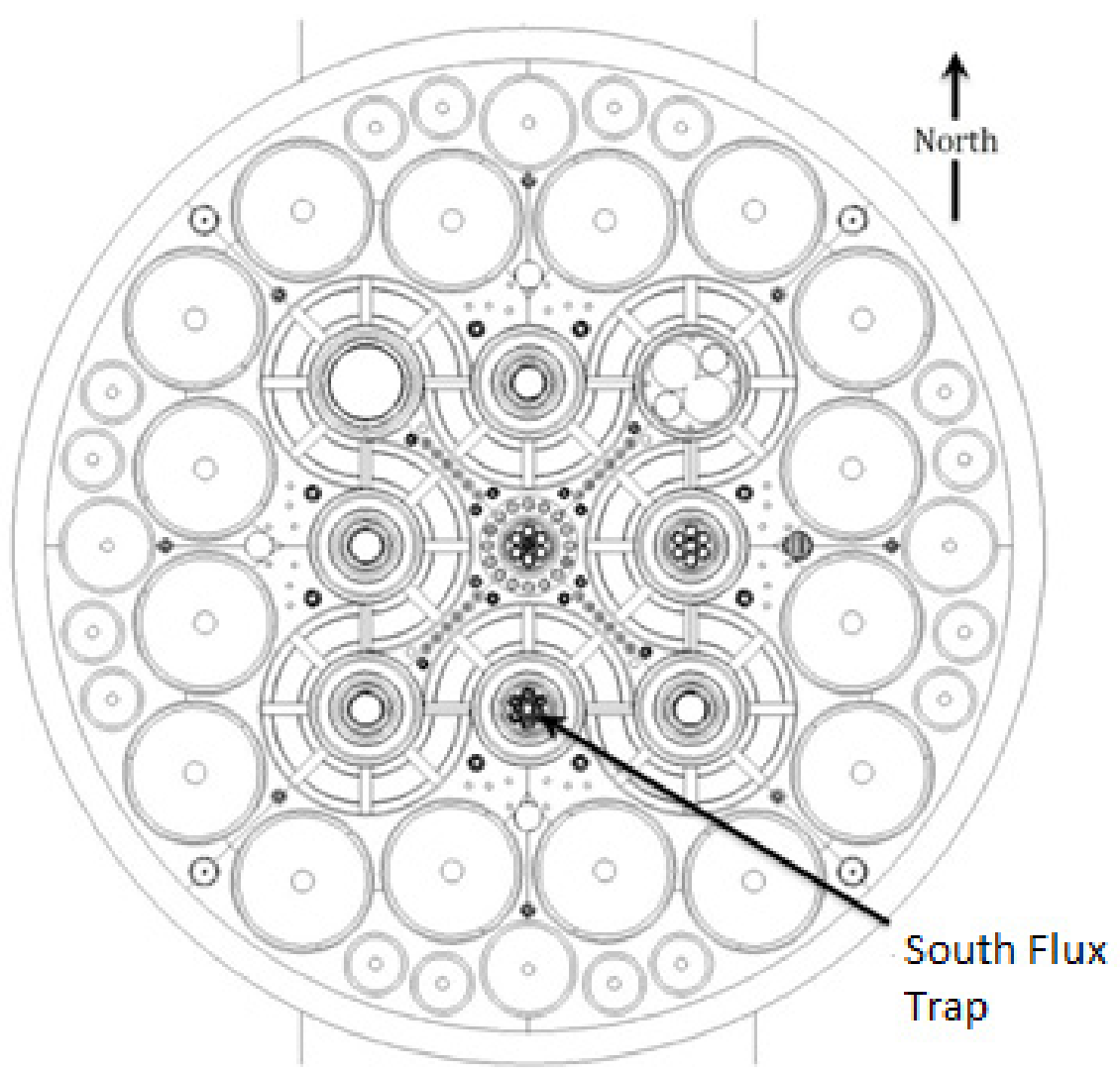

Figure 5. Mid-plane cross section of the ATR core and the location of the south flux trap. 
AGC-2 Reactor Power vs Time

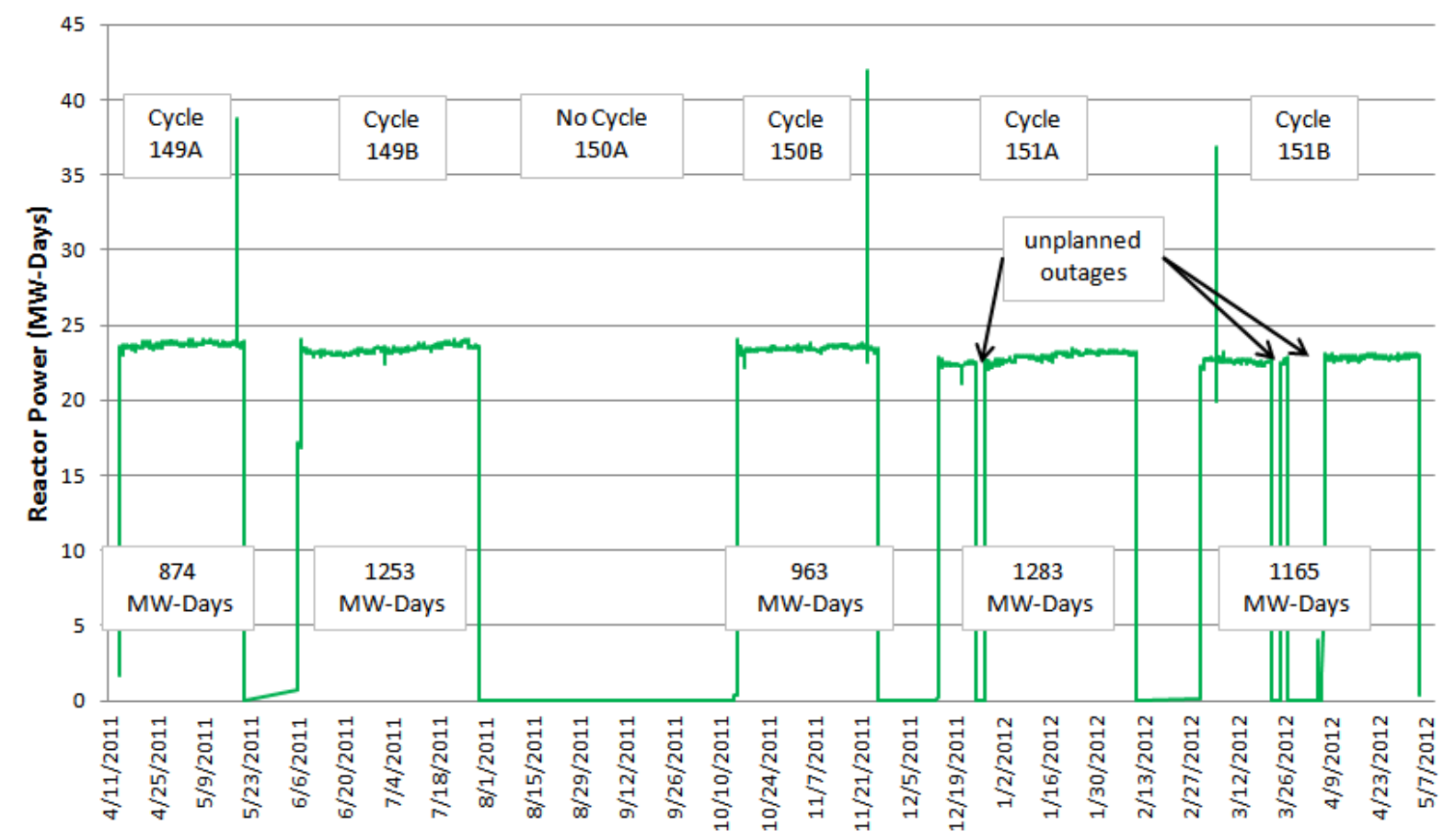

Figure 6. AGC-2 capsule reactor power versus time.

The experiment specimen stacks closest to the reactor centerline received the highest neutron dose. As can be seen in Figure 7, the Cycle 149A dose difference between the stack positions was substantial. In this particular cycle, the north position (i.e., Stack 1) received approximately $25 \%$ more dose than the south (i.e., Stack 4) position. To minimize the dose difference between the specimen stacks, the AGC-2 capsule was rotated 180 degrees between Cycles 150B and 151A (about 55\% through the total integrated irradiation). As a result, the individual stack doses at a given reactor elevation were equalized (see Figure 8). Thus, the dose difference between Stack 4 and Stack 1 was reduced to 3\%. This difference would have been even less if the integrated reactor power before and after the rotation had been equal.

After irradiation, the experiment was removed from the reactor and allowed to cool in the ATR canal. At the end of this decay period, which was necessary to achieve shippable radiation levels, the specimen section of the experiment was cut out of the test train in the ATR dry transfer cell and placed in a shielded cask insert sleeve, which, in turn, was placed in a GE-2000 shipping cask. The specimen stack section was shipped to the Hot Fuel Examination Facility in August 2013 [11]. Disassembly and specimen extraction began February 10, 2014. After the specimens were extracted, they were shipped to the Carbon Characterization Laboratory at the INL Research Center in March 2014 [11]. At the Carbon Characterization Laboratory, specimens were visually inspected, inventoried, and placed into the irradiated graphite storage vault. 


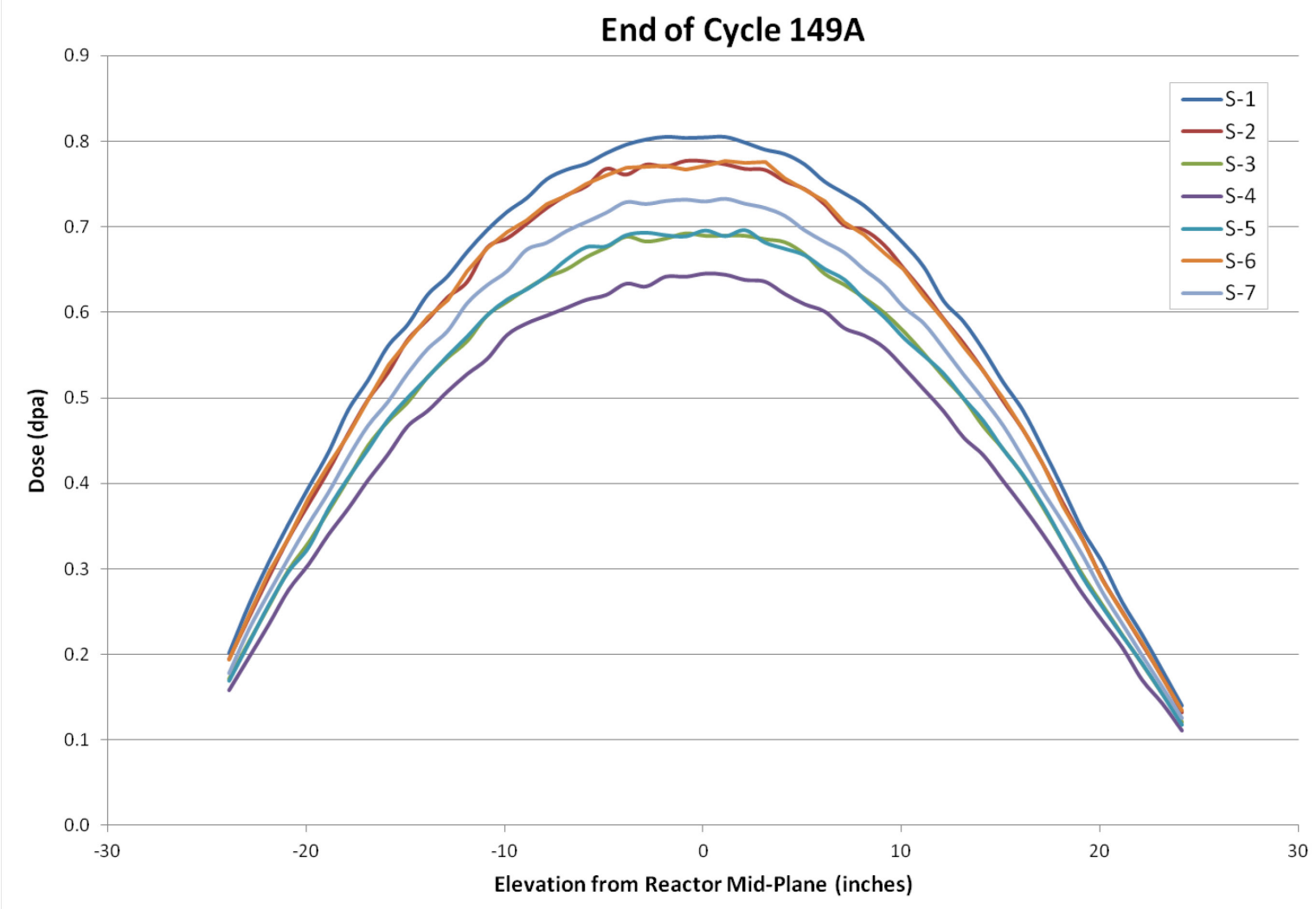

Figure 7. Cycle 149A specimen stack dose comparison.

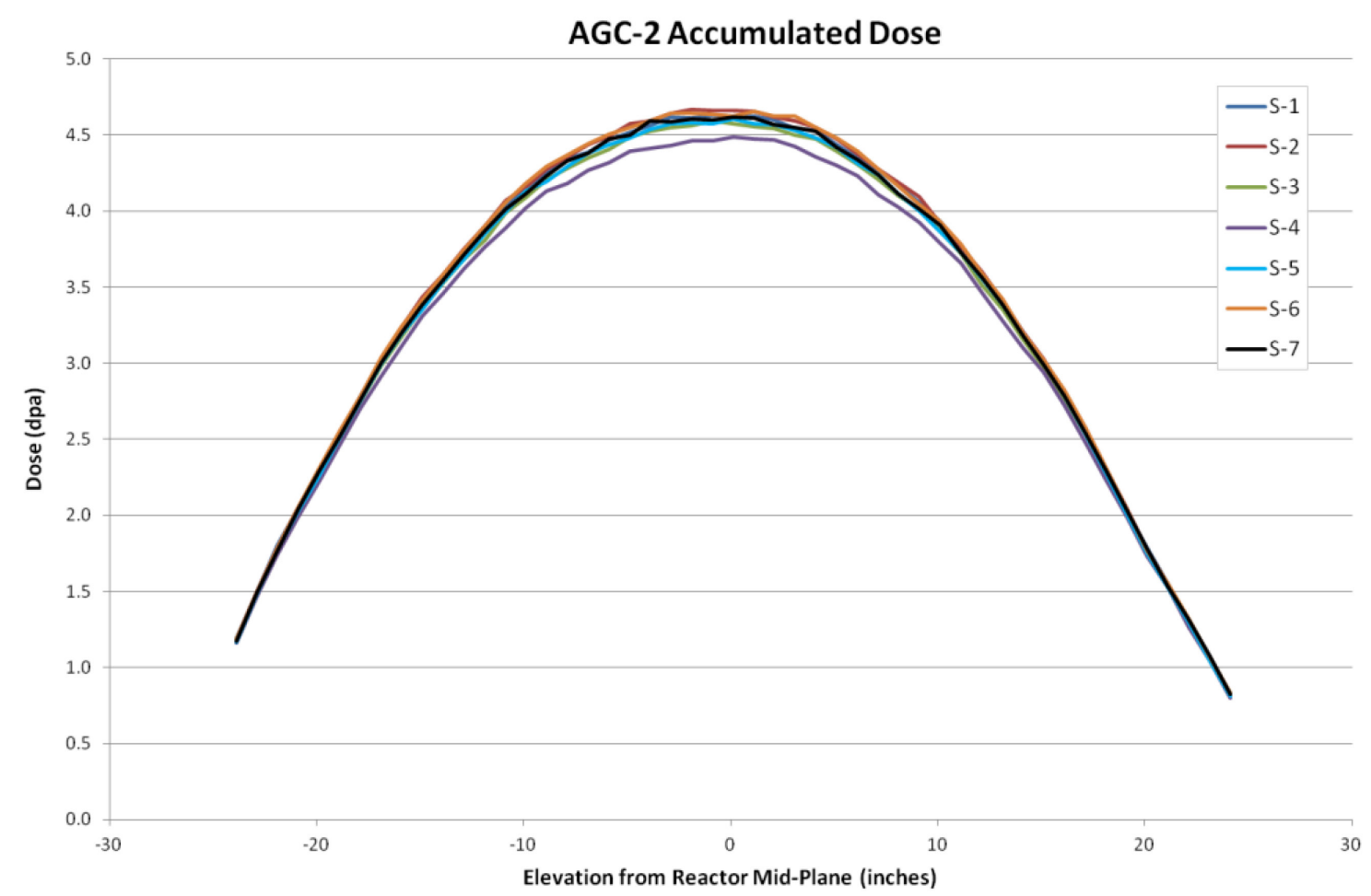

Figure 8. Total accumulated dose of AGC-2 capsule. 


\section{SPECIMEN ELEVATION ADJUSTMENTS}

The dose and temperature of each graphite specimen in the experiment were dependent on its elevation in the reactor and how close they were to the mid-plane of the core. Because of the neutroninduced graphite shrinkage and the creep of the graphite specimens and supporting specimen holders, the uppermost compressed specimens could be displaced as much as 1.4 in. during the irradiation, placing them in an $18 \%$ higher dose region. These specimen elevation adjustments were documented in ECAR-2549 [12], where the following influences on specimen position were considered:

1. As-built drawing corrections to the capsules' relative positions in the reactor.

Prior experiment insertion difficulties have shown that the distance from the reactor top-head closure plate to the core was greater than the nominal elevations shown on the ATR facility drawings. Drawing 600001 lists the measured difference between the closure plate and the gearbox support beam as 0.313 in. greater than the facility drawings. Thus, the height of the specimens in relation to the core mid-plane was 0.313 in. higher than the nominal dimensions. Also, the overall dimension of the experiment was 0.084 in. shorter than the nominal drawing dimension on Drawing 601266. As a further adjustment, the average weld shrinkage of the three capsule welds was 0.035 each, which affected the as-built position of the Lower Isolation Weld Plate (Part No. 601266-9) onto which all graphite components are stacked.

In addition to the as-built adjustments mentioned above, the specimens also were subject to a stack up error due to their thickness difference from nominal. This effect was most apparent in the center S-7 stack, which had a large number of specimens (i.e., 170 specimens). Per post-irradiation examination measurements, the average S-7 specimen was about 0.0008 in. smaller than nominal. Even though this difference was small, when multiplied by the number of specimens, the top specimen experienced an elevation reduction of $0.14 \mathrm{in}$. Although dimensional changes were less pronounced in S- 1 through S-6, specimen elevations were adjusted based on pre-irradiation length measurements.

2. Thermal expansion.

Thermal growth of the capsule wall and the graphite specimens also affected specimen position. Because the capsule and reactor are both made of similar material, their relative positions will not substantially change if they both experience the same reactor coolant temperature. However, the capsule wall temperature in the region of the core was an average of $102^{\circ} \mathrm{C}$, while the reactor coolant was an average of $52^{\circ} \mathrm{C}$. Thus, the core section of the capsule grew approximately $0.042 \mathrm{in}$., which placed the lower isolation weld plate $0.042 \mathrm{in.} \mathrm{lower} \mathrm{when} \mathrm{the} \mathrm{reactor} \mathrm{was} \mathrm{operating.} \mathrm{The} \mathrm{graphite}$ specimens and holders, all of which sit on the lower isolation weld plate, experienced an average temperature of $611^{\circ} \mathrm{C}$. As a result, the lower specimens experienced minimal thermal growth elevation change while the uppermost specimens had an upward thermal growth change of $0.20 \mathrm{in}$.

3. Shrinkage of specimens and specimen holders due to irradiation and load.

All of the specimens and components in the AGC-2 test capsule experienced some degree of radiation-induced shrinkage. During the course of irradiation, neutron damage to the graphite specimens caused the specimens to shrink and move downward. In addition to irradiation effects, the compressed specimens in S-1 through S-6 and their supporting components were also subject to load-induced creep. Therefore, as the specimen elevation changed during the course of irradiation, there was a significant change in the specimen dose and, to a lesser extent, the specimen temperature.

The compressed specimen stacks had a graphite pushrod that applied a gas cylinder load. The top of the pushrod displacement was measured by a radiation-resistant linear variable differential transducer located 94 to 107 in. above the core mid-plane; its position was recorded throughout the test in the Nuclear Data Management and Analysis System. As seen in Figure 9, the response of the linear variable differential transducers and the specimen stack creep was nearly linear. Using this fact and the influences 
listed above, an average mid-cycle elevation for each specimen was calculated and reported for each reactor cycle. This average elevation was used to make accurate predictions of the specimen temperature and dose discussed below.

AGC-2

Pushrod Displacement vs Integrated Reactor Power Cycles 149A thru 151B

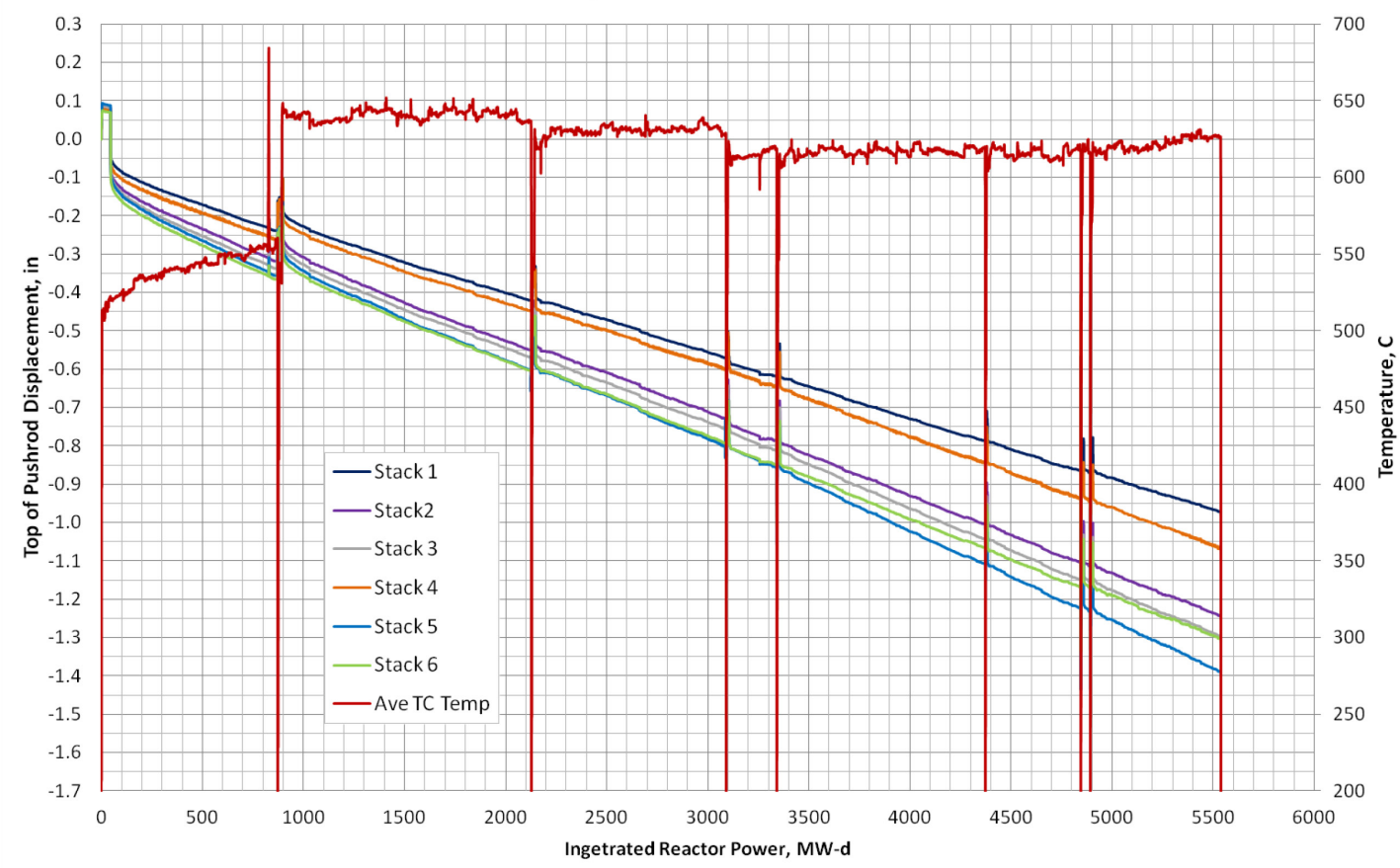

Figure 9. AGC-2 pushrod displacement.

A propagation of error analysis was performed to obtain an estimate of the uncertainty in the position values. This analysis took into consideration the uncertainties of all variables that make up the position calculation. The position is a function with the following variables:

Position $=f\left(P, L_{0}, A, E, C T E, T, L_{E n d}\right)$

where

$$
\begin{aligned}
& \mathrm{P}=\text { applied load } \\
& L_{0}=\text { specimen pre-irradiated length } \\
& A=\text { specimen cross-sectional area } \\
& E=\text { specimen pre-irradiated Young's modulus } \\
& C T E=\text { specimen pre-irradiated coefficient of thermal expansion } \\
& T=\text { specimen temperature } \\
& L_{E n d}=\text { specimen post-irradiated length. }
\end{aligned}
$$

The error in the position calculation of the specimens in the lower housing was not considered because they are not subjected to any load and, therefore, did not move as much as the specimens in the upper housing. The precision and accuracy of the dimensional (i.e., length and diameter), coefficient of thermal expansion, and Young's Modulus measurements were obtained from an inter-laboratory study between INL and Oak Ridge National Lab. Both the thermocouples' (manufactured by Idaho Laboratories 
Corporation, ILC) and the load cells' (Honeywell Corp., Model 31/AL311CV) precision and accuracy were obtained from their respective manufacturer specifications.

Table 4 shows the precision and accuracy of each of the components that go into the position's overall uncertainty calculation. A root sum square of the individual elements was computed to provide a comprehensive uncertainty for the specimen position calculations. This gave a worst case uncertainty value for the position of a specimen within the experiment (the worst case being a specimen at the top of a compressed stack at the end of the experiment). This resulted in total uncertainty of $\pm 4 \%$ of the position related to the reactor mid-plane.

Table 4. Precision and accuracy of position calculation variables and instrumentation.

\begin{tabular}{lcc}
\hline & Precision $\mathbf{( \pm \% )}$ & Accuracy $(\mathbf{\pm \%})$ \\
\hline Pre-Irradiated Length & 0.07 & 0.008 \\
Post-Irradiated Length & 0.07 & 0.008 \\
Area & - & 0.56 \\
Thermal Growth & - & 3.0 \\
Young's Modulus & 2.3 & - \\
Temperature (ILC TCs) & - & 1.0 \\
Load Cell & $0.3^{\mathrm{a}}$ & $0.05^{\mathrm{a}}$ \\
\hline
\end{tabular}

a. Of full scale.

\section{DOSE ANALYSIS}

An as-run reactor physics analysis of the dose received by the AGC-2 capsule was performed in ECAR-2291 [13]. A Monte Carlo N-Particle (MCNP) transport code was used to model and calculate the as-run displacements per atom (dpa), the fast neutron flux $(\mathrm{E}>0.1 \mathrm{MeV})$ and the heating rates (first cycle only) within the AGC-2 capsule. The heating rates were used to calculate the specimen stack temperatures (as discussed in Section 8). The dpa calculations were performed for each stack of specimens at 49 discrete elevations (in inches from reactor core mid-plane) throughout the experiment. The dpa tables reported in the ECAR are an accumulation of the dpa values through the end of each reactor cycle.

Using the accumulated dpa values from ECAR-2291 [13], dpa amounts were calculated for each individual cycle. This resulted in 35 data sets (i.e., seven stacks times five reactor cycles). A 6th order polynomial curve was applied through each of the 35 data sets. This provided a curve fit for each stack and every cycle. The total estimated accumulated dpa for a given specimen is then the sum of the evaluated dpa values for each cycle at the specimen's mid-cycle positions given in ECAR-2549 [12]. Figure A-1 in Appendix A shows a plot of the results of all curve fits by stack as a function of position in the capsule. Table 5 shows the resulting coefficients from the curve fitting described above. Figure 10 shows a diagram of how the specimen dpa was calculated from the MCNP run data.

Table 5. The dpa curve fit coefficients for each cycle and stack.

\begin{tabular}{|c|c|c|c|c|c|c|c|c|}
\hline Cycle & $\begin{array}{c}\text { Stack } \\
\text { No. }\end{array}$ & a6 & a5 & a4 & a3 & a2 & a1 & a0 \\
\hline $149 \mathrm{~A}$ & 1 & $7.2837 \mathrm{E}-10$ & $1.2811 \mathrm{E}-08$ & $-5.2488 \mathrm{E}-07$ & $-7.4389 \mathrm{E}-06$ & $-1.0393 \mathrm{E}-03$ & $-1.0566 \mathrm{E}-03$ & $8.0576 \mathrm{E}-01$ \\
\hline $149 \mathrm{~A}$ & 2 & $6.9695 \mathrm{E}-10$ & $1.0113 \mathrm{E}-08$ & $-4.6034 \mathrm{E}-07$ & $-5.6438 \mathrm{E}-06$ & $-1.0296 \mathrm{E}-03$ & $-1.1854 \mathrm{E}-03$ & $7.7612 \mathrm{E}-01$ \\
\hline $149 \mathrm{~A}$ & 3 & $4.5906 \mathrm{E}-10$ & $1.1801 \mathrm{E}-08$ & $-2.2051 \mathrm{E}-07$ & $-6.8585 \mathrm{E}-06$ & $-9.7610 \mathrm{E}-04$ & $-7.9748 \mathrm{E}-04$ & $6.9296 \mathrm{E}-01$ \\
\hline $149 \mathrm{~A}$ & 4 & $4.8008 \mathrm{E}-10$ & $9.7006 \mathrm{E}-09$ & $-2.2962 \mathrm{E}-07$ & $-5.1520 \mathrm{E}-06$ & $-9.0851 \mathrm{E}-04$ & $-1.0133 \mathrm{E}-03$ & $6.4224 \mathrm{E}-01$ \\
\hline $149 \mathrm{~A}$ & 5 & $4.6682 \mathrm{E}-10$ & $8.5818 \mathrm{E}-09$ & $-2.2769 \mathrm{E}-07$ & $-4.2802 \mathrm{E}-06$ & $-9.8218 \mathrm{E}-04$ & $-1.2638 \mathrm{E}-03$ & $6.9572 \mathrm{E}-01$ \\
\hline $149 \mathrm{~A}$ & 6 & $6.2628 \mathrm{E}-10$ & $1.1245 \mathrm{E}-08$ & $-4.0055 \mathrm{E}-07$ & $-6.0865 \mathrm{E}-06$ & $-1.0402 \mathrm{E}-03$ & $-1.2967 \mathrm{E}-03$ & $7.7712 \mathrm{E}-01$ \\
\hline
\end{tabular}


Table 5. (continued).

\begin{tabular}{|c|c|c|c|c|c|c|c|c|}
\hline Cycle & $\begin{array}{c}\text { Stack } \\
\text { No. }\end{array}$ & a6 & a5 & a4 & a3 & a2 & a1 & $\mathrm{a} 0$ \\
\hline $149 \mathrm{~A}$ & 7 & 5.5614E-10 & $8.1201 \mathrm{E}-09$ & $-3.1877 \mathrm{E}-07$ & $-3.8087 E-06$ & $-1.0084 \mathrm{E}-03$ & $-1.4563 \mathrm{E}-03$ & 7.3351E-01 \\
\hline $149 B$ & 1 & $1.3551 \mathrm{E}-09$ & $1.5014 \mathrm{E}-08$ & $-1.0338 \mathrm{E}-06$ & $-8.5283 \mathrm{E}-06$ & $-1.4196 \mathrm{E}-03$ & $-1.7074 \mathrm{E}-03$ & $1.1509 \mathrm{E}+00$ \\
\hline $149 B$ & 2 & 7.5796E-10 & $1.3628 \mathrm{E}-08$ & $-4.2456 \mathrm{E}-07$ & $-7.3019 E-06$ & $-1.5298 \mathrm{E}-03$ & $-1.8316 \mathrm{E}-03$ & $1.1138 \mathrm{E}+00$ \\
\hline $149 B$ & 3 & 7.3973E-10 & 1.3389E-08 & $-3.7667 \mathrm{E}-07$ & $-6.9812 \mathrm{E}-06$ & $-1.3848 \mathrm{E}-03$ & $-1.6202 \mathrm{E}-03$ & $9.9177 \mathrm{E}-01$ \\
\hline $149 B$ & 4 & $7.7042 \mathrm{E}-10$ & $1.1088 \mathrm{E}-08$ & $-3.9734 \mathrm{E}-07$ & $-5.8395 \mathrm{E}-06$ & $-1.2812 \mathrm{E}-03$ & $-1.4394 \mathrm{E}-03$ & $9.1605 \mathrm{E}-01$ \\
\hline $149 B$ & 5 & $7.7425 \mathrm{E}-10$ & 1.2700E-08 & $-3.9695 \mathrm{E}-07$ & $-7.2789 \mathrm{E}-06$ & $-1.3892 \mathrm{E}-03$ & $-1.3214 \mathrm{E}-03$ & 9.9207E-01 \\
\hline 149B & 6 & $1.0615 \mathrm{E}-09$ & $1.4868 \mathrm{E}-08$ & $-7.2593 E-07$ & $-8.2242 \mathrm{E}-06$ & $-1.4393 \mathrm{E}-03$ & $-1.6101 \mathrm{E}-03$ & $1.1043 \mathrm{E}+00$ \\
\hline $149 B$ & 7 & $7.0035 \mathrm{E}-10$ & 1.4527E-08 & $-3.6619 \mathrm{E}-07$ & $-8.2046 \mathrm{E}-06$ & $-1.4577 \mathrm{E}-03$ & $-1.3803 \mathrm{E}-03$ & $1.0492 \mathrm{E}+00$ \\
\hline $150 B$ & 1 & $1.0146 \mathrm{E}-09$ & $1.2741 \mathrm{E}-08$ & $-9.2105 E-07$ & $-7.3689 \mathrm{E}-06$ & $-1.0140 \mathrm{E}-03$ & $-1.2763 \mathrm{E}-03$ & $8.9768 \mathrm{E}-01$ \\
\hline $150 B$ & 2 & $9.9886 \mathrm{E}-10$ & $1.2354 \mathrm{E}-08$ & $-8.3522 \mathrm{E}-07$ & $-6.9698 \mathrm{E}-06$ & $-1.0117 \mathrm{E}-03$ & $-1.2707 \mathrm{E}-03$ & 8.6237E-01 \\
\hline $150 B$ & 3 & $7.2928 \mathrm{E}-10$ & $9.5350 \mathrm{E}-09$ & $-5.3704 \mathrm{E}-07$ & $-5.2863 \mathrm{E}-06$ & $-9.7297 \mathrm{E}-04$ & $-1.1664 \mathrm{E}-03$ & 7.6927E-01 \\
\hline $150 B$ & 4 & 6.0749E-10 & $1.0705 \mathrm{E}-08$ & $-4.3067 \mathrm{E}-07$ & $-5.9250 \mathrm{E}-06$ & $-9.2283 E-04$ & $-1.0011 \mathrm{E}-03$ & 7.1241E-01 \\
\hline $150 B$ & 5 & $8.8570 \mathrm{E}-10$ & $1.0368 \mathrm{E}-08$ & $-6.8492 \mathrm{E}-07$ & $-5.7426 \mathrm{E}-06$ & $-9.4176 \mathrm{E}-04$ & $-1.2013 \mathrm{E}-03$ & 7.6944E-01 \\
\hline $150 B$ & 6 & $8.9888 \mathrm{E}-10$ & 1.0963E-08 & $-7.2304 \mathrm{E}-07$ & $-5.8688 \mathrm{E}-06$ & $-1.0460 \mathrm{E}-03$ & $-1.4960 \mathrm{E}-03$ & $8.6382 \mathrm{E}-01$ \\
\hline $150 B$ & 7 & $8.5398 \mathrm{E}-10$ & 9.8911E-09 & $-6.5854 \mathrm{E}-07$ & $-5.4793 \mathrm{E}-06$ & $-1.0072 E-03$ & $-1.2881 \mathrm{E}-03$ & $8.1618 \mathrm{E}-01$ \\
\hline $151 \mathrm{~A}$ & 1 & $1.0448 \mathrm{E}-09$ & $1.3578 \mathrm{E}-08$ & $-8.1914 \mathrm{E}-07$ & $-7.7176 \mathrm{E}-06$ & $-1.1337 \mathrm{E}-03$ & $-1.3092 \mathrm{E}-03$ & $9.3234 \mathrm{E}-01$ \\
\hline $151 \mathrm{~A}$ & 2 & $1.1293 \mathrm{E}-09$ & $1.4996 \mathrm{E}-08$ & $-9.2033 E-07$ & $-8.3851 \mathrm{E}-06$ & $-1.2047 \mathrm{E}-03$ & $-1.4243 \mathrm{E}-03$ & $1.0070 \mathrm{E}+00$ \\
\hline $151 \mathrm{~A}$ & 3 & $1.1472 \mathrm{E}-09$ & 1.5817E-08 & $-1.0241 \mathrm{E}-06$ & $-9.0650 \mathrm{E}-06$ & $-1.2976 \mathrm{E}-03$ & $-1.5990 \mathrm{E}-03$ & $1.1228 \mathrm{E}+00$ \\
\hline $151 \mathrm{~A}$ & 4 & 1.2799E-09 & 1.8983E-08 & $-1.2260 \mathrm{E}-06$ & $-1.1775 E-05$ & $-1.2723 \mathrm{E}-03$ & $-1.2029 \mathrm{E}-03$ & $1.1645 \mathrm{E}+00$ \\
\hline $151 \mathrm{~A}$ & 5 & $1.3416 \mathrm{E}-09$ & 1.7793E-08 & $-1.2329 E-06$ & $-1.0893 \mathrm{E}-05$ & $-1.2407 \mathrm{E}-03$ & $-1.2413 \mathrm{E}-03$ & $1.1204 \mathrm{E}+00$ \\
\hline $151 \mathrm{~A}$ & 6 & $1.0422 \mathrm{E}-09$ & $1.2318 \mathrm{E}-08$ & $-8.6321 E-07$ & $-6.5223 \mathrm{E}-06$ & $-1.2058 \mathrm{E}-03$ & $-1.6834 \mathrm{E}-03$ & $1.0044 \mathrm{E}+00$ \\
\hline $151 \mathrm{~A}$ & 7 & $1.1045 \mathrm{E}-09$ & $1.6001 \mathrm{E}-08$ & $-9.6247 \mathrm{E}-07$ & $-9.0137 \mathrm{E}-06$ & $-1.2390 \mathrm{E}-03$ & $-1.5121 \mathrm{E}-03$ & $1.0619 \mathrm{E}+00$ \\
\hline $151 \mathrm{~B}$ & 1 & 7.7567E-10 & $1.3200 \mathrm{E}-08$ & $-5.3316 \mathrm{E}-07$ & $-7.5967 \mathrm{E}-06$ & $-1.0956 \mathrm{E}-03$ & $-1.0754 \mathrm{E}-03$ & $8.4439 \mathrm{E}-01$ \\
\hline 151B & 2 & $1.0998 \mathrm{E}-09$ & $1.0352 \mathrm{E}-08$ & $-8.1264 \mathrm{E}-07$ & $-5.1945 E-06$ & $-1.1243 \mathrm{E}-03$ & $-1.6888 \mathrm{E}-03$ & $9.0640 \mathrm{E}-01$ \\
\hline 151B & 3 & $1.2964 \mathrm{E}-09$ & 1.2936E-08 & $-1.0725 \mathrm{E}-06$ & $-7.3239 \mathrm{E}-06$ & $-1.1592 \mathrm{E}-03$ & $-1.5090 \mathrm{E}-03$ & $1.0038 \mathrm{E}+00$ \\
\hline 151B & 4 & $1.2852 \mathrm{E}-09$ & $9.2715 \mathrm{E}-09$ & $-1.1748 \mathrm{E}-06$ & $-5.1742 E-06$ & $-1.1506 \mathrm{E}-03$ & $-1.8932 \mathrm{E}-03$ & $1.0457 \mathrm{E}+00$ \\
\hline 151B & 5 & $9.9049 \mathrm{E}-10$ & $1.3004 \mathrm{E}-08$ & $-8.5178 \mathrm{E}-07$ & $-7.4535 \mathrm{E}-06$ & $-1.2167 \mathrm{E}-03$ & $-1.5341 \mathrm{E}-03$ & $1.0189 E+00$ \\
\hline 151B & 6 & $9.9035 \mathrm{E}-10$ & $1.4245 \mathrm{E}-08$ & $-7.7834 \mathrm{E}-07$ & $-7.8859 \mathrm{E}-06$ & $-1.1184 \mathrm{E}-03$ & $-1.3018 \mathrm{E}-03$ & $9.1206 \mathrm{E}-01$ \\
\hline 151B & 7 & 5.7700E-10 & $9.3612 \mathrm{E}-09$ & $-4.4200 E-07$ & $-4.0913 \mathrm{E}-06$ & $-1.2384 \mathrm{E}-03$ & $-2.0826 \mathrm{E}-03$ & $9.6035 \mathrm{E}-01$ \\
\hline
\end{tabular}




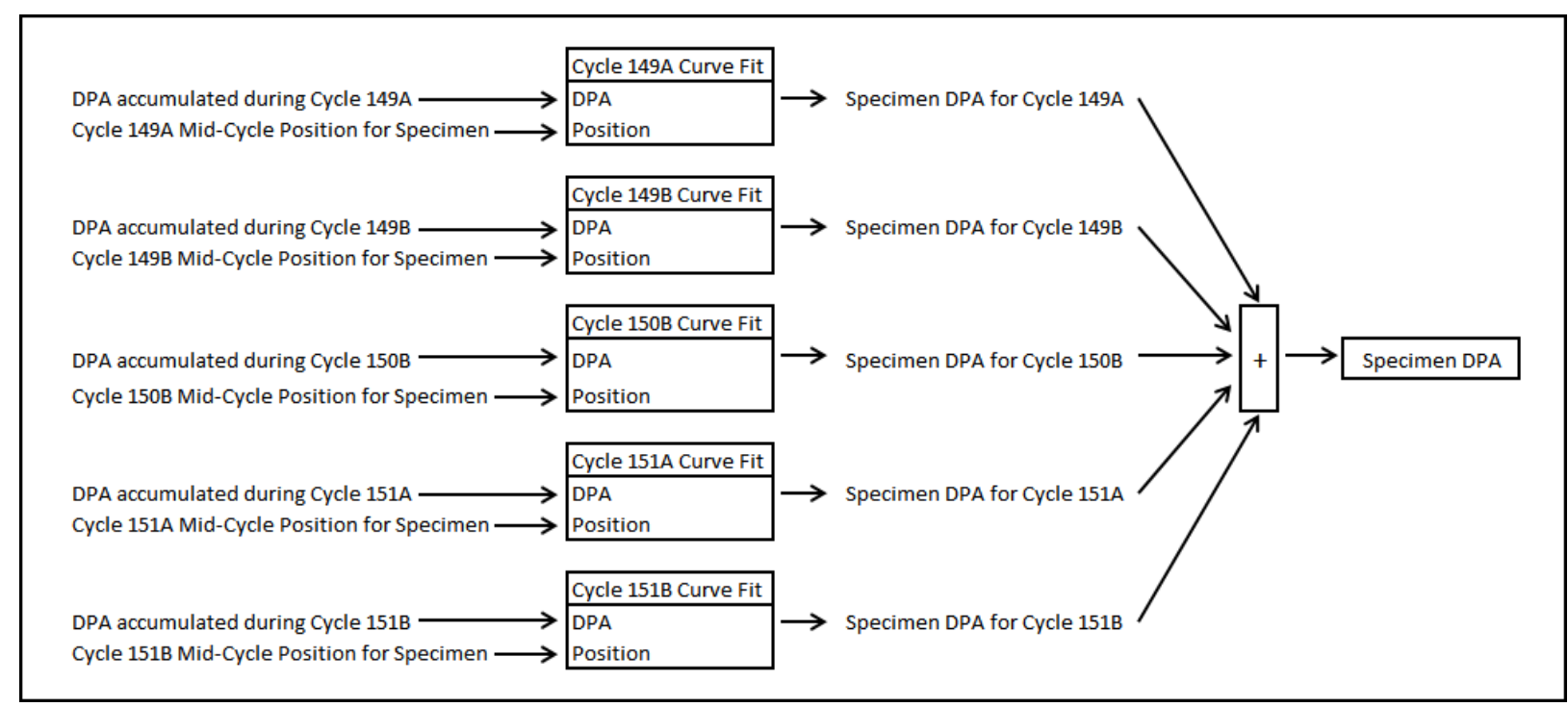

Figure 10. Specimen dpa calculation diagram.

\subsection{Uncertainty in Displacements per Atom Calculations}

Uncertainties exist at every step of the calculation and measurement process used in determining the dpa in the AGC experiment. Some uncertainties contribute very little to output uncertainties (e.g., experiment geometry dimensions), while others have large impacts (e.g., power measurement). The uncertainty of the determined fast fluence within the graphite samples was dominated by model uncertainty. The data assimilation process, where experimental flux wire results were combined with the results of the high fidelity simulations, relied heavily on the model results because only two data points were determined experimentally, whereas the model provided 100s of data points. The sources and determined values of uncertainties for the determined AGC dpa are described in the following subsections.

\subsection{Flux Wire Spectral Measurements (AGC-2) Uncertainties}

The radiation counting process contributed little uncertainty to the total dpa calculations; however, long decay times between irradiation and measurement made it difficult to collect all relevant data. The uncertainties in the ${ }^{54} \mathrm{Mn}$ and ${ }^{94} \mathrm{Nb}$ measurements were $3 \%$ in every case. Only one of the two ${ }^{46} \mathrm{Sc}$ measurements detected ${ }^{46} \mathrm{Sc}$ and the ${ }^{46} \mathrm{Sc}$ measurement had an uncertainty of $8 \%$. No data were obtained for ${ }^{93 \mathrm{~m}} \mathrm{Nb}$ or ${ }^{59} \mathrm{Fe}$. Detection of ${ }^{93 \mathrm{~m}} \mathrm{Nb}$ requires measuring a low-energy $\mathrm{x}$-ray. To do so, the wire must be dissolved and deposited on a very thin film prior to counting, but this dissolution was not performed for AGC-2. ${ }^{59} \mathrm{Fe}$ data appear to have been lost since about 17 half-lives elapsed between the end of irradiation on May 5, 2012, and the measurements that were performed in June and July 2014.

\subsection{Spectral Adjustment Uncertainties}

A series of corrections were applied to the measured activation product inventories in the SigPhi calculator to obtain saturated $\sigma \varphi$ values [14]. Gamma self-absorption reduced the measured activity by about $1 \%$ for both wires and neutron burnup varied from 3 to $8 \%$ depending on position. In addition to the corrections determined by the SigPhi calculator and ancillary codes in the STAYSL Pacific Northwest National Laboratory (PNNL) suite, we applied one additional correction to account for shielding from the vanadium capsule (i.e., the AGC-2 flux wires were not removed from this capsule prior to counting because they were at PNNL for AGC-1) [14]. Using the estimated average thickness of the capsule that was based on its size and mass ( 0.01 in.) and mass attenuation coefficients for vanadium at the appropriate incident gamma energy, this is also an approximate $1 \%$ effect. 
The computed $\sigma \varphi$ values were provided to STAYSL PNNL, along with a height-averaged MCNP spectrum, and the cross-section data distributed with the code. Because overall uncertainty in the MCNP value was not known, we used the values in Table 6, based on past precedent alone [15]. The resulting fast fluences were plotted versus height in Figure 11.

Table 6. MCNP uncertainties input to STAYSL PNNL.

\begin{tabular}{|c|c|c|}
\hline \multicolumn{2}{|c|}{ Energy $(\mathrm{MeV})$} & Uncertainty \\
\hline Lower & Upper & - \\
\hline - & $9.9 \mathrm{e}-11$ & $90 \%$ \\
\hline $9.9 \mathrm{e}-11$ & $1.0 \mathrm{e}-3$ & $30 \%$ \\
\hline $1.0 \mathrm{e}-3$ & $1.0 \mathrm{e}-2$ & $20 \%$ \\
\hline $1.0 \mathrm{e}-2$ & 1.5 & $15 \%$ \\
\hline 1.5 & 20.1 & $15 \%$ \\
\hline
\end{tabular}

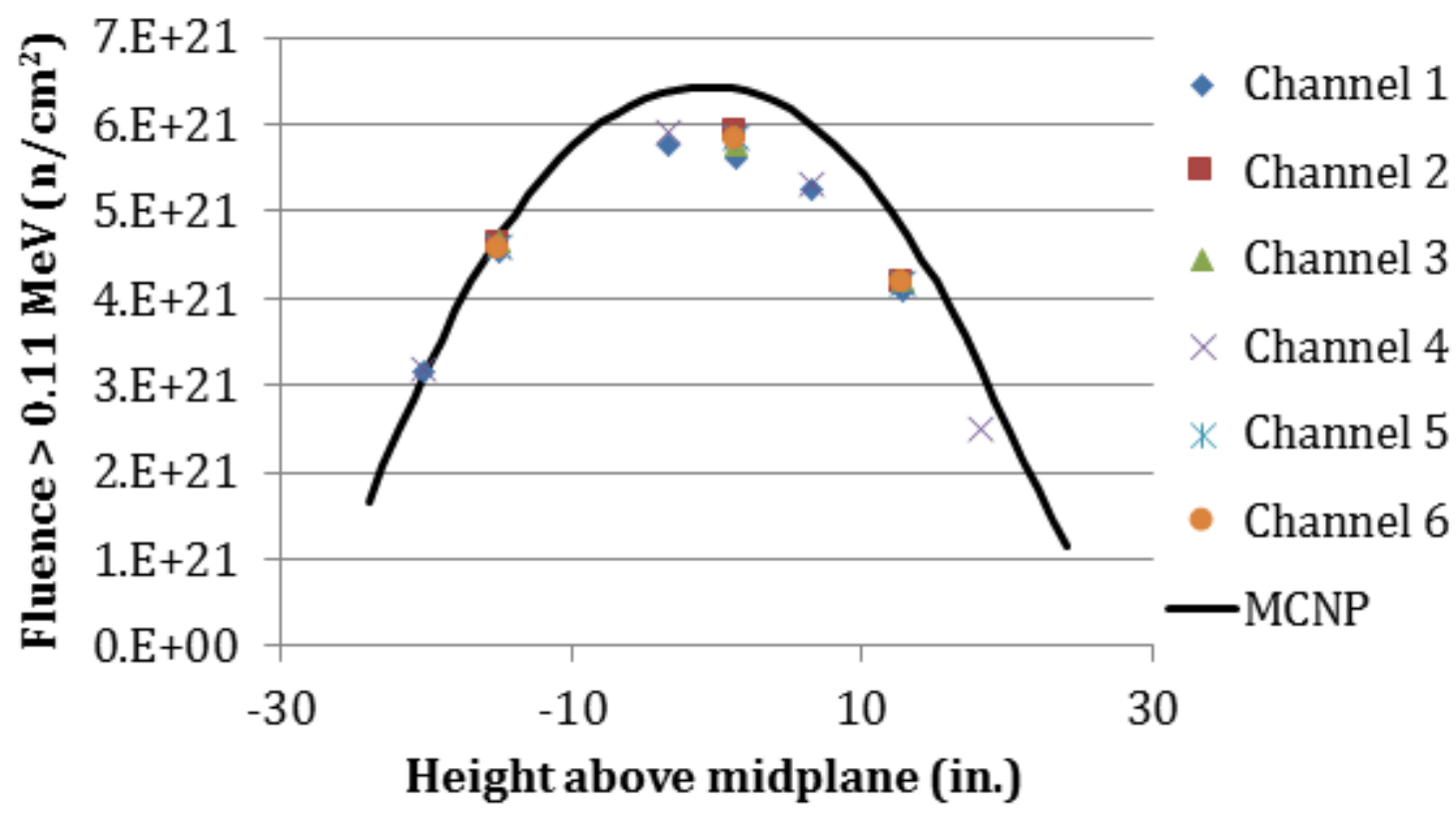

Figure 11. Fast fluence versus position as determined from AGC-2 flux wire analysis and comparison with pre-test MCNP predictions [12].

\subsection{Monte Carlo N Particle/ORIGEN Model Uncertainties}

The uncertainty of the determined fast fluence within the graphite samples was dominated by model uncertainty. The MCNP input consisted of a very large number of parameters that included the reactor geometry, material loadings, and operational data such as power, control drum, and neck shim positions. These parameters contained approximations or measurement uncertainties such that the relevant outputs were uncertain. Furthermore, the actual calculation process was Monte Carlo based, which added another source of uncertainty. Table 7 lists relevant model inputs with their estimated impact on final results. The relevant output for these studies will be the energy-dependent axial flux in each of the graphite samples within the AGC experiment.

Model uncertainty arises from model approximations and measurement uncertainties. Specifically, model approximations can lead to biases in the neutron flux (energy and space dependent). For example, modeling the fuel assemblies as homogenized regions could increase resonance capture rates, reducing 
the thermal flux (i.e., increasing the fast flux), which leads to the experiment interacting with the wrong energy dependence in the flux. Furthermore, as-run power measurements are used to normalize lobe powers. These lobe powers determine the normalization factors for the flux within the AGC experiment and are inputs for fuel burnup calculations. The normalization factors contribute directly to result uncertainties and the fuel burnup calculations can indirectly affect results.

Table 7. Model uncertainties sources.

\begin{tabular}{|c|c|c|}
\hline Model Input & Notional Impact on Results & \begin{tabular}{|l} 
Notes \\
\end{tabular} \\
\hline $\begin{array}{l}\text { Explicit modeling of fuel } \\
\text { geometry }\end{array}$ & Low & $\begin{array}{l}\text { Local flux possibly not captured } \\
\text { by homogenization }\end{array}$ \\
\hline $\begin{array}{l}\text { Estimated source used instead of } \\
\text { eigenvalue flux }\end{array}$ & Low & $\begin{array}{l}\text { Increased uncertainty introduced } \\
\text { through burnup }\end{array}$ \\
\hline $\begin{array}{l}\text { Control element positions near } \\
\text { the experiment }\end{array}$ & Medium & Large changes in flux possible \\
\hline Material temperatures & Low & $\begin{array}{l}\text { Doppler broadening in } \\
\text { cross sections }\end{array}$ \\
\hline Fuel loading & Medium & $\begin{array}{l}\text { Fresh fuel and fission product } \\
\text { buildup }\end{array}$ \\
\hline $\begin{array}{l}\text { Tally normalization factors } \\
\text { (Q-value) }\end{array}$ & Low & $\begin{array}{l}\text { Total energy from fission } \\
\text { difficult to know exactly }\end{array}$ \\
\hline Random number seed & Medium & $\begin{array}{l}\text { Single Monte Carlo calculations } \\
\text { tend to underpredict result } \\
\text { uncertainties }\end{array}$ \\
\hline Nuclear data & Low & $\begin{array}{l}\text { Physical neutron interaction data } \\
\text { contain uncertainties }\end{array}$ \\
\hline As-run power measurements & Medium & $\begin{array}{l}\text { Difficult to measure lobe } \\
\text { powers; detectors have inherent } \\
\text { uncertainty }\end{array}$ \\
\hline
\end{tabular}

Key:

Low: 0 to $5 \%$ Medium: 5 to $10 \%$

\subsection{Future Work}

While uncertainties for both the flux wire measurements and cross sections are readily available, it is more difficult to estimate it for the MCNP input spectrum. This includes not only statistical uncertainty inherent in the Monte Carlo calculation, but any other error resulting from simplifications in geometry. Therefore, the total MCNP uncertainty is difficult to quantify; our present conservative estimate is that it is large relative to the other sources of error and, therefore, contributes disproportionately to the overall error in the radiation damage estimate. For this reason, it is of interest to assess the MCNP uncertainty in a more rigorous and quantitative way.

Currently, no uncertainties are tracked or calculated. It is not possible to track uncertainty through the calculations given the current computer programs, without drastic modifications to the codes. It is possible to calculate the effects of model inputs on model outputs, but this is not currently performed because of limited resources and lack of proper methodology. Though uncertainties in results are not calculated, it is known that uncertainties exist and must be estimated. To accomplish this, an estimated factor that is based loosely on expert opinion is used. A future objective is to quantify this uncertainty based on actual input uncertainty. 


\section{THERMAL ANALYSIS}

A finite element, steady-state heat transfer analysis of the AGC-2 test train was performed using ABAQUS software. This analysis, documented in ECAR-2322 [16], calculated an elevational temperature for each specimen stack at a minimum of three selected times in each reactor cycle. These calculation points were derived from reactor power data, helium-argon gas gap flows through the specimen stacks, as-run heating rates, and as-run graphite dose (i.e., dpa) values. Only a summary of how the average specimen temperature was calculated is contained here. ECAR-2322 describes the model in greater detail; therefore, the reader who requires a technical and complete understanding of the specimen temperature determination should refer to the ECAR.

Figure 12 shows the measured thermocouple temperatures over the course of the experiment. Analyses were conducted on correlations between thermocouple temperatures and differences between thermocouple temperatures to look for trends and step changes that might indicate thermocouple degradation or drift. Correlation analysis was used to identify instances when thermocouples form short circuits (referred to as virtual junctions), which result in thermocouples reporting temperatures from some location in the capsule other than the location where they are intended to read. No evidence was found for virtual junctions. Control charts for differences between thermocouples were used to identify instances when one thermocouple changes its behavior relative to the other thermocouples. No instances were found where a thermocouple significantly and uniformly changed behavior relative to the other thermocouples [17].

Because of the fact that no thermocouple drift was identified, the parameters of the thermal model were adjusted to minimize the difference between the measured thermocouple values and calculated temperatures. After the final adjustments to the model were made, temperatures were calculated at 57 distinct elevations for Stacks 1 through 6 and 170 elevations for Stack 7 on 3 or 4 selected days in every cycle. Figure 13 shows the results of the calculated temperatures from the model versus the thermocouple measurements for TC-01 for all of the reactor cycles.

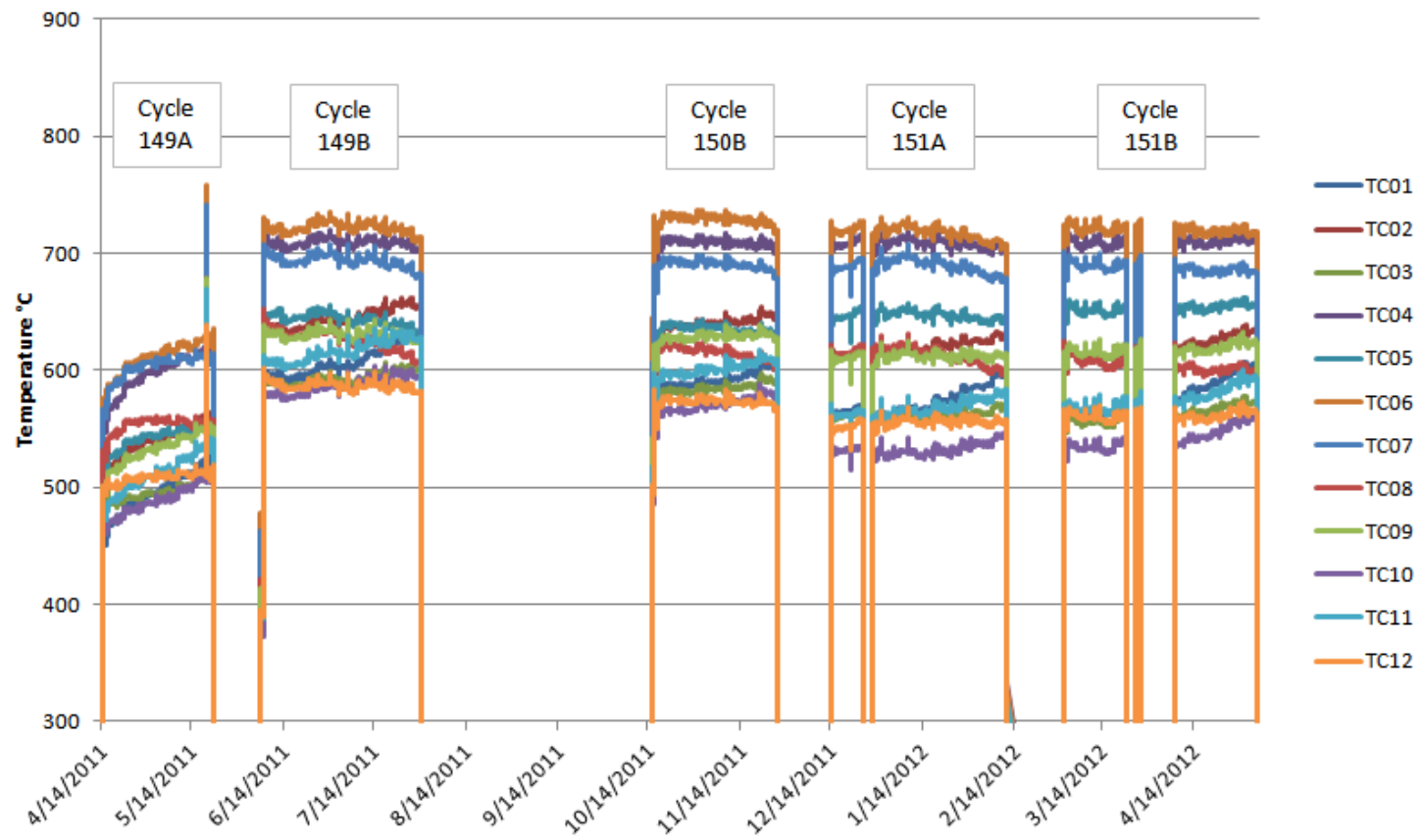

Figure 12. Time history of thermocouple data during the AGC-2 capsule. 


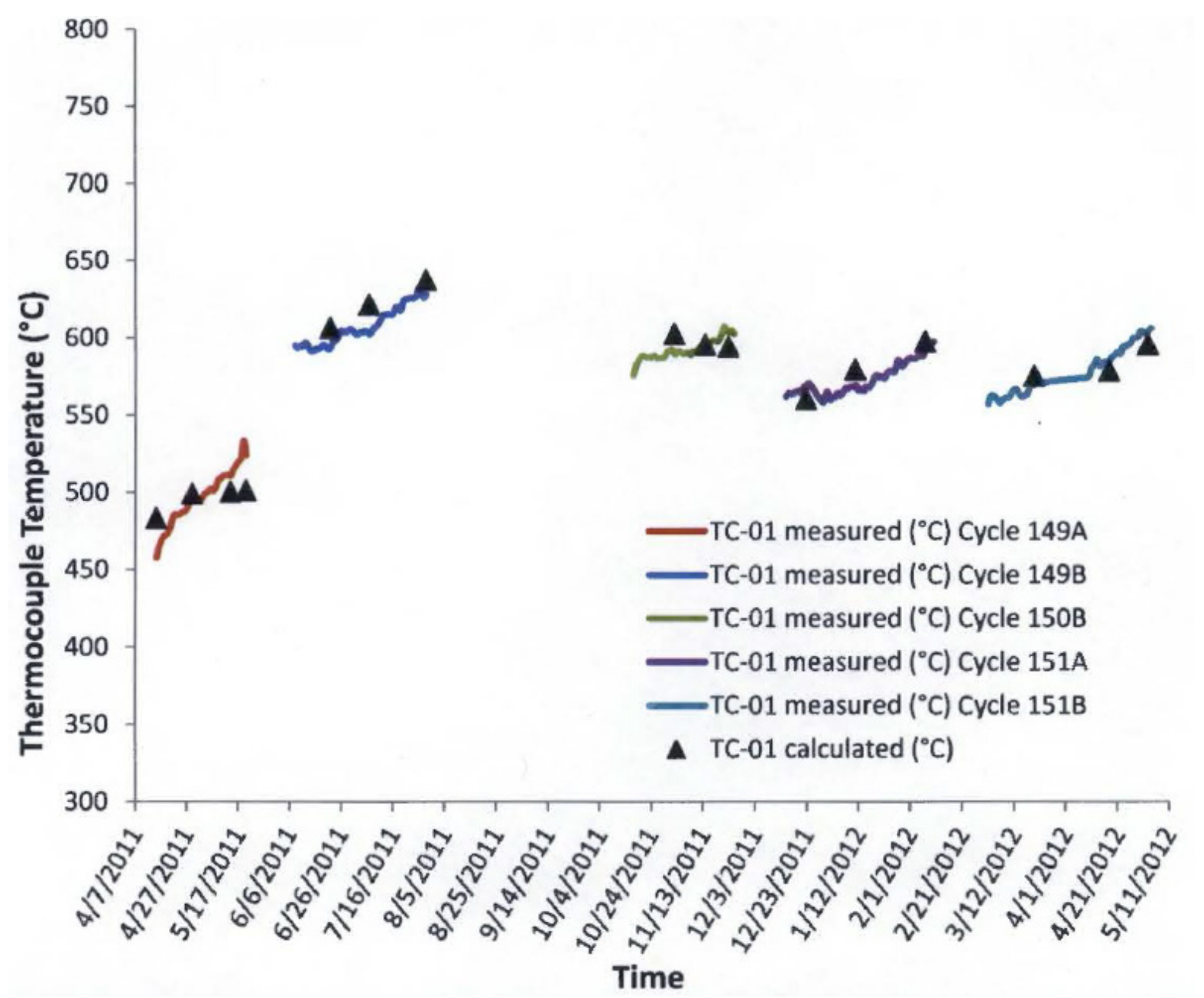

Figure 13. Measured and calculated temperature of TC-01 during all irradiation cycles.

Using the calculated output temperatures of the thermal model, average temperature curves for every specimen stack were computed for each of the reactor cycles. Curve fits were then applied to each of the stack's cycle averages (Figure 14). This resulted in 35 sets of curve fit coefficients (seven stacks times five reactor cycles). Ninth order polynomials were used for each of the stacks:

$T=a_{9} x^{9}+a_{8} x^{8}+a_{7} x^{7}+a_{6} x^{6}+a_{5} x^{5}+a_{4} x^{4}+a_{3} x^{3}+a_{2} x^{2}+a_{1} x+a_{0}$,

where

$$
\begin{aligned}
& \mathrm{T}=\text { temperature }\left({ }^{\circ} \mathrm{C}\right) \\
& \mathrm{x}=\text { elevation (inches) } \\
& \mathrm{a}_{9}-\mathrm{a}_{0}=\text { curve fit coefficients (shown in Table } 8 \text { ). }
\end{aligned}
$$



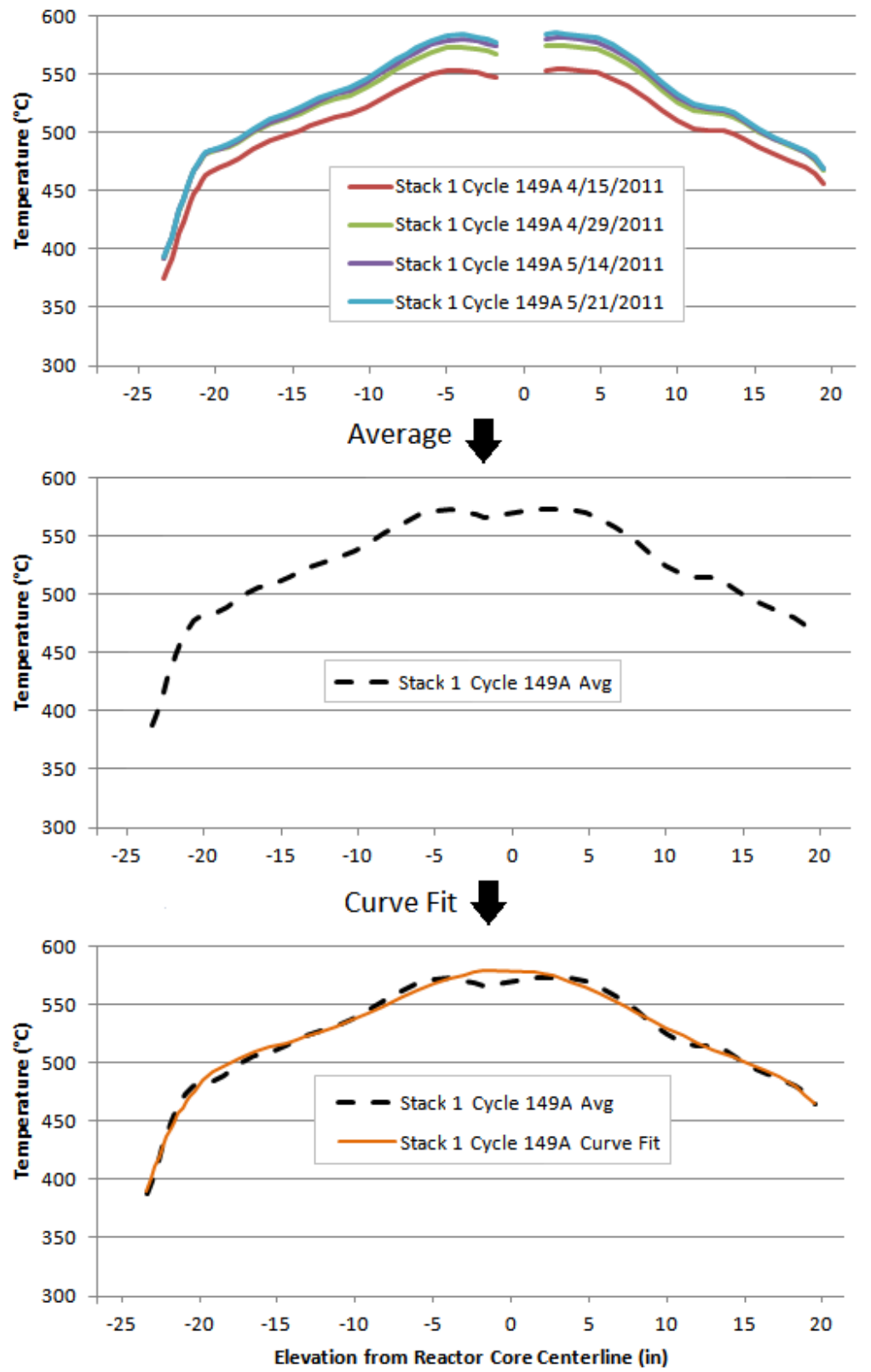

Figure 14. Stack 1, Cycle 149A temperature averaging and curve fit.

Higher order curve fit polynomials were needed in particular for Stack 7, where there is a dramatic temperature increase in the upper elevations (i.e., greater than 17 inches) of the stack. This increase was due to a tungsten heat generation cap incorporated into the design. Table 8 shows the curve fit coefficients for each cycle and each stack.

The 35 curve fits were used to evaluate temperature for every specimen's mid-cycle positions that were given in ECAR-2549 [12]. Thus, for every specimen, a temperature value was calculated for each of the cycles. To obtain an estimation of a specimen's temperature over the entire duration of the experiment, the cycle temperatures were weighted by the number of MW-days and averaged. The complete averaging scheme is summarized in Figure 15. 
Table 8. Temperature curve fit coefficients for each cycle and stack.

\begin{tabular}{|c|c|c|c|c|c|c|c|c|c|c|c|}
\hline Cycle & $\begin{array}{c}\text { Stack } \\
\text { No. } \\
\end{array}$ & a9 & a8 & a7 & a6 & a5 & $\mathbf{a} 4$ & a3 & a2 & a1 & a0 \\
\hline $149 \mathrm{~A}$ & 1 & $1.3146 \mathrm{E}-10$ & $-8.3862 \mathrm{E}-09$ & $-2.1831 \mathrm{E}-07$ & 4.8767E-06 & $9.7711 \mathrm{E}-05$ & $-2.7462 \mathrm{E}-04$ & $-1.4573 \mathrm{E}-02$ & $-4.0454 \mathrm{E}-01$ & $9.5588 \mathrm{E}-02$ & $5.7592 \mathrm{E}+02$ \\
\hline $149 \mathrm{~A}$ & 2 & $8.4941 \mathrm{E}-11$ & $-9.5547 \mathrm{E}-09$ & $-1.7345 \mathrm{E}-07$ & $5.8863 \mathrm{E}-06$ & $8.2300 \mathrm{E}-05$ & $-5.5053 \mathrm{E}-04$ & $-1.2691 \mathrm{E}-02$ & $-3.7893 \mathrm{E}-01$ & $1.0567 \mathrm{E}-01$ & $5.7447 \mathrm{E}+02$ \\
\hline $149 \mathrm{~A}$ & 3 & $1.6859 \mathrm{E}-11$ & $-1.0754 \mathrm{E}-08$ & $-1.0451 \mathrm{E}-07$ & $6.9909 \mathrm{E}-06$ & $5.9688 \mathrm{E}-05$ & $-8.7308 \mathrm{E}-04$ & $-1.0534 \mathrm{E}-02$ & $-3.4968 \mathrm{E}-01$ & $1.8837 \mathrm{E}-01$ & $5.7437 \mathrm{E}+02$ \\
\hline $149 \mathrm{~A}$ & 4 & $1.3957 \mathrm{E}-11$ & $-1.0091 \mathrm{E}-08$ & $-9.3336 \mathrm{E}-08$ & $6.4022 \mathrm{E}-06$ & $5.4361 \mathrm{E}-05$ & $-6.8893 \mathrm{E}-04$ & $-1.0150 \mathrm{E}-02$ & $-3.7321 \mathrm{E}-01$ & $2.6518 \mathrm{E}-01$ & $5.7554 \mathrm{E}+02$ \\
\hline $149 \mathrm{~A}$ & 5 & $5.4585 \mathrm{E}-11$ & $-9.1003 \mathrm{E}-09$ & $-1.3064 \mathrm{E}-07$ & $5.4458 \mathrm{E}-06$ & $6.4875 \mathrm{E}-05$ & $-3.6285 \mathrm{E}-04$ & $-1.0631 \mathrm{E}-02$ & $-4.2151 \mathrm{E}-01$ & $1.3126 \mathrm{E}-01$ & $5.7875 \mathrm{E}+02$ \\
\hline $149 \mathrm{~A}$ & 6 & $9.3398 \mathrm{E}-11$ & $-8.8380 \mathrm{E}-09$ & $-1.7707 \mathrm{E}-07$ & $5.2633 \mathrm{E}-06$ & $8.2844 \mathrm{E}-05$ & $-3.5106 \mathrm{E}-04$ & $-1.2659 \mathrm{E}-02$ & $-4.1520 \mathrm{E}-01$ & 4.4961E-02 & $5.7941 \mathrm{E}+02$ \\
\hline $149 \mathrm{~A}$ & 7 & $2.3061 \mathrm{E}-10$ & $-1.1160 \mathrm{E}-09$ & $-5.0643 \mathrm{E}-08$ & 3.4387E-06 & $4.0181 \mathrm{E}-06$ & $-6.8585 \mathrm{E}-04$ & $-2.3502 \mathrm{E}-03$ & $-3.6765 \mathrm{E}-01$ & $-1.3264 \mathrm{E}-01$ & $6.0362 \mathrm{E}+02$ \\
\hline 149B & 1 & $5.6549 \mathrm{E}-10$ & $8.4266 \mathrm{E}-09$ & $-6.4638 \mathrm{E}-07$ & $-1.2118 \mathrm{E}-05$ & 2.6964E-04 & $5.2340 \mathrm{E}-03$ & $-4.9410 \mathrm{E}-02$ & $-9.8682 \mathrm{E}-01$ & $3.4204 \mathrm{E}+00$ & $6.8894 \mathrm{E}+02$ \\
\hline 149B & 2 & $5.1215 \mathrm{E}-10$ & $7.0708 \mathrm{E}-09$ & $-5.9506 \mathrm{E}-07$ & $-1.0946 \mathrm{E}-05$ & $2.5198 \mathrm{E}-04$ & 4.9135E-03 & $-4.7213 \mathrm{E}-02$ & $-9.5721 \mathrm{E}-01$ & $3.4214 \mathrm{E}+00$ & $6.8732 \mathrm{E}+02$ \\
\hline 149B & 3 & $4.3986 \mathrm{E}-10$ & $5.8029 \mathrm{E}-09$ & $-5.2108 \mathrm{E}-07$ & $-9.7673 \mathrm{E}-06$ & $2.2740 \mathrm{E}-04$ & 4.5664E-03 & $-4.4820 \mathrm{E}-02$ & $-9.2569 \mathrm{E}-01$ & $3.5101 \mathrm{E}+00$ & $6.8726 \mathrm{E}+02$ \\
\hline 149B & 4 & 4.3641E-10 & $6.5322 \mathrm{E}-09$ & $-5.0849 \mathrm{E}-07$ & $-1.0412 \mathrm{E}-05$ & $2.2148 \mathrm{E}-04$ & 4.7667E-03 & $-4.4414 \mathrm{E}-02$ & $-9.5111 \mathrm{E}-01$ & $3.5989 \mathrm{E}+00$ & $6.8856 \mathrm{E}+02$ \\
\hline 149B & 5 & $4.8269 \mathrm{E}-10$ & 7.6862E-09 & $-5.5062 \mathrm{E}-07$ & $-1.1517 \mathrm{E}-05$ & $2.3331 \mathrm{E}-04$ & $5.1397 \mathrm{E}-03$ & $-4.4973 \mathrm{E}-02$ & $-1.0057 \mathrm{E}+00$ & $3.4529 \mathrm{E}+00$ & $6.9216 \mathrm{E}+02$ \\
\hline 149B & 6 & $5.2684 \mathrm{E}-10$ & $8.0568 \mathrm{E}-09$ & $-6.0268 \mathrm{E}-07$ & $-1.1793 \mathrm{E}-05$ & $2.5333 \mathrm{E}-04$ & $5.1754 \mathrm{E}-03$ & $-4.7239 \mathrm{E}-02$ & $-1.0011 \mathrm{E}+00$ & $3.3598 \mathrm{E}+00$ & $6.9296 \mathrm{E}+02$ \\
\hline 149B & 7 & $1.0790 \mathrm{E}-09$ & $2.9046 \mathrm{E}-08$ & $-6.3174 \mathrm{E}-07$ & $-2.1043 \mathrm{E}-05$ & $1.7428 \mathrm{E}-04$ & $6.0722 \mathrm{E}-03$ & $-3.2962 \mathrm{E}-02$ & $-1.0144 \mathrm{E}+00$ & $2.9507 \mathrm{E}+00$ & $7.2054 \mathrm{E}+02$ \\
\hline $150 \mathrm{~B}$ & 1 & $1.4590 \mathrm{E}-09$ & $3.4221 \mathrm{E}-08$ & $-1.3346 \mathrm{E}-06$ & $-3.4330 \mathrm{E}-05$ & $4.2715 \mathrm{E}-04$ & $1.1554 \mathrm{E}-02$ & $-5.7273 \mathrm{E}-02$ & $-1.6759 \mathrm{E}+00$ & $2.2452 \mathrm{E}+00$ & $7.0642 \mathrm{E}+02$ \\
\hline $150 \mathrm{~B}$ & 2 & $1.4046 \mathrm{E}-09$ & $3.2825 \mathrm{E}-08$ & $-1.2825 \mathrm{E}-06$ & $-3.3126 \mathrm{E}-05$ & 4.0929E-04 & $1.1225 \mathrm{E}-02$ & $-5.5052 \mathrm{E}-02$ & $-1.6453 \mathrm{E}+00$ & $2.2459 \mathrm{E}+00$ & $7.0476 \mathrm{E}+02$ \\
\hline $150 \mathrm{~B}$ & 3 & $1.3329 \mathrm{E}-09$ & 3.1587E-08 & $-1.2086 \mathrm{E}-06$ & $-3.1965 \mathrm{E}-05$ & $3.8464 \mathrm{E}-04$ & $1.0881 \mathrm{E}-02$ & $-5.2651 \mathrm{E}-02$ & $-1.6139 \mathrm{E}+00$ & $2.3359 \mathrm{E}+00$ & $7.0470 \mathrm{E}+02$ \\
\hline $150 \mathrm{~B}$ & 4 & 1.3292E-09 & $3.2304 \mathrm{E}-08$ & $-1.1960 \mathrm{E}-06$ & $-3.2605 \mathrm{E}-05$ & $3.7878 \mathrm{E}-04$ & $1.1082 \mathrm{E}-02$ & $-5.2241 \mathrm{E}-02$ & $-1.6395 \mathrm{E}+00$ & $2.4231 \mathrm{E}+00$ & $7.0603 \mathrm{E}+02$ \\
\hline $150 \mathrm{~B}$ & 5 & $1.3752 \mathrm{E}-09$ & $3.3441 \mathrm{E}-08$ & $-1.2384 \mathrm{E}-06$ & $-3.3705 \mathrm{E}-05$ & $3.9086 \mathrm{E}-04$ & $1.1457 \mathrm{E}-02$ & $-5.2855 \mathrm{E}-02$ & $-1.6949 \mathrm{E}+00$ & $2.2800 \mathrm{E}+00$ & $7.0967 \mathrm{E}+02$ \\
\hline $150 \mathrm{~B}$ & 6 & $1.4208 \mathrm{E}-09$ & 3.3831E-08 & $-1.2919 \mathrm{E}-06$ & $-3.3993 \mathrm{E}-05$ & 4.1139E-04 & $1.1494 \mathrm{E}-02$ & $-5.5196 \mathrm{E}-02$ & $-1.6902 \mathrm{E}+00$ & $2.1892 \mathrm{E}+00$ & $7.1046 \mathrm{E}+02$ \\
\hline $150 \mathrm{~B}$ & 7 & $2.1761 \mathrm{E}-09$ & $6.2132 \mathrm{E}-08$ & $-1.4014 \mathrm{E}-06$ & $-4.7707 \mathrm{E}-05$ & 3.3334E-04 & $1.3217 \mathrm{E}-02$ & $-3.9295 \mathrm{E}-02$ & $-1.7503 \mathrm{E}+00$ & $1.7175 \mathrm{E}+00$ & $7.3869 \mathrm{E}+02$ \\
\hline $151 \mathrm{~A}$ & 1 & 7.3657E-10 & $1.2433 \mathrm{E}-08$ & $-8.0189 \mathrm{E}-07$ & $-1.5362 \mathrm{E}-05$ & $3.2339 \mathrm{E}-04$ & $6.3659 \mathrm{E}-03$ & $-5.6999 \mathrm{E}-02$ & $-1.2615 \mathrm{E}+00$ & $3.3325 \mathrm{E}+00$ & $6.8639 \mathrm{E}+02$ \\
\hline $151 \mathrm{~A}$ & 2 & $6.8483 \mathrm{E}-10$ & $1.1140 \mathrm{E}-08$ & $-7.5194 \mathrm{E}-07$ & $-1.4247 \mathrm{E}-05$ & $3.0615 \mathrm{E}-04$ & $6.0614 \mathrm{E}-03$ & $-5.4857 \mathrm{E}-02$ & $-1.2334 \mathrm{E}+00$ & $3.3326 \mathrm{E}+00$ & $6.8485 \mathrm{E}+02$ \\
\hline $151 \mathrm{~A}$ & 3 & $6.1225 \mathrm{E}-10$ & $9.8486 \mathrm{E}-09$ & $-6.7851 \mathrm{E}-07$ & $-1.3055 \mathrm{E}-05$ & $2.8203 \mathrm{E}-04$ & $5.7118 \mathrm{E}-03$ & $-5.2523 \mathrm{E}-02$ & $-1.2014 \mathrm{E}+00$ & $3.4173 \mathrm{E}+00$ & $6.8477 \mathrm{E}+02$ \\
\hline $151 \mathrm{~A}$ & 4 & $6.0928 \mathrm{E}-10$ & $1.0552 \mathrm{E}-08$ & $-6.6684 \mathrm{E}-07$ & $-1.3677 \mathrm{E}-05$ & $2.7653 \mathrm{E}-04$ & $5.9058 \mathrm{E}-03$ & $-5.2165 \mathrm{E}-02$ & $-1.2261 \mathrm{E}+00$ & $3.5045 \mathrm{E}+00$ & $6.8603 \mathrm{E}+02$ \\
\hline $151 \mathrm{~A}$ & 5 & $6.5682 \mathrm{E}-10$ & $1.1714 \mathrm{E}-08$ & $-7.1036 \mathrm{E}-07$ & $-1.4789 \mathrm{E}-05$ & $2.8888 \mathrm{E}-04$ & $6.2792 \mathrm{E}-03$ & $-5.2819 \mathrm{E}-02$ & $-1.2800 \mathrm{E}+00$ & $3.3683 \mathrm{E}+00$ & $6.8949 \mathrm{E}+02$ \\
\hline $151 \mathrm{~A}$ & 6 & $6.9784 \mathrm{E}-10$ & $1.2027 \mathrm{E}-08$ & $-7.5905 \mathrm{E}-07$ & $-1.5013 \mathrm{E}-05$ & $3.0769 \mathrm{E}-04$ & $6.3009 \mathrm{E}-03$ & $-5.4950 \mathrm{E}-02$ & $-1.2744 \mathrm{E}+00$ & $3.2791 \mathrm{E}+00$ & $6.9025 \mathrm{E}+02$ \\
\hline $151 \mathrm{~A}$ & 7 & 1.3542E-09 & $3.6983 \mathrm{E}-08$ & $-8.4615 \mathrm{E}-07$ & $-2.7143 \mathrm{E}-05$ & $2.3601 \mathrm{E}-04$ & 7.8434E-03 & $-4.0726 \mathrm{E}-02$ & $-1.3332 \mathrm{E}+00$ & $2.9024 \mathrm{E}+00$ & $7.1732 \mathrm{E}+02$ \\
\hline 151B & 1 & $7.5186 \mathrm{E}-10$ & $1.4289 \mathrm{E}-08$ & $-8.4959 \mathrm{E}-07$ & $-1.7260 \mathrm{E}-05$ & $3.7000 \mathrm{E}-04$ & $6.9942 \mathrm{E}-03$ & $-7.3478 \mathrm{E}-02$ & $-1.3430 \mathrm{E}+00$ & $5.1506 \mathrm{E}+00$ & $6.9588 \mathrm{E}+02$ \\
\hline $151 \mathrm{~B}$ & 2 & $6.9824 \mathrm{E}-10$ & $1.2979 \mathrm{E}-08$ & $-7.9750 \mathrm{E}-07$ & $-1.6127 \mathrm{E}-05$ & $3.5197 \mathrm{E}-04$ & $6.6843 \mathrm{E}-03$ & $-7.1223 \mathrm{E}-02$ & $-1.3144 \mathrm{E}+00$ & $5.1453 \mathrm{E}+00$ & $6.9433 \mathrm{E}+02$ \\
\hline 151B & 3 & $6.2742 \mathrm{E}-10$ & $1.1705 \mathrm{E}-08$ & $-7.2583 \mathrm{E}-07$ & $-1.4950 \mathrm{E}-05$ & $3.2844 \mathrm{E}-04$ & $6.3395 \mathrm{E}-03$ & $-6.8963 \mathrm{E}-02$ & $-1.2831 \mathrm{E}+00$ & $5.2316 \mathrm{E}+00$ & $6.9427 \mathrm{E}+02$ \\
\hline
\end{tabular}


Table 8. (continued).

\begin{tabular}{|c|c|c|c|c|c|c|c|c|c|c|c|}
\hline Cycle & $\begin{array}{c}\text { Stack } \\
\text { No. } \\
\end{array}$ & a9 & a8 & a7 & a6 & a5 & a4 & a3 & a2 & a1 & a0 \\
\hline 151B & 4 & $6.2268 \mathrm{E}-10$ & $1.2356 \mathrm{E}-08$ & $-7.1308 \mathrm{E}-07$ & $-1.5534 \mathrm{E}-05$ & $3.2273 \mathrm{E}-04$ & $6.5240 \mathrm{E}-03$ & $-6.8579 \mathrm{E}-02$ & $-1.3068 \mathrm{E}+00$ & $5.3169 \mathrm{E}+00$ & $6.9551 \mathrm{E}+02$ \\
\hline $151 \mathrm{~B}$ & 5 & $6.6862 \mathrm{E}-10$ & $1.3502 \mathrm{E}-08$ & $-7.5476 \mathrm{E}-07$ & $-1.6630 \mathrm{E}-05$ & $3.3439 \mathrm{E}-04$ & $6.8923 \mathrm{E}-03$ & $-6.9145 \mathrm{E}-02$ & $-1.3602 \mathrm{E}+00$ & $5.1791 \mathrm{E}+00$ & $6.9895 \mathrm{E}+02$ \\
\hline $151 \mathrm{~B}$ & 6 & $7.1447 \mathrm{E}-10$ & $1.3933 \mathrm{E}-08$ & $-8.0758 \mathrm{E}-07$ & $-1.6949 \mathrm{E}-05$ & $3.5445 \mathrm{E}-04$ & $6.9393 \mathrm{E}-03$ & $-7.1436 \mathrm{E}-02$ & $-1.3567 \mathrm{E}+00$ & $5.0972 \mathrm{E}+00$ & $6.9973 \mathrm{E}+02$ \\
\hline 151B & 7 & $1.4594 \mathrm{E}-09$ & $4.1690 \mathrm{E}-08$ & $-9.3856 \mathrm{E}-07$ & $-3.0912 \mathrm{E}-05$ & $2.8667 \mathrm{E}-04$ & $8.8577 \mathrm{E}-03$ & $-5.6757 \mathrm{E}-02$ & $-1.4415 \mathrm{E}+00$ & $4.6911 \mathrm{E}+00$ & $7.2703 \mathrm{E}+02$ \\
\hline
\end{tabular}




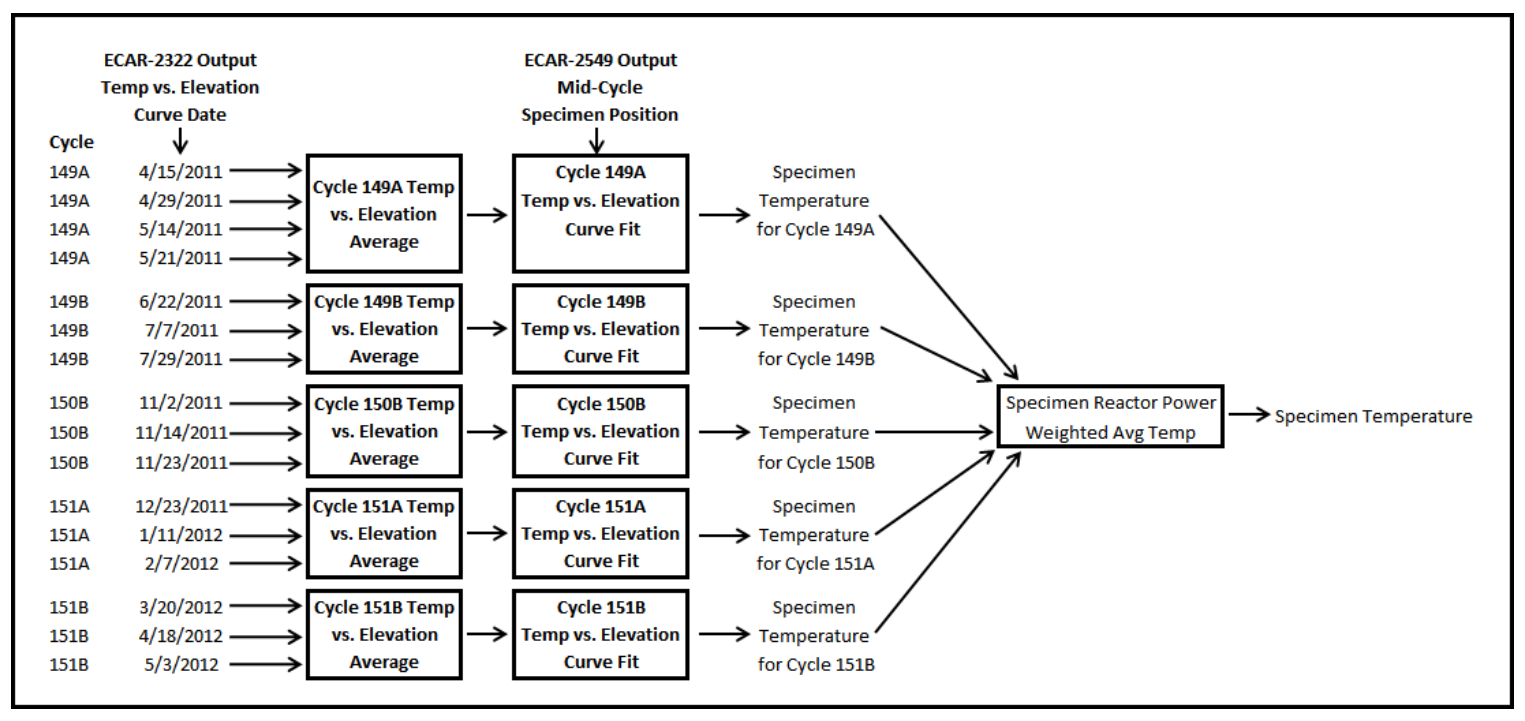

Figure 15. Specimen stack temperature averaging.

The accuracy of the temperature model developed by the ABAQUS software was validated by comparing the calculated temperatures to the thermocouple values measured and recorded in the Nuclear Data Management and Analysis System. In particular, the mean of the temperature difference indicated the bias in the temperature calculation, and the standard deviation of the temperature difference indicated the variability in the temperature calculation. The uncertainty in the calculation was estimated to be equal to:

$\mu \pm 2 \times \sigma$,

where

$$
\begin{aligned}
& \mu=\text { the mean of the temperature difference } \\
& \sigma=\text { the standard deviation of the temperature difference. }
\end{aligned}
$$

Therefore, the maximum uncertainty of the temperature model is $\pm 40^{\circ} \mathrm{C}$. ECAR-3017 provides a complete explanation of the uncertainty calculations of the temperature model [18].

In addition to the uncertainty in the temperature model, the individual specimen temperatures also have error associated with the curve fitting. The curve fitting error was quantified by computing the cumulative deviation of the temperature data from the curve fit line. It is reported here as a percentage with respect to the stack average (across all specimen positions). Overall, these errors were much less than the errors associated with the temperature model (i.e., less than $2 \%$ ). The largest of the curve fitting errors occurred during reactor Cycle 149A and are shown in Table 9.

Table 9. Curve fitting standard deviations for reactor Cycle 149A.

\begin{tabular}{lccc}
\hline & Stack Average $\left({ }^{\circ} \mathbf{C}\right)$ & $\begin{array}{c}\text { Standard Deviation about } \\
\text { the Regression }\left({ }^{\circ} \mathbf{C}\right)\end{array}$ & $\begin{array}{c}\text { Regression Coefficient of } \\
\text { Variance }(\%)\end{array}$ \\
\hline Stack 1 & 510 & 3.55 & 0.70 \\
Stack 2 & 510 & 3.51 & 0.69 \\
Stack 3 & 510 & 3.42 & 0.67 \\
Stack 4 & 510 & 3.39 & 0.67 \\
Stack 5 & 511 & 3.41 & 0.67 \\
Stack 6 & 512 & 3.48 & 0.68 \\
Stack 7 & 549 & 8.40 & 1.53 \\
\hline
\end{tabular}




\section{LOAD ANALYSIS}

All specimens in the upper portions of Stacks 1 through 6 were loaded using pneumatic load cylinders. The nominal loads used for each stack were $400 \mathrm{lbf}$ for Stacks 1 and 4, $500 \mathrm{lbf}$ for Stacks 2 and 5, and $600 \mathrm{lbf}$ for Stacks 3 and 6. These nominal loads equated to stresses of approximately 2,000 psi, 2,500 psi, and 3,000 psi on the 0.5 -in. diameter specimens. Radial irradiation dimensional change was considered to be very small; therefore, any lateral shrinkage or expansion during irradiation was ignored. The matching loads were arranged diametrically opposite in the capsule to minimize eccentric loading on the specimen holders. Load analysis for the AGC-2 capsule was documented in ECAR-2925 [19] and the results are shown in Table 10. Figure 16 shows that the loads were applied relatively constant during the course of irradiation.

Table 10. Load values after application of threshold for each stack.

\begin{tabular}{lcccccc}
\hline & Stack 1 & Stack 2 & Stack 3 & Stack 4 & Stack 5 & Stack 6 \\
\hline Average (lbf) & 406 & 508 & 606 & 395 & 503 & 604 \\
Two times standard deviation (lbf) & 11 & 13 & 12 & 9 & 7 & 10 \\
Coefficient of variance (\%) & 1.3 & 1.3 & 1.0 & 1.1 & 0.7 & 0.8 \\
\hline
\end{tabular}

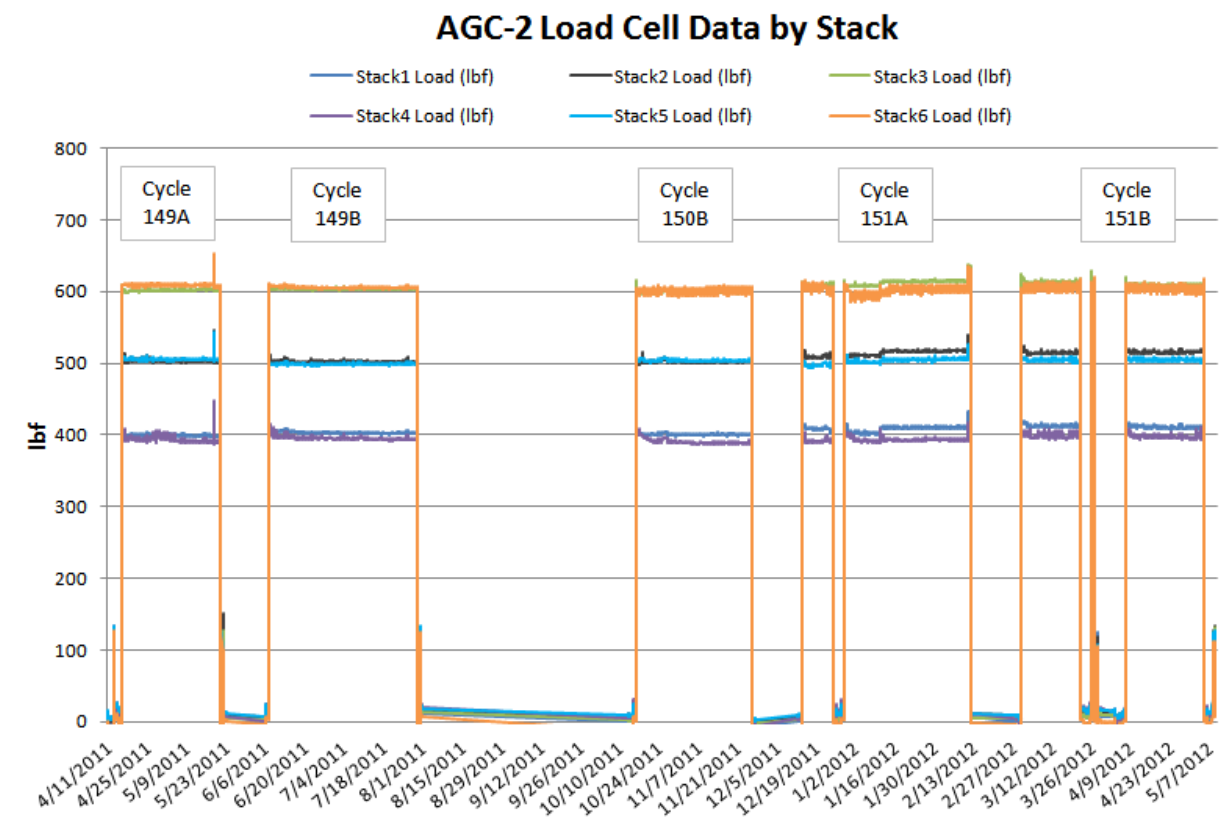

Figure 16. Compressive loads for each specimen stack over the duration of the AGC-2 capsule.

After analyzing the power and load history data, it was determined that there were periods of time (at the start of cycles) where there was reactor power but no load being applied to the stacks. The load averaging (in ECAR-2925 [19]) took this into account by only averaging load data during periods of time when the reactor was outputting power. The logic used for the load calculations was as follows: if the load was greater than $90 \%$ of the nominal load and the reactor power was greater than $2 \mathrm{MW}$, then that data point was included in the average load calculation for the stack.

The precision of the load data was measured by calculating the standard deviation. To compare precision among the stacks with different nominal loads, the coefficient of variation was calculated. The range of these coefficients of variation was between $0.7 \%$ (Stack 5) and $1.3 \%$ (Stacks 1 and 2). The magnitudes of the coefficients of variation were all on the same order, indicating the consistency between 
stack loads and good repeatability with each stack. The accuracy of the data was quantified from the specifications of the load cells used in the experiment. The load cells used have an accuracy of $\pm 0.3 \%$ of full-scale reading. Full scale of the load cells is 1,000 lbf; therefore, the accuracy is $\pm 3 \mathrm{lbf}$.

\section{TABLE OF ADJUSTED DOSE, TEMPERATURE, AND LOAD}

The position of the individual specimens in the reactor changed due to irradiation damage, stress-induced creep, and thermal expansion. Table B-1 through Table B-18, in Appendix B, show the results of the temperature, dose, and load calculations as they correlate to each specimen and its adjusted position in the AGC- 2 capsule. These data reflect the average change in elevation the specimens experienced over the duration of the experiment and will be used in future analysis of AGC-2 creep and property data.

\section{REFERENCES}

[1] ORNL, 2013, AGC-1 Specimen Post Irradiation Data Report, ORNL/TM-2013/242, Oak Ridge National Laboratory, September 2013.

[2] Burchell, T., R. Bratton, and W. Windes, 2007, NGNP Graphite Selection and Acquisition Strategy, ORNL/TM-2007/153, Oak Ridge National Laboratory, September 2007.

[3] Bratton, R. L. and T. D. Burchell, 2005, NGNP Graphite Testing and Qualification Specimen Selection Strategy, INL/EXT-05-00269, Idaho National Laboratory, May 2005.

[4] INL, Graphite Technology Development Plan, INL/EXT-07-13165, Revision 0, Idaho National Laboratory, September 2007.

[5] PLN-2497, 2010, “Graphite Technology Development Plan,” Revision 1, Idaho National Laboratory, October 2010.

[6] TFR-645, 2010, “Advanced Graphite Capsule AGC-2 Experiment Test Train,” Revision 0, July 2010.

[7] DWG 600786, "ATR Advanced Graphite Capsule (AGC-2) Graphite Specimen Machining Details," Revision 2, Idaho National Laboratory, July 9, 2012.

[8] DWG 601256, “Advanced Graphite Capsule 2 (AGC-2) Specimen Stack-Up Arrangements,” Revision 1, Idaho National Laboratory, July 2012.

[9] DWG 601266, “ATR Advanced Graphite Capsule Number 2 (AGC-2) Capsule Facility Assemblies," Revision 2, Idaho National Laboratory, July 2012.

[10] INL, Engineering Work Instructions for Assembling the AGC-2 Experiment, WO 137268-01.

[11] Windes, W. E., P. L. Winston, and W.D. Swank, 2014, AGC-2 Disassembly Report, INL/EXT14-32060, May 2014.

[12] Reed, Ted, “AGC-2 Individual Specimen Position Adjustment,” ECAR-2549, Idaho National Laboratory, June 2016.

[13] Parry, J. R., 2014, “As-Run Physics Analysis for the AGC-2 Experiment Irradiated in the ATR," ECAR-2291, Idaho National Laboratory, March 6, 2014.

[14] L. R. Greenwood and C. D. Johnson, "User Guide for the STAYSL PNNL Suite of Software Tools,” PNNL-22253, February 2013.

[15] Greenwood, L. R., 2012, “Analysis of AGC-1 Neutron Fluence Monitors,” PNNL Project 23747, August 2012. 
[16] Murray, Paul, “As-Run Thermal Analysis Of The AGC-2 Experiment,” ECAR-2322, Idaho National Laboratory, April 2014.

[17] INL, AGC-2 Irradiation Data Qualification Final Report, INL/EXT-12-26248, Idaho National Laboratory, July 2012.

[18] Murray, Paul, "Uncertainty Analysis Of Temperature In The AGC-1 And AGC-2 Experiments," ECAR-3017, Idaho National Laboratory, April 2016.

[19] Rohrbaugh, David, "AGC-2 Specimen Load Calculations by Stack”, ECAR-2925, Idaho National Laboratory, February 2016. 


\section{Appendix A \\ Three-Dimensional Dose Plot}

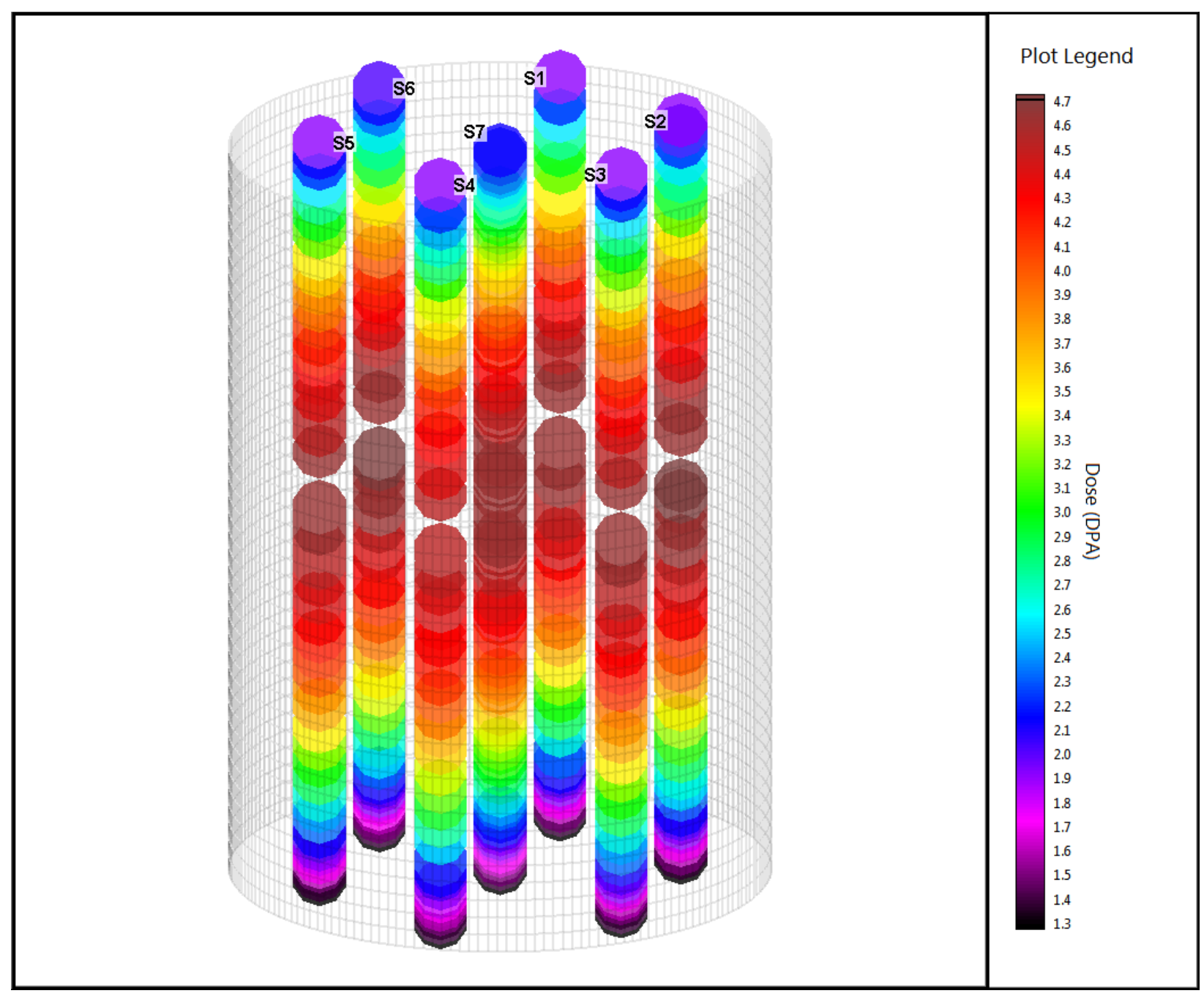

Figure A-1. Three-dimensional plot of the specimen dose as a function of position in the AGC capsule. 


\section{Appendix B \\ Tabulation of Specimen Position, Load, Dose, and Temperature}

Table B-1. Stack 1 compressed.

\begin{tabular}{|c|c|c|c|c|c|c|c|}
\hline $\begin{array}{c}\text { Loading } \\
\text { Order }\end{array}$ & $\begin{array}{c}\text { Specimen } \\
\text { ID }\end{array}$ & Graphite Grade & $\begin{array}{l}\text { Nominal } \\
\text { Specimen } \\
\text { Elevation } \\
\text { (in) }\end{array}$ & $\begin{array}{l}\text { End of Test } \\
\text { Specimen } \\
\text { Elevation } \\
\text { (in) }\end{array}$ & $\begin{array}{c}\text { Specimen } \\
\text { Tempe rature } \\
\left({ }^{\circ} \mathrm{C}\right)\end{array}$ & $\begin{array}{c}\text { Specimen } \\
\text { Dose } \\
\text { (DPA) }\end{array}$ & $\begin{array}{c}\text { Stack Load } \\
\text { (lbf) }\end{array}$ \\
\hline 23 & CW1 01 & $\mathrm{H}-451$ & 19.500 & 18.873 & 541 & 2.0 & 406 \\
\hline 22 & $1 \mathrm{~A}$ & Flux Monitor & 18.875 & 18.259 & 549 & 2.2 & 406 \\
\hline 21 & DW1 01 & PCEA & 18.250 & 17.645 & 556 & 2.3 & 406 \\
\hline 20 & BW1 01 & NBG-18 & 17.250 & 16.662 & 566 & 2.6 & 406 \\
\hline 19 & EW01 02 & IG-110 & 16.250 & 15.681 & 573 & 2.8 & 406 \\
\hline 18 & FW01 01 & IG-430 & 15.250 & 14.701 & 579 & 3.0 & 406 \\
\hline 17 & DW1 02 & PCEA & 14.250 & 13.723 & 583 & 3.2 & 406 \\
\hline 16 & AY & Flux Monitor & 13.625 & 13.111 & 586 & 3.3 & 406 \\
\hline 15 & BW1 02 & NBG-18 & 13.000 & 12.497 & 589 & 3.5 & 406 \\
\hline 14 & FW01 02 & IG-430 & 12.000 & 11.518 & 594 & 3.6 & 406 \\
\hline 13 & EW01 04 & IG-110 & 11.000 & 10.540 & 601 & 3.8 & 406 \\
\hline 12 & DW10 01 & PCEA & 10.000 & 9.566 & 610 & 3.9 & 406 \\
\hline 11 & BW1 03 & NBG-18 & 9.000 & 8.591 & 619 & 4.1 & 406 \\
\hline 10 & FW01 03 & IG-430 & 8.000 & 7.615 & 630 & 4.2 & 406 \\
\hline 9 & $1 \mathrm{H}$ & Flux Monitor & 7.375 & 7.003 & 636 & 4.3 & 406 \\
\hline 8 & CW1 02 & H-451 & 6.750 & 6.395 & 643 & 4.3 & 406 \\
\hline 7 & EW02 01 & IG-110 & 5.750 & 5.424 & 653 & 4.4 & 406 \\
\hline 6 & DW10 02 & PCEA & 4.750 & 4.454 & 662 & 4.5 & 406 \\
\hline 5 & BW10 01 & NBG-18 & 3.750 & 3.482 & 669 & 4.5 & 406 \\
\hline 4 & FW01 04 & IG-430 & 2.750 & 2.506 & 674 & 4.6 & 406 \\
\hline 3 & $8 \mathrm{H}$ & Flux Monitor & 2.125 & 1.895 & 676 & 4.6 & 406 \\
\hline 2 & AW1 01 & NBG-17 & 1.500 & 1.286 & 677 & 4.6 & 406 \\
\hline
\end{tabular}


Table B-2. Stack 1 uncompressed.

\begin{tabular}{|c|c|c|c|c|c|c|c|}
\hline $\begin{array}{l}\text { Loading } \\
\text { Order }\end{array}$ & $\begin{array}{c}\text { Specimen } \\
\text { ID }\end{array}$ & Graphite Grade & $\begin{array}{l}\text { Nominal } \\
\text { Specimen } \\
\text { Elevation } \\
\text { (in) }\end{array}$ & $\begin{array}{l}\text { End of Test } \\
\text { Specimen } \\
\text { Elevation } \\
\text { (in) }\end{array}$ & $\begin{array}{c}\text { Specimen } \\
\text { Temperature } \\
\left({ }^{\circ} \mathrm{C}\right)\end{array}$ & $\begin{array}{c}\text { Specimen } \\
\text { Dose } \\
\text { (DPA) }\end{array}$ & $\begin{array}{l}\text { Stack Load } \\
\text { (lbf) }\end{array}$ \\
\hline 36 & AW1 02 & NBG-17 & -1.750 & -1.530 & 668 & 4.6 & 0 \\
\hline 35 & $\mathrm{AO}$ & Flux Monitor & -2.375 & -2.153 & 664 & 4.6 & 0 \\
\hline 34 & FW02 01 & IG-430 & -3.000 & -2.778 & 659 & 4.6 & 0 \\
\hline 33 & BW10 02 & NBG-18 & -4.000 & -3.777 & 651 & 4.6 & 0 \\
\hline 32 & DW10 03 & PCEA & -5.000 & -4.775 & 642 & 4.5 & 0 \\
\hline 31 & EW02 02 & IG-110 & -6.000 & -5.772 & 633 & 4.5 & 0 \\
\hline 30 & CW1 03 & H-451 & -7.000 & -6.769 & 625 & 4.4 & 0 \\
\hline 29 & AL14 02 & NBG-17 & -7.625 & -7.391 & 621 & 4.4 & 0 \\
\hline 28 & FW02 02 & IG-430 & -8.250 & -8.015 & 616 & 4.3 & 0 \\
\hline 27 & BW10 03 & NBG-18 & -9.250 & -9.014 & 610 & 4.2 & 0 \\
\hline 26 & DW10 04 & PCEA & -10.250 & -10.011 & 605 & 4.1 & 0 \\
\hline 25 & EW02 03 & IG-110 & -11.250 & -11.009 & 601 & 4.0 & 0 \\
\hline 24 & FW02 03 & IG-430 & -12.250 & -12.007 & 598 & 3.9 & 0 \\
\hline 23 & BW11 01 & NBG-18 & -13.250 & -13.006 & 595 & 3.7 & 0 \\
\hline 22 & $8 \mathrm{U}$ & Flux Monitor & -13.875 & -13.631 & 593 & 3.6 & 0 \\
\hline 21 & DW11 01 & PCEA & -14.500 & -14.255 & 591 & 3.5 & 0 \\
\hline 20 & FW02 04 & IG-430 & -15.500 & -15.254 & 587 & 3.3 & 0 \\
\hline 19 & EW02 04 & IG-110 & -16.500 & -16.253 & 582 & 3.1 & 0 \\
\hline 18 & BW11 02 & NBG-18 & -17.500 & -17.252 & 576 & 2.9 & 0 \\
\hline 17 & DW11 02 & PCEA & -18.500 & -18.251 & 568 & 2.7 & 0 \\
\hline 16 & $\mathrm{AE}$ & Flux Monitor & -19.125 & -18.876 & 561 & 2.6 & 0 \\
\hline 15 & CW10 02 & H-451 & -19.750 & -19.501 & 552 & 2.4 & 0 \\
\hline 14 & BP7 06 & NBG-18 & -20.375 & -20.125 & 542 & 2.2 & 0 \\
\hline 13 & L2 08 & PPEA & -20.625 & -20.375 & 537 & 2.2 & 0 \\
\hline 12 & K2 09 & PGX & -20.875 & -20.624 & 532 & 2.1 & 0 \\
\hline 11 & P2-08 & PCIB & -21.125 & -20.874 & 526 & 2.0 & 0 \\
\hline 10 & DW18 03 & PCEA & -21.375 & -21.123 & 519 & 2.0 & 0 \\
\hline 9 & M2-07 & NBG-25 & -21.625 & -21.373 & 512 & 1.9 & 0 \\
\hline 8 & S2 07 & NBG-10 & -21.875 & -21.623 & 504 & 1.8 & 0 \\
\hline 7 & FW15 01 & IG-430 & -22.125 & -21.873 & 496 & 1.8 & 0 \\
\hline 6 & EW14 01 & IG-110 & -22.375 & -22.122 & 486 & 1.7 & 0 \\
\hline 5 & J2 06 & HLM & -22.625 & -22.372 & 476 & 1.6 & 0 \\
\hline 4 & RW2 09 & BAN & -22.875 & -22.622 & 464 & 1.6 & 0 \\
\hline 3 & H562 & A3-3 & -23.125 & -22.871 & 451 & 1.5 & 0 \\
\hline 2 & TP 18 & 2114 & -23.375 & -23.120 & 437 & 1.4 & 0 \\
\hline
\end{tabular}


Table B-3. Stack 2 compressed.

\begin{tabular}{|c|c|c|c|c|c|c|c|}
\hline $\begin{array}{l}\text { Loading } \\
\text { Order }\end{array}$ & $\begin{array}{c}\text { Specimen } \\
\text { ID }\end{array}$ & Graphite Grade & $\begin{array}{c}\text { Nominal } \\
\text { Specimen } \\
\text { Ele vation } \\
\text { (in) }\end{array}$ & $\begin{array}{l}\text { End of Test } \\
\text { Specimen } \\
\text { Elevation } \\
\text { (in) }\end{array}$ & $\begin{array}{c}\text { Specimen } \\
\text { Tempe rature } \\
\left({ }^{\circ} \mathrm{C}\right)\end{array}$ & $\begin{array}{c}\text { Specimen } \\
\text { Dose } \\
\text { (DPA) }\end{array}$ & $\begin{array}{c}\text { Stack Load } \\
\text { (lbf) }\end{array}$ \\
\hline 23 & EW03 01 & IG-110 & 19.500 & 18.656 & 542 & 2.0 & 508 \\
\hline 22 & AW17 07 & NBG-17 & 18.875 & 18.045 & 550 & 2.2 & 508 \\
\hline 21 & FW03 01 & IG-430 & 18.250 & 17.434 & 557 & 2.3 & 508 \\
\hline 20 & DA4 02 & PCEA & 17.250 & 16.461 & 567 & 2.6 & 508 \\
\hline 19 & BP4 02 & NBG-18 & 16.250 & 15.489 & 574 & 2.8 & 508 \\
\hline 18 & AW1 03 & NBG-17 & 15.250 & 14.515 & 579 & 3.0 & 508 \\
\hline 17 & EW03 02 & IG-110 & 14.250 & 13.544 & 583 & 3.2 & 508 \\
\hline 16 & 2B & Flux Monitor & 13.625 & 12.937 & 586 & 3.4 & 508 \\
\hline 15 & DW11 03 & PCEA & 13.000 & 12.331 & 589 & 3.5 & 508 \\
\hline 14 & BW11 03 & NBG-18 & 12.000 & 11.362 & 595 & 3.7 & 508 \\
\hline 13 & CW10 03 & H-451 & 11.000 & 10.394 & 602 & 3.8 & 508 \\
\hline 12 & AW10 01 & NBG-17 & 10.000 & 9.428 & 610 & 4.0 & 508 \\
\hline 11 & EW03 03 & IG-110 & 9.000 & 8.462 & 620 & 4.1 & 508 \\
\hline 10 & DA4 03 & PCEA & 8.000 & 7.499 & 630 & 4.2 & 508 \\
\hline 9 & AW17 08 & NBG-17 & 7.375 & 6.896 & 637 & 4.3 & 508 \\
\hline 8 & BP4 03 & NBG-18 & 6.750 & 6.290 & 643 & 4.3 & 508 \\
\hline 7 & FW03 02 & IG-430 & 5.750 & 5.323 & 653 & 4.4 & 508 \\
\hline 6 & AP4 02 & NBG-17 & 4.750 & 4.355 & 661 & 4.5 & 508 \\
\hline 5 & CW11 01 & H-451 & 3.750 & 3.391 & 668 & 4.6 & 508 \\
\hline 4 & DW11 04 & PCEA & 2.750 & 2.432 & 673 & 4.6 & 508 \\
\hline 3 & 37 & Flux Monitor & 2.125 & 1.830 & 675 & 4.6 & 508 \\
\hline 2 & BW12 01 & NBG-18 & 1.500 & 1.225 & 675 & 4.6 & 508 \\
\hline
\end{tabular}


Table B-4. Stack 2 uncompressed.

\begin{tabular}{|c|c|c|c|c|c|c|c|}
\hline $\begin{array}{l}\text { Loading } \\
\text { Order }\end{array}$ & $\begin{array}{c}\text { Specimen } \\
\text { ID }\end{array}$ & Graphite Grade & $\begin{array}{l}\text { Nominal } \\
\text { Specimen } \\
\text { Elevation } \\
\text { (in) }\end{array}$ & $\begin{array}{l}\text { End of Test } \\
\text { Specimen } \\
\text { Elevation } \\
\text { (in) }\end{array}$ & $\begin{array}{c}\text { Specimen } \\
\text { Temperature } \\
\left({ }^{\circ} \mathrm{C}\right)\end{array}$ & $\begin{array}{c}\text { Specimen } \\
\text { Dose } \\
\text { (DPA) }\end{array}$ & $\begin{array}{l}\text { Stack Load } \\
\text { (lbf) }\end{array}$ \\
\hline 36 & BW12 02 & NBG-18 & -1.750 & -1.612 & 666 & 4.7 & 0 \\
\hline 35 & AW17 09 & NBG-17 & -2.375 & -2.232 & 662 & 4.7 & 0 \\
\hline 34 & DW12 01 & PCEA & -3.000 & -2.851 & 658 & 4.6 & 0 \\
\hline 33 & CW11 02 & H-451 & -4.000 & -3.842 & 649 & 4.6 & 0 \\
\hline 32 & AP4 03 & NBG-17 & -5.000 & -4.835 & 641 & 4.6 & 0 \\
\hline 31 & FW03 03 & IG-430 & -6.000 & -5.830 & 632 & 4.5 & 0 \\
\hline 30 & BP5 01 & NBG-18 & -7.000 & -6.825 & 624 & 4.4 & 0 \\
\hline 29 & EW15 09 & IG-110 & -7.625 & -7.446 & 619 & 4.4 & 0 \\
\hline 28 & DA5 01 & PCEA & -8.250 & -8.067 & 615 & 4.3 & 0 \\
\hline 27 & EW03 04 & IG-110 & -9.250 & -9.060 & 609 & 4.3 & 0 \\
\hline 26 & AW10 02 & NBG-17 & -10.250 & -10.054 & 603 & 4.1 & 0 \\
\hline 25 & CW11 03 & H-451 & -11.250 & -11.047 & 599 & 4.0 & 0 \\
\hline 24 & BW12 03 & NBG-18 & -12.250 & -12.041 & 596 & 3.9 & 0 \\
\hline 23 & DW12 02 & PCEA & -13.250 & -13.035 & 593 & 3.7 & 0 \\
\hline 22 & 7D & Flux Monitor & -13.875 & -13.656 & 591 & 3.6 & 0 \\
\hline 21 & EW04 01 & IG-110 & -14.500 & -14.278 & 589 & 3.5 & 0 \\
\hline 20 & AW10 03 & NBG-17 & -15.500 & -15.274 & 585 & 3.3 & 0 \\
\hline 19 & BP5 02 & NBG-18 & -16.500 & -16.270 & 581 & 3.1 & 0 \\
\hline 18 & DA5 02 & PCEA & -17.500 & -17.267 & 575 & 2.9 & 0 \\
\hline 17 & FW03 04 & IG-430 & -18.500 & -18.264 & 567 & 2.7 & 0 \\
\hline 16 & EW15 10 & IG-110 & -19.125 & -18.888 & 560 & 2.6 & 0 \\
\hline 15 & EW04 02 & IG-110 & -19.750 & -19.511 & 552 & 2.4 & 0 \\
\hline 14 & J2 07 & HLM & -20.375 & -20.134 & 542 & 2.2 & 0 \\
\hline 13 & RW2 10 & BAN & -20.625 & -20.383 & 537 & 2.2 & 0 \\
\hline 12 & H571 & A3-3 & -20.875 & -20.631 & 532 & 2.1 & 0 \\
\hline 11 & ТP 19 & 2114 & -21.125 & -20.879 & 526 & 2.0 & 0 \\
\hline 10 & BP7 07 & NBG-18 & -21.375 & -21.128 & 519 & 2.0 & 0 \\
\hline 9 & L2 09 & PPEA & -21.625 & -21.377 & 512 & 1.9 & 0 \\
\hline 8 & K2 10 & PGX & -21.875 & -21.626 & 504 & 1.8 & 0 \\
\hline 7 & P2-09 & PCIB & -22.125 & -21.875 & 496 & 1.8 & 0 \\
\hline 6 & DW18 04 & PCEA & -22.375 & -22.124 & 486 & 1.7 & 0 \\
\hline 5 & M2-08 & NBG-25 & -22.625 & -22.374 & 476 & 1.6 & 0 \\
\hline 4 & S2 08 & NBG-10 & -22.875 & -22.623 & 464 & 1.6 & 0 \\
\hline 3 & FW15 02 & IG-430 & -23.125 & -22.872 & 451 & 1.5 & 0 \\
\hline 2 & EW14 02 & IG-110 & -23.375 & -23.122 & 437 & 1.4 & 0 \\
\hline
\end{tabular}


Table B-5. Stack 3 compressed.

\begin{tabular}{|c|c|c|c|c|c|c|c|}
\hline $\begin{array}{l}\text { Loading } \\
\text { Order }\end{array}$ & $\begin{array}{l}\text { Specimen } \\
\text { ID }\end{array}$ & Graphite Grade & $\begin{array}{l}\text { Nominal } \\
\text { Specimen } \\
\text { Elevation } \\
\text { (in) }\end{array}$ & $\begin{array}{l}\text { End of Test } \\
\text { Specimen } \\
\text { Elevation } \\
\text { (in) }\end{array}$ & $\begin{array}{c}\text { Specimen } \\
\text { Temperature } \\
\left({ }^{\circ} \mathrm{C}\right)\end{array}$ & $\begin{array}{c}\text { Specimen } \\
\text { Dose } \\
\text { (DPA) }\end{array}$ & $\begin{array}{c}\text { Stack Load } \\
\text { (lbf) }\end{array}$ \\
\hline 23 & CW12 02 & $\mathrm{H}-451$ & 19.500 & 18.614 & 542 & 2.0 & 606 \\
\hline 22 & TP 27 & 2114 & 18.875 & 18.004 & 550 & 2.2 & 606 \\
\hline 21 & DW12 03 & PCEA & 18.250 & 17.396 & 557 & 2.3 & 606 \\
\hline 20 & BW13 01 & NBG-18 & 17.250 & 16.425 & 567 & 2.6 & 606 \\
\hline 19 & EW04 03 & IG-110 & 16.250 & 15.454 & 574 & 2.8 & 606 \\
\hline 18 & FW04 01 & IG-430 & 15.250 & 14.485 & 579 & 3.0 & 606 \\
\hline 17 & DW12 04 & PCEA & 14.250 & 13.518 & 584 & 3.2 & 606 \\
\hline 16 & $2 \mathrm{U}$ & Flux Monitor & 13.625 & 12.913 & 587 & 3.3 & 606 \\
\hline 15 & BW13 02 & NBG-18 & 13.000 & 12.306 & 590 & 3.4 & 606 \\
\hline 14 & FW04 02 & IG-430 & 12.000 & 11.338 & 597 & 3.6 & 606 \\
\hline 13 & EW04 04 & IG-110 & 11.000 & 10.373 & 604 & 3.8 & 606 \\
\hline 12 & DW13 01 & PCEA & 10.000 & 9.413 & 613 & 3.9 & 606 \\
\hline 11 & BW13 03 & NBG-18 & 9.000 & 8.451 & 622 & 4.0 & 606 \\
\hline 10 & FW04 04 & IG-430 & 8.000 & 7.487 & 632 & 4.1 & 606 \\
\hline 9 & TP 12 & 2114 & 7.375 & 6.882 & 639 & 4.2 & 606 \\
\hline 8 & CW12 03 & H-451 & 6.750 & 6.281 & 645 & 4.3 & 606 \\
\hline 7 & EW05 01 & IG-110 & 5.750 & 5.323 & 654 & 4.3 & 606 \\
\hline 6 & DW13 02 & PCEA & 4.750 & 4.367 & 662 & 4.4 & 606 \\
\hline 5 & BW14 01 & NBG-18 & 3.750 & 3.409 & 669 & 4.5 & 606 \\
\hline 4 & FW05 01 & IG-430 & 2.750 & 2.446 & 673 & 4.5 & 606 \\
\hline 3 & $8 \mathrm{Y}$ & Flux Monitor & 2.125 & 1.843 & 675 & 4.5 & 606 \\
\hline 2 & AW11 01 & NBG-17 & 1.500 & 1.241 & 675 & 4.6 & 606 \\
\hline
\end{tabular}


Table B-6. Stack 3 uncompressed.

\begin{tabular}{|c|c|c|c|c|c|c|c|}
\hline $\begin{array}{l}\text { Loading } \\
\text { Order }\end{array}$ & $\begin{array}{c}\text { Specimen } \\
\text { ID }\end{array}$ & Graphite Grade & $\begin{array}{l}\text { Nominal } \\
\text { Specimen } \\
\text { Elevation } \\
\text { (in) }\end{array}$ & $\begin{array}{l}\text { End of Test } \\
\text { Specimen } \\
\text { Elevation } \\
\text { (in) }\end{array}$ & $\begin{array}{c}\text { Specimen } \\
\text { Temperature } \\
\left({ }^{\circ} \mathrm{C}\right)\end{array}$ & $\begin{array}{c}\text { Specimen } \\
\text { Dose } \\
\text { (DPA) }\end{array}$ & $\begin{array}{l}\text { Stack Load } \\
\text { (lbf) }\end{array}$ \\
\hline 36 & AW11 02 & NBG-17 & -1.750 & -1.606 & 666 & 4.6 & 0 \\
\hline 35 & TP 24 & 2114 & -2.375 & -2.226 & 662 & 4.6 & 0 \\
\hline 34 & FW05 02 & IG-430 & -3.000 & -2.849 & 657 & 4.6 & 0 \\
\hline 33 & BW14 02 & NBG-18 & -4.000 & -3.844 & 649 & 4.5 & 0 \\
\hline 32 & DW13 03 & PCEA & -5.000 & -4.836 & 641 & 4.5 & 0 \\
\hline 31 & EW05 02 & IG-110 & -6.000 & -5.828 & 632 & 4.4 & 0 \\
\hline 30 & CW13 01 & H-451 & -7.000 & -6.820 & 624 & 4.4 & 0 \\
\hline 29 & TP 25 & 2114 & -7.625 & -7.440 & 619 & 4.3 & 0 \\
\hline 28 & FW05 03 & IG-430 & -8.250 & -8.061 & 614 & 4.3 & 0 \\
\hline 27 & BW14 03 & NBG-18 & -9.250 & -9.056 & 608 & 4.2 & 0 \\
\hline 26 & DW13 04 & PCEA & -10.250 & -10.050 & 603 & 4.1 & 0 \\
\hline 25 & EW05 03 & IG-110 & -11.250 & -11.043 & 598 & 3.9 & 0 \\
\hline 24 & FW05 04 & IG-430 & -12.250 & -12.038 & 595 & 3.8 & 0 \\
\hline 23 & BW15 01 & NBG-18 & -13.250 & -13.034 & 591 & 3.7 & 0 \\
\hline 22 & $1 \mathrm{Y}$ & Flux Monitor & -13.875 & -13.656 & 590 & 3.6 & 0 \\
\hline 21 & DW14 01 & PCEA & -14.500 & -14.278 & 588 & 3.5 & 0 \\
\hline 20 & FW06 01 & IG-430 & -15.500 & -15.274 & 584 & 3.3 & 0 \\
\hline 19 & EW05 04 & IG-110 & -16.500 & -16.270 & 580 & 3.1 & 0 \\
\hline 18 & BW15 02 & NBG-18 & -17.500 & -17.267 & 575 & 2.9 & 0 \\
\hline 17 & DW14 02 & PCEA & -18.500 & -18.264 & 567 & 2.7 & 0 \\
\hline 16 & TP 26 & 2114 & -19.125 & -18.887 & 560 & 2.5 & 0 \\
\hline 15 & CW13 02 & H-451 & -19.750 & -19.511 & 552 & 2.4 & 0 \\
\hline 14 & DW18 05 & PCEA & -20.375 & -20.134 & 542 & 2.2 & 0 \\
\hline 13 & M2-09 & NBG-25 & -20.625 & -20.383 & 537 & 2.1 & 0 \\
\hline 12 & S2 09 & NBG-10 & -20.875 & -20.632 & 532 & 2.1 & 0 \\
\hline 11 & FW15 03 & IG-430 & -21.125 & -20.881 & 526 & 2.0 & 0 \\
\hline 10 & EW14 03 & IG-110 & -21.375 & -21.131 & 519 & 2.0 & 0 \\
\hline 9 & J2 08 & HLM & -21.625 & -21.380 & 512 & 1.9 & 0 \\
\hline 8 & RW4 01 & BAN & -21.875 & -21.629 & 504 & 1.8 & 0 \\
\hline 7 & H572 & A3-3 & -22.125 & -21.878 & 496 & 1.7 & 0 \\
\hline 6 & TP 20 & 2114 & -22.375 & -22.126 & 486 & 1.7 & 0 \\
\hline 5 & L3 04 & PPEA & -22.625 & -22.375 & 476 & 1.6 & 0 \\
\hline 4 & L2 10 & PPEA & -22.875 & -22.625 & 464 & 1.5 & 0 \\
\hline 3 & K3 01 & PGX & -23.125 & -22.874 & 451 & 1.5 & 0 \\
\hline 2 & P2-10 & PCIB & -23.375 & -23.122 & 437 & 1.4 & 0 \\
\hline
\end{tabular}


Table B-7. Stack 4 compressed.

\begin{tabular}{|c|c|c|c|c|c|c|c|}
\hline $\begin{array}{l}\text { Loading } \\
\text { Order }\end{array}$ & $\begin{array}{l}\text { Specimen } \\
\text { ID }\end{array}$ & Graphite Grade & $\begin{array}{l}\text { Nominal } \\
\text { Specimen } \\
\text { Elevation } \\
\text { (in) }\end{array}$ & $\begin{array}{l}\text { End of Test } \\
\text { Specimen } \\
\text { Elevation } \\
\text { (in) }\end{array}$ & $\begin{array}{c}\text { Specimen } \\
\text { Temperature } \\
\left({ }^{\circ} \mathrm{C}\right)\end{array}$ & $\begin{array}{l}\text { Specimen } \\
\text { Dose } \\
\text { (DPA) }\end{array}$ & $\begin{array}{c}\text { Stack Load } \\
\text { (lbf) }\end{array}$ \\
\hline 23 & EW06 01 & IG-110 & 19.500 & 18.799 & 541 & 2.0 & 395 \\
\hline 22 & $\mathrm{AX}$ & Flux Monitor & 18.875 & 18.185 & 549 & 2.1 & 395 \\
\hline 21 & FW06 02 & IG-430 & 18.250 & 17.571 & 556 & 2.3 & 395 \\
\hline 20 & DA5 03 & PCEA & 17.250 & 16.590 & 566 & 2.5 & 395 \\
\hline 19 & BP5 03 & NBG-18 & 16.250 & 15.609 & 573 & 2.7 & 395 \\
\hline 18 & AW11 03 & NBG-17 & 15.250 & 14.629 & 579 & 2.9 & 395 \\
\hline 17 & EW06 02 & IG-110 & 14.250 & 13.651 & 584 & 3.1 & 395 \\
\hline 16 & 18 & Flux Monitor & 13.625 & 13.039 & 587 & 3.3 & 395 \\
\hline 15 & DW14 03 & PCEA & 13.000 & 12.429 & 591 & 3.4 & 395 \\
\hline 14 & BW15 03 & NBG-18 & 12.000 & 11.452 & 597 & 3.5 & 395 \\
\hline 13 & CW13 03 & H-451 & 11.000 & 10.476 & 604 & 3.7 & 395 \\
\hline 12 & AW12 01 & NBG-17 & 10.000 & 9.502 & 613 & 3.8 & 395 \\
\hline 11 & EW06 03 & IG-110 & 9.000 & 8.528 & 623 & 3.9 & 395 \\
\hline 10 & DA6 01 & PCEA & 8.000 & 7.557 & 633 & 4.1 & 395 \\
\hline 9 & $\mathrm{AR}$ & Flux Monitor & 7.375 & 6.949 & 639 & 4.1 & 395 \\
\hline 8 & BP6 01 & NBG-18 & 6.750 & 6.340 & 646 & 4.2 & 395 \\
\hline 7 & FW06 03 & IG-430 & 5.750 & 5.365 & 655 & 4.3 & 395 \\
\hline 6 & AP5 01 & NBG-17 & 4.750 & 4.390 & 664 & 4.3 & 395 \\
\hline 5 & CW2 01 & H-451 & 3.750 & 3.419 & 670 & 4.4 & 395 \\
\hline 4 & DW14 04 & PCEA & 2.750 & 2.450 & 675 & 4.4 & 395 \\
\hline 3 & $3 \mathrm{~F}$ & Flux Monitor & 2.125 & 1.843 & 676 & 4.4 & 395 \\
\hline 2 & BW16 01 & NBG-18 & 1.500 & 1.233 & 677 & 4.5 & 395 \\
\hline
\end{tabular}


Table B-8. Stack 4 uncompressed.

\begin{tabular}{|c|c|c|c|c|c|c|c|}
\hline $\begin{array}{l}\text { Loading } \\
\text { Order }\end{array}$ & $\begin{array}{c}\text { Specimen } \\
\text { ID }\end{array}$ & Graphite Grade & $\begin{array}{l}\text { Nominal } \\
\text { Specimen } \\
\text { Elevation } \\
\text { (in) }\end{array}$ & $\begin{array}{l}\text { End of Test } \\
\text { Specimen } \\
\text { Elevation } \\
\text { (in) }\end{array}$ & $\begin{array}{c}\text { Specimen } \\
\text { Temperature } \\
\left({ }^{\circ} \mathrm{C}\right)\end{array}$ & $\begin{array}{c}\text { Specimen } \\
\text { Dose } \\
\text { (DPA) }\end{array}$ & $\begin{array}{l}\text { Stack Load } \\
\text { (lbf) }\end{array}$ \\
\hline 36 & BW16 02 & NBG-18 & -1.750 & -1.603 & 667 & 4.5 & 0 \\
\hline 35 & $5 B$ & Flux Monitor & -2.375 & -2.224 & 663 & 4.5 & 0 \\
\hline 34 & DW15 02 & PCEA & -3.000 & -2.844 & 658 & 4.5 & 0 \\
\hline 33 & CW2 02 & H-451 & -4.000 & -3.836 & 650 & 4.4 & 0 \\
\hline 32 & AP5 02 & NBG-17 & -5.000 & -4.830 & 641 & 4.4 & 0 \\
\hline 31 & FW06 04 & IG-430 & -6.000 & -5.825 & 632 & 4.3 & 0 \\
\hline 30 & BP6 02 & NBG-18 & -7.000 & -6.820 & 624 & 4.3 & 0 \\
\hline 29 & AL14 03 & NBG-17 & -7.625 & -7.441 & 619 & 4.2 & 0 \\
\hline 28 & DA6 02 & PCEA & -8.250 & -8.061 & 614 & 4.2 & 0 \\
\hline 27 & EW06 04 & IG-110 & -9.250 & -9.055 & 608 & 4.1 & 0 \\
\hline 26 & AW12 02 & NBG-17 & -10.250 & -10.049 & 602 & 4.0 & 0 \\
\hline 25 & CW2 03 & H-451 & -11.250 & -11.043 & 598 & 3.9 & 0 \\
\hline 24 & BW16 03 & NBG-18 & -12.250 & -12.038 & 594 & 3.7 & 0 \\
\hline 23 & DW15 03 & PCEA & -13.250 & -13.033 & 591 & 3.6 & 0 \\
\hline 22 & $2 \mathrm{Y}$ & Flux Monitor & -13.875 & -13.655 & 589 & 3.5 & 0 \\
\hline 21 & EW07 01 & IG-110 & -14.500 & -14.277 & 588 & 3.4 & 0 \\
\hline 20 & AW12 03 & NBG-17 & -15.500 & -15.272 & 584 & 3.2 & 0 \\
\hline 19 & BP6 03 & NBG-18 & -16.500 & -16.269 & 580 & 3.0 & 0 \\
\hline 18 & DA7 01 & PCEA & -17.500 & -17.266 & 575 & 2.8 & 0 \\
\hline 17 & FW07 01 & IG-430 & -18.500 & -18.264 & 567 & 2.6 & 0 \\
\hline 16 & $8 \mathrm{Z}$ & Flux Monitor & -19.125 & -18.888 & 560 & 2.5 & 0 \\
\hline 15 & EW07 02 & IG-110 & -19.750 & -19.512 & 552 & 2.3 & 0 \\
\hline 14 & L3 05 & PPEA & -20.375 & -20.135 & 542 & 2.2 & 0 \\
\hline 13 & L3 01 & PPEA & -20.625 & -20.384 & 537 & 2.1 & 0 \\
\hline 12 & K3 02 & PGX & -20.875 & -20.633 & 532 & 2.0 & 0 \\
\hline 11 & P3-01 & PCIB & -21.125 & -20.882 & 526 & 2.0 & 0 \\
\hline 10 & DW18 06 & PCEA & -21.375 & -21.132 & 519 & 1.9 & 0 \\
\hline 9 & M2-10 & NBG-25 & -21.625 & -21.381 & 512 & 1.9 & 0 \\
\hline 8 & S2 10 & NBG-10 & -21.875 & -21.630 & 504 & 1.8 & 0 \\
\hline 7 & P3-06 & PCIB & -22.125 & -21.879 & 495 & 1.7 & 0 \\
\hline 6 & K3 05 & PGX & -22.375 & -22.128 & 486 & 1.7 & 0 \\
\hline 5 & J2 09 & HLM & -22.625 & -22.377 & 475 & 1.6 & 0 \\
\hline 4 & RW4 02 & BAN & -22.875 & -22.626 & 464 & 1.5 & 0 \\
\hline 3 & H581 & A3-3 & -23.125 & -22.874 & 451 & 1.5 & 0 \\
\hline 2 & TP 21 & 2114 & -23.375 & -23.122 & 437 & 1.4 & 0 \\
\hline
\end{tabular}


Table B-9. Stack 5 compressed.

\begin{tabular}{|c|c|c|c|c|c|c|c|}
\hline $\begin{array}{l}\text { Loading } \\
\text { Order }\end{array}$ & $\begin{array}{l}\text { Specimen } \\
\text { ID }\end{array}$ & Graphite Grade & $\begin{array}{l}\text { Nominal } \\
\text { Specimen } \\
\text { Elevation } \\
\text { (in) }\end{array}$ & $\begin{array}{l}\text { End of Test } \\
\text { Specimen } \\
\text { Elevation } \\
\text { (in) }\end{array}$ & $\begin{array}{c}\text { Specimen } \\
\text { Temperature } \\
\left({ }^{\circ} \mathrm{C}\right)\end{array}$ & $\begin{array}{c}\text { Specimen } \\
\text { Dose } \\
\text { (DPA) }\end{array}$ & $\begin{array}{c}\text { Stack Load } \\
\text { (lbf) }\end{array}$ \\
\hline 23 & CW3 01 & $\mathrm{H}-451$ & 19.500 & 18.545 & 543 & 2.0 & 503 \\
\hline 22 & EW15 11 & IG-110 & 18.875 & 17.936 & 551 & 2.2 & 503 \\
\hline 21 & DW15 04 & PCEA & 18.250 & 17.328 & 558 & 2.3 & 503 \\
\hline 20 & BW2 01 & NBG-18 & 17.250 & 16.355 & 567 & 2.6 & 503 \\
\hline 19 & EW07 03 & IG-110 & 16.250 & 15.385 & 574 & 2.8 & 503 \\
\hline 18 & FW07 03 & IG-430 & 15.250 & 14.415 & 580 & 3.0 & 503 \\
\hline 17 & DW16 01 & PCEA & 14.250 & 13.448 & 585 & 3.2 & 503 \\
\hline 16 & 57 & Flux Monitor & 13.625 & 12.842 & 588 & 3.3 & 503 \\
\hline 15 & BW2 02 & NBG-18 & 13.000 & 12.236 & 591 & 3.5 & 503 \\
\hline 14 & FW07 04 & IG-430 & 12.000 & 11.268 & 597 & 3.6 & 503 \\
\hline 13 & EW07 04 & IG-110 & 11.000 & 10.303 & 605 & 3.8 & 503 \\
\hline 12 & DW16 02 & PCEA & 10.000 & 9.342 & 614 & 3.9 & 503 \\
\hline 11 & BW2 03 & NBG-18 & 9.000 & 8.378 & 624 & 4.1 & 503 \\
\hline 10 & FW08 01 & IG-430 & 8.000 & 7.412 & 634 & 4.2 & 503 \\
\hline 9 & AW17 10 & NBG-17 & 7.375 & 6.807 & 641 & 4.2 & 503 \\
\hline 8 & CW3 02 & H-451 & 6.750 & 6.206 & 647 & 4.3 & 503 \\
\hline 7 & EW08 01 & IG-110 & 5.750 & 5.247 & 657 & 4.4 & 503 \\
\hline 6 & DW16 03 & PCEA & 4.750 & 4.289 & 666 & 4.4 & 503 \\
\hline 5 & BW3 01 & NBG-18 & 3.750 & 3.329 & 673 & 4.5 & 503 \\
\hline 4 & FW08 02 & IG-430 & 2.750 & 2.365 & 677 & 4.5 & 503 \\
\hline 3 & $\mathrm{AL}$ & Flux Monitor & 2.125 & 1.761 & 679 & 4.6 & 503 \\
\hline 2 & AW13 01 & NBG-17 & 1.500 & 1.159 & 680 & 4.6 & 503 \\
\hline
\end{tabular}


Table B-10. Stack 5 uncompressed.

\begin{tabular}{|c|c|c|c|c|c|c|c|}
\hline $\begin{array}{l}\text { Loading } \\
\text { Order }\end{array}$ & $\begin{array}{c}\text { Specimen } \\
\text { ID }\end{array}$ & Graphite Grade & $\begin{array}{l}\text { Nominal } \\
\text { Specimen } \\
\text { Elevation } \\
\text { (in) }\end{array}$ & $\begin{array}{l}\text { End of Test } \\
\text { Specimen } \\
\text { Elevation } \\
\text { (in) }\end{array}$ & $\begin{array}{c}\text { Specimen } \\
\text { Temperature } \\
\left({ }^{\circ} \mathrm{C}\right)\end{array}$ & $\begin{array}{c}\text { Specimen } \\
\text { Dose } \\
\text { (DPA) }\end{array}$ & $\begin{array}{l}\text { Stack Load } \\
\text { (lbf) }\end{array}$ \\
\hline 36 & AW13 02 & NBG-17 & -1.750 & -1.592 & 671 & 4.6 & 0 \\
\hline 35 & EW15 08 & IG-110 & -2.375 & -2.213 & 667 & 4.6 & 0 \\
\hline 34 & FW08 03 & IG-430 & -3.000 & -2.836 & 662 & 4.6 & 0 \\
\hline 33 & BW3 02 & NBG-18 & -4.000 & -3.832 & 653 & 4.5 & 0 \\
\hline 32 & DW16 04 & PCEA & -5.000 & -4.825 & 644 & 4.5 & 0 \\
\hline 31 & EW08 02 & IG-110 & -6.000 & -5.818 & 635 & 4.4 & 0 \\
\hline 30 & CW3 03 & H-451 & -7.000 & -6.811 & 626 & 4.4 & 0 \\
\hline 29 & EW15 07 & IG-110 & -7.625 & -7.432 & 621 & 4.3 & 0 \\
\hline 28 & FW08 04 & IG-430 & -8.250 & -8.055 & 617 & 4.3 & 0 \\
\hline 27 & BW3 03 & NBG-18 & -9.250 & -9.050 & 610 & 4.2 & 0 \\
\hline 26 & DW17 01 & PCEA & -10.250 & -10.045 & 604 & 4.1 & 0 \\
\hline 25 & EW08 03 & IG-110 & -11.250 & -11.039 & 599 & 4.0 & 0 \\
\hline 24 & FW09 01 & IG-430 & -12.250 & -12.035 & 596 & 3.8 & 0 \\
\hline 23 & BW4 01 & NBG-18 & -13.250 & -13.031 & 593 & 3.7 & 0 \\
\hline 22 & $7 \mathrm{Z}$ & Flux Monitor & -13.875 & -13.654 & 591 & 3.6 & 0 \\
\hline 21 & DW17 02 & PCEA & -14.500 & -14.277 & 589 & 3.5 & 0 \\
\hline 20 & FW09 02 & IG-430 & -15.500 & -15.274 & 585 & 3.3 & 0 \\
\hline 19 & EW08 04 & IG-110 & -16.500 & -16.270 & 581 & 3.1 & 0 \\
\hline 18 & BW4 02 & NBG-18 & -17.500 & -17.267 & 575 & 2.9 & 0 \\
\hline 17 & DW17 04 & PCEA & -18.500 & -18.265 & 567 & 2.7 & 0 \\
\hline 16 & EW15 06 & IG-110 & -19.125 & -18.888 & 561 & 2.5 & 0 \\
\hline 15 & CW4 01 & H-451 & -19.750 & -19.512 & 552 & 2.4 & 0 \\
\hline 14 & J2 10 & HLM & -20.375 & -20.135 & 542 & 2.2 & 0 \\
\hline 13 & RW4 03 & BAN & -20.625 & -20.384 & 537 & 2.2 & 0 \\
\hline 12 & H582 & A3-3 & -20.875 & -20.631 & 532 & 2.1 & 0 \\
\hline 11 & TP 22 & 2114 & -21.125 & -20.880 & 526 & 2.0 & 0 \\
\hline 10 & L3 06 & PPEA & -21.375 & -21.129 & 519 & 2.0 & 0 \\
\hline 9 & L3 02 & PPEA & -21.625 & -21.378 & 512 & 1.9 & 0 \\
\hline 8 & K3 03 & PGX & -21.875 & -21.627 & 504 & 1.8 & 0 \\
\hline 7 & P3-02 & PCIB & -22.125 & -21.876 & 496 & 1.8 & 0 \\
\hline 6 & DW18 07 & PCEA & -22.375 & -22.125 & 486 & 1.7 & 0 \\
\hline 5 & M2-11 & NBG-25 & -22.625 & -22.374 & 476 & 1.6 & 0 \\
\hline 4 & S2 11 & NBG-10 & -22.875 & -22.624 & 464 & 1.5 & 0 \\
\hline 3 & P3-05 & PCIB & -23.125 & -22.873 & 451 & 1.5 & 0 \\
\hline 2 & EW14 05 & IG-110 & -23.375 & -23.122 & 437 & 1.4 & 0 \\
\hline
\end{tabular}


Table B-11. Stack 6 compressed.

\begin{tabular}{|c|c|c|c|c|c|c|c|}
\hline $\begin{array}{l}\text { Loading } \\
\text { Order }\end{array}$ & $\begin{array}{l}\text { Specimen } \\
\text { ID }\end{array}$ & Graphite Grade & $\begin{array}{l}\text { Nominal } \\
\text { Specimen } \\
\text { Elevation } \\
\text { (in) }\end{array}$ & $\begin{array}{l}\text { End of Test } \\
\text { Specimen } \\
\text { Elevation } \\
\text { (in) }\end{array}$ & $\begin{array}{c}\text { Specimen } \\
\text { Temperature } \\
\left({ }^{\circ} \mathrm{C}\right)\end{array}$ & $\begin{array}{c}\text { Specimen } \\
\text { Dose } \\
\text { (DPA) }\end{array}$ & $\begin{array}{c}\text { Stack Load } \\
\text { (lbf) }\end{array}$ \\
\hline 23 & EW09 01 & IG-110 & 19.500 & 18.608 & 543 & 2.1 & 604 \\
\hline 22 & TP 16 & 2114 & 18.875 & 17.999 & 551 & 2.2 & 604 \\
\hline 21 & FW09 03 & IG-430 & 18.250 & 17.390 & 558 & 2.4 & 604 \\
\hline 20 & DA3 03 & PCEA & 17.250 & 16.418 & 567 & 2.6 & 604 \\
\hline 19 & BP4 01 & NBG-18 & 16.250 & 15.446 & 575 & 2.8 & 604 \\
\hline 18 & AW13 03 & NBG-17 & 15.250 & 14.474 & 580 & 3.0 & 604 \\
\hline 17 & EW09 02 & IG-110 & 14.250 & 13.507 & 585 & 3.3 & 604 \\
\hline 16 & $5 \mathrm{~F}$ & Flux Monitor & 13.625 & 12.902 & 588 & 3.4 & 604 \\
\hline 15 & DW2 01 & PCEA & 13.000 & 12.298 & 591 & 3.5 & 604 \\
\hline 14 & BW4 03 & NBG-18 & 12.000 & 11.332 & 597 & 3.7 & 604 \\
\hline 13 & CW4 02 & H-451 & 11.000 & 10.368 & 604 & 3.8 & 604 \\
\hline 12 & AW14 01 & NBG-17 & 10.000 & 9.405 & 613 & 4.0 & 604 \\
\hline 11 & EA9 02 & IG-110 & 9.000 & 8.443 & 623 & 4.1 & 604 \\
\hline 10 & DA3 02 & PCEA & 8.000 & 7.486 & 634 & 4.2 & 604 \\
\hline 9 & TP 17 & 2114 & 7.375 & 6.887 & 640 & 4.3 & 604 \\
\hline 8 & BP3 03 & NBG-18 & 6.750 & 6.283 & 647 & 4.3 & 604 \\
\hline 7 & FW09 04 & IG-430 & 5.750 & 5.320 & 657 & 4.4 & 604 \\
\hline 6 & AP5 03 & NBG-17 & 4.750 & 4.357 & 666 & 4.5 & 604 \\
\hline 5 & CW4 03 & H-451 & 3.750 & 3.397 & 673 & 4.6 & 604 \\
\hline 4 & DW2 02 & PCEA & 2.750 & 2.442 & 678 & 4.6 & 604 \\
\hline 3 & $5 \mathrm{H}$ & Flux Monitor & 2.125 & 1.844 & 680 & 4.6 & 604 \\
\hline 2 & BW5 01 & NBG-18 & 1.500 & 1.241 & 681 & 4.6 & 604 \\
\hline
\end{tabular}


Table B-12. Stack 6 uncompressed.

\begin{tabular}{|c|c|c|c|c|c|c|c|}
\hline $\begin{array}{l}\text { Loading } \\
\text { Order }\end{array}$ & $\begin{array}{c}\text { Specimen } \\
\text { ID }\end{array}$ & Graphite Grade & $\begin{array}{l}\text { Nominal } \\
\text { Specimen } \\
\text { Elevation } \\
\text { (in) }\end{array}$ & $\begin{array}{l}\text { End of Test } \\
\text { Specimen } \\
\text { Elevation } \\
\text { (in) }\end{array}$ & $\begin{array}{c}\text { Specimen } \\
\text { Temperature } \\
\left({ }^{\circ} \mathrm{C}\right)\end{array}$ & $\begin{array}{c}\text { Specimen } \\
\text { Dose } \\
\text { (DPA) }\end{array}$ & $\begin{array}{l}\text { Stack Load } \\
\text { (lbf) }\end{array}$ \\
\hline 36 & BW5 02 & NBG-18 & -1.750 & -1.598 & 672 & 4.7 & 0 \\
\hline 35 & ТP 13 & 2114 & -2.375 & -2.220 & 668 & 4.7 & 0 \\
\hline 34 & DW2 03 & PCEA & -3.000 & -2.840 & 663 & 4.6 & 0 \\
\hline 33 & CW5 01 & H-451 & -4.000 & -3.832 & 655 & 4.6 & 0 \\
\hline 32 & AP6 01 & NBG-17 & -5.000 & -4.826 & 646 & 4.6 & 0 \\
\hline 31 & FW10 01 & IG-430 & -6.000 & -5.823 & 637 & 4.5 & 0 \\
\hline 30 & BP3 02 & NBG-18 & -7.000 & -6.819 & 628 & 4.4 & 0 \\
\hline 29 & TP 14 & 2114 & -7.625 & -7.440 & 623 & 4.4 & 0 \\
\hline 28 & DA2 03 & PCEA & -8.250 & -8.061 & 619 & 4.3 & 0 \\
\hline 27 & EW09 04 & IG-110 & -9.250 & -9.055 & 612 & 4.3 & 0 \\
\hline 26 & AW14 02 & NBG-17 & -10.250 & -10.050 & 607 & 4.1 & 0 \\
\hline 25 & CW5 03 & H-451 & -11.250 & -11.043 & 603 & 4.0 & 0 \\
\hline 24 & BW5 03 & NBG-18 & -12.250 & -12.037 & 599 & 3.9 & 0 \\
\hline 23 & DW2 04 & PCEA & -13.250 & -13.032 & 596 & 3.7 & 0 \\
\hline 22 & $7 \mathrm{Y}$ & Flux Monitor & -13.875 & -13.653 & 594 & 3.6 & 0 \\
\hline 21 & EW10 01 & IG-110 & -14.500 & -14.275 & 591 & 3.5 & 0 \\
\hline 20 & AW14 03 & NBG-17 & -15.500 & -15.270 & 588 & 3.4 & 0 \\
\hline 19 & BP3 01 & NBG-18 & -16.500 & -16.267 & 583 & 3.2 & 0 \\
\hline 18 & DA2 02 & PCEA & -17.500 & -17.263 & 577 & 2.9 & 0 \\
\hline 17 & FW10 02 & IG-430 & -18.500 & -18.261 & 568 & 2.7 & 0 \\
\hline 16 & TP 15 & 2114 & -19.125 & -18.885 & 561 & 2.6 & 0 \\
\hline 15 & EW10 02 & IG-110 & -19.750 & -19.509 & 553 & 2.4 & 0 \\
\hline 14 & CW14 06 & $\mathrm{H}-451$ & -20.375 & -20.132 & 542 & 2.2 & 0 \\
\hline 13 & M2-12 & NBG-25 & -20.625 & -20.381 & 537 & 2.2 & 0 \\
\hline 12 & S2 12 & NBG-10 & -20.875 & -20.630 & 532 & 2.1 & 0 \\
\hline 11 & K3 06 & PGX & -21.125 & -20.879 & 526 & 2.0 & 0 \\
\hline 10 & EW14 06 & IG-110 & -21.375 & -21.129 & 519 & 2.0 & 0 \\
\hline 9 & J2 11 & HLM & -21.625 & -21.378 & 512 & 1.9 & 0 \\
\hline 8 & RW4 04 & BAN & -21.875 & -21.627 & 504 & 1.8 & 0 \\
\hline 7 & H591 & A3-3 & -22.125 & -21.876 & 496 & 1.8 & 0 \\
\hline 6 & TP 23 & 2114 & -22.375 & -22.124 & 486 & 1.7 & 0 \\
\hline 5 & P3-04 & PCIB & -22.625 & -22.373 & 476 & 1.6 & 0 \\
\hline 4 & L3 03 & PPEA & -22.875 & -22.623 & 464 & 1.6 & 0 \\
\hline 3 & K3 04 & PGX & -23.125 & -22.873 & 451 & 1.5 & 0 \\
\hline 2 & P3-03 & PCIB & -23.375 & -23.122 & 437 & 1.4 & 0 \\
\hline
\end{tabular}


Table B-13. Stack 7 uncompressed (1 of 6).

\begin{tabular}{|c|c|c|c|c|c|c|}
\hline $\begin{array}{c}\text { Loading } \\
\text { Order }\end{array}$ & $\begin{array}{c}\text { Spe cimen } \\
\text { ID } \\
\end{array}$ & Graphite Grade & $\begin{array}{l}\text { Nominal } \\
\text { Spe cimen } \\
\text { Ele vation } \\
\text { (in) }\end{array}$ & $\begin{array}{c}\text { End of Test } \\
\text { Specimen } \\
\text { Ele vation (in) }\end{array}$ & $\begin{array}{c}\text { Specimen } \\
\text { Te mpe rature } \\
\left({ }^{\circ} \mathrm{C}\right)\end{array}$ & $\begin{array}{c}\text { Specimen } \\
\text { Dose (DPA) }\end{array}$ \\
\hline 170 & A3-P43-Z12 & A3-27 & 18.375 & 18.383 & 624 & 2.2 \\
\hline 169 & J1 11 & HLM & 18.125 & 18.134 & 614 & 2.3 \\
\hline 168 & K2 02 & PGX & 17.875 & 17.886 & 607 & 2.3 \\
\hline 167 & L2 01 & PPEA & 17.625 & 17.637 & 601 & 2.4 \\
\hline 166 & M1-12 & NBG-25 & 17.375 & 17.388 & 597 & 2.4 \\
\hline 165 & TP 11 & 2114 & 17.125 & 17.139 & 593 & 2.5 \\
\hline 164 & P2-01 & PCIB & 16.875 & 16.890 & 591 & 2.6 \\
\hline 163 & RW2 02 & BAN & 16.625 & 16.641 & 590 & 2.6 \\
\hline 162 & S1 11 & NBG-10 & 16.375 & 16.392 & 589 & 2.7 \\
\hline 161 & CPB101 & HOPG CAN & 16.125 & 16.143 & 590 & 2.7 \\
\hline 160 & BP7 08 & NBG-18 & 15.875 & 15.894 & 590 & 2.8 \\
\hline 159 & DW18 08 & PCEA & 15.625 & 15.645 & 591 & 2.8 \\
\hline 158 & BP7 09 & NBG-18 & 15.375 & 15.396 & 592 & 2.9 \\
\hline 157 & FW15 04 & IG-430 & 15.125 & 15.147 & 594 & 3.0 \\
\hline 156 & EW14 04 & IG-110 & 14.875 & 14.898 & 596 & 3.0 \\
\hline 155 & CW14 05 & $\mathrm{H}-451$ & 14.625 & 14.649 & 598 & 3.1 \\
\hline 154 & A3-H08-Z19 & A3-27 & 14.375 & 14.401 & 600 & 3.1 \\
\hline 153 & J1 10 & HLM & 14.125 & 14.154 & 602 & 3.2 \\
\hline 152 & K2 01 & PGX & 13.875 & 13.905 & 604 & 3.2 \\
\hline 151 & L1 10 & PPEA & 13.625 & 13.657 & 606 & 3.3 \\
\hline 150 & M1-11 & NBG-25 & 13.375 & 13.408 & 609 & 3.3 \\
\hline 149 & TP 10 & 2114 & 13.125 & 13.160 & 611 & 3.4 \\
\hline 148 & P1-10 & PCIB & 12.875 & 12.910 & 613 & 3.4 \\
\hline 147 & RW2 01 & BAN & 12.625 & 12.661 & 615 & 3.5 \\
\hline 146 & S1 10 & NBG-10 & 12.375 & 12.412 & 618 & 3.5 \\
\hline 145 & СРB91 & HOPG CAN & 12.125 & 12.164 & 620 & 3.5 \\
\hline 144 & BP7 10 & NBG-18 & 11.875 & 11.915 & 622 & 3.6 \\
\hline 143 & DA8 05 & PCEA & 11.625 & 11.667 & 624 & 3.6 \\
\hline 142 & AP7 08 & NBG-17 & 11.375 & 11.418 & 627 & 3.7 \\
\hline 141 & FW15 05 & IG-430 & 11.125 & 11.169 & 629 & 3.7 \\
\hline
\end{tabular}


Table B-14. Stack 7 uncompressed (2 of 6).

\begin{tabular}{|c|c|c|c|c|c|c|}
\hline $\begin{array}{l}\text { Loading } \\
\text { Order }\end{array}$ & $\begin{array}{c}\text { Spe cimen } \\
\text { ID }\end{array}$ & Graphite Grade & $\begin{array}{l}\text { Nominal } \\
\text { Spe cimen } \\
\text { Elevation } \\
\text { (in) }\end{array}$ & $\begin{array}{c}\text { End of Test } \\
\text { Specimen } \\
\text { Elevation (in) }\end{array}$ & $\begin{array}{c}\text { Spe cime } n \\
\text { Te mpe rature } \\
\left({ }^{\circ} \mathrm{C}\right)\end{array}$ & $\begin{array}{c}\text { Specimen } \\
\text { Dose (DPA) }\end{array}$ \\
\hline 140 & EW15 03 & IG-110 & 10.875 & 10.920 & 631 & 3.7 \\
\hline 139 & CW14 04 & H-451 & 10.625 & 10.672 & 634 & 3.8 \\
\hline 138 & H521 & A3-3 & 10.375 & 10.424 & 636 & 3.8 \\
\hline 137 & J1 09 & HLM & 10.125 & 10.176 & 638 & 3.9 \\
\hline 136 & K1 10 & PGX & 9.875 & 9.928 & 641 & 3.9 \\
\hline 135 & L1 09 & PPEA & 9.625 & 9.680 & 643 & 3.9 \\
\hline 134 & M1-10 & NBG-25 & 9.375 & 9.432 & 645 & 4.0 \\
\hline 133 & ТР 09 & 2114 & 9.125 & 9.184 & 648 & 4.0 \\
\hline 132 & P1-09 & PCIB & 8.875 & 8.935 & 650 & 4.0 \\
\hline 131 & RW1 10 & BAN & 8.625 & 8.686 & 653 & 4.1 \\
\hline 130 & S1 09 & NBG-10 & 8.375 & 8.438 & 655 & 4.1 \\
\hline 129 & CPB81 & HOPG CAN & 8.125 & 8.190 & 658 & 4.1 \\
\hline 128 & BW17 01 & NBG-18 & 7.875 & 7.941 & 660 & 4.2 \\
\hline 127 & DA8 04 & PCEA & 7.625 & 7.693 & 663 & 4.2 \\
\hline 126 & AP7 09 & NBG-17 & 7.375 & 7.444 & 665 & 4.2 \\
\hline 125 & FW15 06 & IG-430 & 7.125 & 7.196 & 668 & 4.2 \\
\hline 124 & EW15 02 & IG-110 & 6.875 & 6.947 & 670 & 4.3 \\
\hline 123 & CW14 03 & H-451 & 6.625 & 6.698 & 673 & 4.3 \\
\hline 122 & H512 & A3-3 & 6.375 & 6.449 & 675 & 4.3 \\
\hline 121 & $\mathrm{~J} 108$ & HLM & 6.125 & 6.201 & 677 & 4.3 \\
\hline 120 & K1 09 & PGX & 5.875 & 5.953 & 680 & 4.3 \\
\hline 119 & L1 08 & PPEA & 5.625 & 5.704 & 682 & 4.4 \\
\hline 118 & M1-09 & NBG-25 & 5.375 & 5.456 & 684 & 4.4 \\
\hline 117 & ТP 08 & 2114 & 5.125 & 5.207 & 687 & 4.4 \\
\hline 116 & P1-08 & PCIB & 4.875 & 4.958 & 689 & 4.4 \\
\hline 115 & RW1 09 & BAN & 4.625 & 4.709 & 691 & 4.4 \\
\hline 114 & S1 08 & NBG-10 & 4.375 & 4.461 & 693 & 4.5 \\
\hline 113 & CPB71 & HOPG CAN & 4.125 & 4.212 & 695 & 4.5 \\
\hline 112 & BW17 09 & NBG-18 & 3.875 & 3.964 & 696 & 4.5 \\
\hline 111 & DA8 03 & PCEA & 3.625 & 3.715 & 698 & 4.5 \\
\hline
\end{tabular}


Table B-15. Stack 7 uncompressed (3 of 6).

\begin{tabular}{|c|c|c|c|c|c|c|}
\hline $\begin{array}{c}\text { Loading } \\
\text { Order }\end{array}$ & $\begin{array}{c}\text { Spe cime n } \\
\text { ID }\end{array}$ & Graphite Grade & $\begin{array}{l}\text { Nominal } \\
\text { Spe cimen } \\
\text { Ele vation } \\
\text { (in) }\end{array}$ & $\begin{array}{c}\text { End of Test } \\
\text { Specimen } \\
\text { Ele vation (in) }\end{array}$ & $\begin{array}{c}\text { Specimen } \\
\text { Te mpe rature } \\
\left({ }^{\circ} \mathrm{C}\right)\end{array}$ & $\begin{array}{c}\text { Specimen } \\
\text { Dose (DPA) }\end{array}$ \\
\hline 110 & AP7 10 & NBG-17 & 3.375 & 3.467 & 700 & 4.5 \\
\hline 109 & FW16 01 & IG-430 & 3.125 & 3.218 & 701 & 4.5 \\
\hline 108 & EW15 01 & IG-110 & 2.875 & 2.969 & 702 & 4.5 \\
\hline 107 & CPB151 & HOPG CAN & 2.625 & 2.720 & 703 & 4.6 \\
\hline 106 & A3-P33-Z09 & A3-27 & 2.375 & 2.469 & 704 & 4.6 \\
\hline 105 & J1 07 & HLM & 2.125 & 2.218 & 705 & 4.6 \\
\hline 104 & K1 08 & PGX & 1.875 & 1.971 & 706 & 4.6 \\
\hline 103 & L1 07 & PPEA & 1.625 & 1.723 & 707 & 4.6 \\
\hline 102 & M1-08 & NBG-25 & 1.375 & 1.474 & 707 & 4.6 \\
\hline 101 & TP 07 & 2114 & 1.125 & 1.226 & 707 & 4.6 \\
\hline 100 & P1-07 & PCIB & 0.875 & 0.977 & 707 & 4.6 \\
\hline 99 & RW1 08 & BAN & 0.625 & 0.728 & 707 & 4.6 \\
\hline 98 & S1 07 & NBG-10 & 0.375 & 0.479 & 707 & 4.6 \\
\hline 97 & CPB61 & HOPG CAN & 0.125 & 0.231 & 707 & 4.6 \\
\hline 96 & BW17 08 & NBG-18 & -0.125 & -0.017 & 706 & 4.6 \\
\hline 95 & DA8 02 & PCEA & -0.375 & -0.266 & 705 & 4.6 \\
\hline 94 & AW17 01 & NBG-17 & -0.625 & -0.513 & 704 & 4.6 \\
\hline 93 & FW15 12 & IG-430 & -0.875 & -0.761 & 703 & 4.6 \\
\hline 92 & EW14 12 & IG-110 & -1.125 & -1.010 & 702 & 4.6 \\
\hline 91 & CPB141 & HOPG CAN & -1.375 & -1.259 & 701 & 4.6 \\
\hline 90 & A3-H08-Z07 & A3-27 & -1.625 & -1.509 & 700 & 4.6 \\
\hline 89 & J106 & HLM & -1.875 & -1.759 & 698 & 4.6 \\
\hline 88 & K1 07 & PGX & -2.125 & -2.006 & 697 & 4.6 \\
\hline 87 & L1 06 & PPEA & -2.375 & -2.253 & 695 & 4.6 \\
\hline 86 & M1-07 & NBG-25 & -2.625 & -2.501 & 693 & 4.6 \\
\hline 85 & TP 06 & 2114 & -2.875 & -2.750 & 691 & 4.6 \\
\hline 84 & P1-06 & PCIB & -3.125 & -2.998 & 689 & 4.6 \\
\hline 83 & RW1 07 & BAN & -3.375 & -3.246 & 687 & 4.6 \\
\hline 82 & S1 06 & NBG-10 & -3.625 & -3.495 & 685 & 4.6 \\
\hline 81 & CPB51 & HOPG CAN & -3.875 & -3.743 & 683 & 4.6 \\
\hline
\end{tabular}


Table B-16. Stack 7 uncompressed (4 of 6).

\begin{tabular}{|c|c|c|c|c|c|c|}
\hline $\begin{array}{c}\text { Loading } \\
\text { Order }\end{array}$ & $\begin{array}{c}\text { Specimen } \\
\text { ID }\end{array}$ & Graphite Grade & $\begin{array}{l}\text { Nominal } \\
\text { Specimen } \\
\text { Ele vation } \\
\text { (in) }\end{array}$ & $\begin{array}{c}\text { End of Test } \\
\text { Specimen } \\
\text { Elevation (in) }\end{array}$ & $\begin{array}{c}\text { Specimen } \\
\text { Tempe rature } \\
\left({ }^{\circ} \mathrm{C}\right)\end{array}$ & $\begin{array}{c}\text { Specimen } \\
\text { Dose (DPA) }\end{array}$ \\
\hline 80 & BW17 07 & NBG-18 & -4.125 & -3.991 & 681 & 4.6 \\
\hline 79 & DA8 01 & PCEA & -4.375 & -4.239 & 678 & 4.6 \\
\hline 78 & AW17 02 & NBG-17 & -4.625 & -4.488 & 676 & 4.5 \\
\hline 77 & FW15 11 & IG-430 & -4.875 & -4.736 & 674 & 4.5 \\
\hline 76 & EW14 11 & IG-110 & -5.125 & -4.985 & 671 & 4.5 \\
\hline 75 & CPB131 & HOPG CAN & -5.375 & -5.233 & 669 & 4.5 \\
\hline 74 & A3-P43-Z03 & A3-27 & -5.625 & -5.483 & 667 & 4.5 \\
\hline 73 & $\mathrm{~J} 105$ & HLM & -5.875 & -5.731 & 664 & 4.5 \\
\hline 72 & K1 06 & PGX & -6.125 & -5.979 & 662 & 4.5 \\
\hline 71 & L1 05 & PPEA & -6.375 & -6.226 & 660 & 4.4 \\
\hline 70 & M1-06 & NBG-25 & -6.625 & -6.474 & 658 & 4.4 \\
\hline 69 & TP 05 & 2114 & -6.875 & -6.722 & 655 & 4.4 \\
\hline 68 & P1-05 & PCIB & -7.125 & -6.970 & 653 & 4.4 \\
\hline 67 & RW1 06 & BAN & -7.375 & -7.218 & 651 & 4.4 \\
\hline 66 & S1 05 & NBG-10 & -7.625 & -7.466 & 649 & 4.4 \\
\hline 65 & CPB41 & HOPG CAN & -7.875 & -7.714 & 647 & 4.3 \\
\hline 64 & BW17 05 & NBG-18 & -8.125 & -7.963 & 645 & 4.3 \\
\hline 63 & DW18 12 & PCEA & -8.375 & -8.211 & 643 & 4.3 \\
\hline 62 & AW17 03 & NBG-17 & -8.625 & -8.458 & 641 & 4.3 \\
\hline 61 & FW15 10 & IG-430 & -8.875 & -8.706 & 640 & 4.2 \\
\hline 60 & EW14 10 & IG-110 & -9.125 & -8.955 & 638 & 4.2 \\
\hline 59 & CPB121 & HOPG CAN & -9.375 & -9.204 & 636 & 4.2 \\
\hline 58 & H491 & A3-3 & -9.625 & -9.453 & 635 & 4.2 \\
\hline 57 & $\mathrm{~J} 104$ & HLM & -9.875 & -9.701 & 633 & 4.1 \\
\hline 56 & K1 05 & PGX & -10.125 & -9.948 & 632 & 4.1 \\
\hline 55 & L1 04 & PPEA & -10.375 & -10.195 & 630 & 4.1 \\
\hline 54 & M1-05 & NBG-25 & -10.625 & -10.443 & 629 & 4.1 \\
\hline 53 & TP 04 & 2114 & -10.875 & -10.691 & 628 & 4.0 \\
\hline 52 & P1-04 & PCIB & -11.125 & -10.939 & 627 & 4.0 \\
\hline 51 & RW1 05 & BAN & -11.375 & -11.188 & 625 & 4.0 \\
\hline
\end{tabular}


Table B-17. Stack 7 uncompressed (5 of 6).

\begin{tabular}{|c|c|c|c|c|c|c|}
\hline $\begin{array}{c}\text { Loading } \\
\text { Order }\end{array}$ & $\begin{array}{c}\text { Specimen } \\
\text { ID }\end{array}$ & Graphite Grade & $\begin{array}{l}\text { Nominal } \\
\text { Specimen } \\
\text { Ele vation } \\
\text { (in) }\end{array}$ & $\begin{array}{c}\text { End of Test } \\
\text { Specimen } \\
\text { Ele vation (in) }\end{array}$ & $\begin{array}{c}\text { Spe cimen } \\
\text { Te mpe rature } \\
\left({ }^{\circ} \mathrm{C}\right)\end{array}$ & $\begin{array}{c}\text { Specimen } \\
\text { Dose (DPA) }\end{array}$ \\
\hline 50 & S1 04 & NBG-10 & -11.625 & -11.435 & 624 & 3.9 \\
\hline 49 & CPB31 & HOPG CAN & -11.875 & -11.684 & 623 & 3.9 \\
\hline 48 & BW17 04 & NBG-18 & -12.125 & -11.933 & 622 & 3.9 \\
\hline 47 & DW18 11 & PCEA & -12.375 & -12.181 & 621 & 3.8 \\
\hline 46 & AW17 06 & NBG-17 & -12.625 & -12.429 & 620 & 3.8 \\
\hline 45 & FW15 09 & IG-430 & -12.875 & -12.677 & 619 & 3.8 \\
\hline 44 & EW14 09 & IG-110 & -13.125 & -12.926 & 618 & 3.7 \\
\hline 43 & СРB111 & HOPG CAN & -13.375 & -13.175 & 617 & 3.7 \\
\hline 42 & H482 & A3-3 & -13.625 & -13.423 & 616 & 3.6 \\
\hline 41 & $\mathrm{~J} 103$ & HLM & -13.875 & -13.671 & 615 & 3.6 \\
\hline 40 & K1 04 & PGX & -14.125 & -13.918 & 614 & 3.6 \\
\hline 39 & L1 03 & PPEA & -14.375 & -14.166 & 612 & 3.5 \\
\hline 38 & M1-04 & NBG-25 & -14.625 & -14.414 & 611 & 3.5 \\
\hline 37 & TP 03 & 2114 & -14.875 & -14.663 & 610 & 3.4 \\
\hline 36 & P1-03 & PCIB & -15.125 & -14.911 & 609 & 3.4 \\
\hline 35 & RW1 04 & BAN & -15.375 & -15.160 & 607 & 3.3 \\
\hline 34 & S1 03 & NBG-10 & -15.625 & -15.409 & 606 & 3.3 \\
\hline 33 & CPB21 & HOPG CAN & -15.875 & -15.658 & 605 & 3.2 \\
\hline 32 & BW17 03 & NBG-18 & -16.125 & -15.907 & 603 & 3.2 \\
\hline 31 & DW18 10 & PCEA & -16.375 & -16.156 & 601 & 3.1 \\
\hline 30 & AW17 05 & NBG-17 & -16.625 & -16.404 & 600 & 3.1 \\
\hline 29 & FW1508 & IG-430 & -16.875 & -16.653 & 598 & 3.0 \\
\hline 28 & EW14 08 & IG-110 & -17.125 & -16.902 & 596 & 3.0 \\
\hline 27 & CA11 02 & $\mathrm{H}-451$ & -17.375 & -17.151 & 594 & 2.9 \\
\hline 26 & A3-P33-Z20 & A3-27 & -17.625 & -17.400 & 592 & 2.9 \\
\hline 25 & $\mathrm{~J} 102$ & HLM & -17.875 & -17.648 & 589 & 2.8 \\
\hline 24 & K1 03 & PGX & -18.125 & -17.896 & 587 & 2.8 \\
\hline 23 & L1 02 & PPEA & -18.375 & -18.144 & 584 & 2.7 \\
\hline 22 & M1-02 & NBG-25 & -18.625 & -18.393 & 581 & 2.7 \\
\hline 21 & TP 02 & 2114 & -18.875 & -18.642 & 578 & 2.6 \\
\hline
\end{tabular}


Table B-18. Stack 7 uncompressed (6 of 6).

\begin{tabular}{|c|c|c|c|c|c|c|}
\hline $\begin{array}{c}\text { Loading } \\
\text { Order }\end{array}$ & $\begin{array}{c}\text { Specimen } \\
\text { ID }\end{array}$ & Graphite Grade & $\begin{array}{c}\text { Nominal } \\
\text { Specimen } \\
\text { Ele vation }\end{array}$ & $\begin{array}{c}\text { End of Test } \\
\text { Specimen } \\
\text { Ele vation (in) }\end{array}$ & $\begin{array}{c}\text { Specimen } \\
\text { Temperature } \\
\left({ }^{\circ} \text { C) }\right.\end{array}$ & $\begin{array}{c}\text { Specimen } \\
\text { Dose (DPA) }\end{array}$ \\
\hline 20 & P1-02 & PCIB & -19.125 & -18.891 & 575 & 2.5 \\
\hline 19 & RW1 03 & BAN & -19.375 & -19.140 & 571 & 2.5 \\
\hline 18 & S1 02 & NBG-10 & -19.625 & -19.390 & 567 & 2.4 \\
\hline 17 & CPB11 & HOPG CAN & -19.875 & -19.639 & 563 & 2.4 \\
\hline 16 & BW17 02 & NBG-18 & -20.125 & -19.888 & 558 & 2.3 \\
\hline 15 & DW18 09 & PCEA & -20.375 & -20.137 & 553 & 2.2 \\
\hline 14 & AW17 04 & NBG-17 & -20.625 & -20.387 & 548 & 2.2 \\
\hline 13 & FW15 07 & IG-430 & -20.875 & -20.636 & 542 & 2.1 \\
\hline 12 & EW14 07 & IG-110 & -21.125 & -20.885 & 535 & 2.0 \\
\hline 11 & CA11 01 & H-451 & -21.375 & -21.135 & 528 & 2.0 \\
\hline 10 & H472 & A3-3 & -21.625 & -21.383 & 520 & 1.9 \\
\hline 9 & J1 01 & HLM & -21.875 & -21.631 & 511 & 1.8 \\
\hline 8 & K1 01 & PGX & -22.125 & -21.880 & 501 & 1.8 \\
\hline 7 & L1 01 & PPEA & -22.375 & -22.128 & 490 & 1.7 \\
\hline 6 & M1-01 & NBG-25 & -22.625 & -22.377 & 478 & 1.6 \\
\hline 5 & TP 01 & 2114 & -22.875 & -22.626 & 464 & 1.6 \\
\hline 4 & P1-01 & PCIB & -23.125 & -22.875 & 449 & 1.5 \\
\hline 3 & RW1 02 & BAN & -23.375 & -23.124 & 432 & 1.4 \\
\hline 2 & CPB1 & HOPG CAN & -23.625 & -23.374 & 413 & 1.3 \\
\hline 1 & S1 01 & NBG-10 & -23.875 & -23.624 & 392 & 1.3 \\
\hline & & & & & & \\
\hline
\end{tabular}

